\title{
A Decade of Organs-on-a-Chip Emulating Human Physiology at the Microscale: A Critical Status Report on Progress in Toxicology and Pharmacology
}

\author{
Mario Rothbauer ${ }^{1,2,3, *}$, Barbara E.M. Bachmann ${ }^{1,2,4}{ }^{1}$, Christoph Eilenberger ${ }^{1,2}$, Sebastian R.A. Kratz ${ }^{1,2,5}$, \\ Sarah Spitz ${ }^{1,2}$, Gregor Höll ${ }^{1,2}$ and Peter Ertl 1,2,* \\ 1 Faculty of Technical Chemistry, Institute of Applied Synthetic Chemistry and Institute of Chemical \\ Technologies and Analytics, Vienna University of Technology, Getreidemarkt 9/163-164, 1060 Vienna, Austria; \\ barbara.bachmann@tuwien.ac.at (B.E.M.B.); christoph.eilenberger@tuwien.ac.at (C.E.); \\ s.kratz@em.uni-frankfurt.de (S.R.A.K.); sarah.spitz@tuwien.ac.at (S.S.); gregor.hoell@tuwien.ac.at (G.H.) \\ 2 Austrian Cluster for Tissue Regeneration, 1200 Vienna, Austria \\ 3 Karl Chiari Lab for Orthopaedic Biology, Department of Orthopedics and Trauma Surgery, \\ Medical University of Vienna, Währinger Gürtel 18-22, 1090 Vienna, Austria \\ 4 Ludwig Boltzmann Institute for Experimental and Clinical Traumatology, \\ Allgemeine Unfallversicherungsanstalt (AUVA) Research Centre, Donaueschingenstraße 13, \\ 1200 Vienna, Austria \\ 5 Drug Delivery and 3R-Models Group, Buchmann Institute for Molecular Life Sciences \& Institute for \\ Pharmaceutical Technology, Goethe University Frankfurt Am Main, 60438 Frankfurt, Germany \\ check for \\ * Correspondence: mario.rothbauer@meduniwien.ac.at (M.R.); peter.ertl@tuwien.ac.at (P.E.)
} updates

Citation: Rothbauer, M.; Bachmann, B.E.M.; Eilenberger, C.; Kratz, S.R.A.; Spitz, S.; Höll, G.; Ertl, P. A Decade of Organs-on-a-Chip Emulating Human Physiology at the Microscale: A Critical Status Report on Progress in Toxicology and Pharmacology. Micromachines 2021, 12, 470. https://doi.org/10.3390/ mi12050470

Academic Editor: Qasem Ramadan

Received: 31 March 2021

Accepted: 19 April 2021

Published: 21 April 2021

Publisher's Note: MDPI stays neutral with regard to jurisdictional claims in published maps and institutional affiliations.

Copyright: (c) 2021 by the authors. Licensee MDPI, Basel, Switzerland. This article is an open access article distributed under the terms and conditions of the Creative Commons Attribution (CC BY) license (https:// creativecommons.org/licenses/by/ $4.0 /)$.

\begin{abstract}
Organ-on-a-chip technology has the potential to accelerate pharmaceutical drug development, improve the clinical translation of basic research, and provide personalized intervention strategies. In the last decade, big pharma has engaged in many academic research cooperations to develop organ-on-a-chip systems for future drug discoveries. Although most organ-on-a-chip systems present proof-of-concept studies, miniaturized organ systems still need to demonstrate translational relevance and predictive power in clinical and pharmaceutical settings. This review explores whether microfluidic technology succeeded in paving the way for developing physiologically relevant human in vitro models for pharmacology and toxicology in biomedical research within the last decade. Individual organ-on-a-chip systems are discussed, focusing on relevant applications and highlighting their ability to tackle current challenges in pharmacological research.
\end{abstract}

Keywords: organs-on-a-chip; body-on-a-chip; micro-physiological systems; bioprinting; lung-on-achip; liver-on-a-chip; skin-on-a-chip; kidney-on-a-chip; heart-on-a-chip

\section{Introduction}

Over the last three decades, microfluidic systems have evolved from simple chemical sample handling tools to bioanalytical devices and sophisticated cell culture systems. Microfluidic technology builds on microfabrication techniques established within the semiconductor industry to manipulate fluids within micrometer-sized channels. The application of sophisticated microengineering techniques allows careful tailoring of microchannel design, geometry, and topography, leading to precise control over fluid behavior [1]. By translating these engineering techniques from microfluidic chemical reactors to cell-based microfluidic devices, novel biomedical research models can attain unprecedented control over cell behavior in vitro.

Cell-based microfluidic devices recapitulate essential organ functions by mimicking spatiotemporal cell architecture, heterogeneity, and dynamic tissue environments. Consequently, cell-based microfluidic devices are often termed micro-physiological organ-, multi-organ, or human body-on-a-chip systems. In 2016, the world economic forum named 
organs-on-a-chip models as one of the top 10 emerging technologies due to their prospective economic impact and ability to mimic physiologic organ functions in vitro [2]. The main advantage of integrating complex biology in microfluidic devices is microfluidic systems' inherent ability to control crucial tissue-specific parameters such as flow rates, temperature profiles, gradients, and biomechanical cues [3-9]. As a result, several microfluidic cell culture systems have been developed over the years to study the physiologic interplay between organs and tissues as well as the onset and progression of various diseases. The initial concept of recreating tissue and organ communication under controlled measurement conditions was introduced in 2004 by Albert Li and co-workers. They developed the 'integrated discrete multiple organ culture' (idMOC) for pharmacological and toxicological drug screenings based on a "well-in-well" principle in a microtiter plate format [10]. The idMOC system benefits from the constant exchange of soluble cues between different cell types, which strongly influences tissue and organ function in vitro. Building on these idMOC systems, Michael Shuler's and colleagues at Cornell University developed multicompartment cell culture systems incorporating acellular microfluidic channels to control flow rates, shear, load, and strain forces to simulate the human vasculature. These 'Micro Cell Culture Analogues' enabled, for the first time, indirect cell-to-cell communication via molecule exchange between individual organ compartments [11].

Nowadays, referred to as 'Human-on-a-Chip' and 'Body-on-a-Chip' systems, they incorporate a functioning circulatory system to supply tissue cultures with nutrients and drugs while simultaneously controlling fluid resident time within multiple organ cultures by adjusting the geometries of the micromachined culture compartments. Building on this pioneering work, next-generation organ-on-a-chip systems have integrated microvalves and micropumps, pioneered by Mathies, Maeda, and Quake groups, to precisely control mixing, shear force, and fluid velocities within the microfluidic channel network [12-14].

Organ-on-a-chip systems emulate organ functions by incorporating multiple cell types within a three-dimensional (3D) tissue microenvironment $[15,16]$. In addition to simulating the native cellular microenvironment by applying microfluidic engineering techniques, cell-based lab-on-chip systems allow the incorporation of biosensing solutions to enable on-chip analysis as an alternative to strictly endpoint-based analysis routinely employed in biomedical research [17]. As a result, organ-on-a-chip systems can reproducibly monitor human physiological and pathological processes via optical and electrical sensing strategies to identify dynamic cellular behavior with high structural resolution [18]. Organ-on-a-chip system design centers on three key parameters to mimic a physiologically relevant microniche: (1) the specific native tissue architecture, (2) incorporating dynamical stimulation, and (3) emulating spatiotemporal biochemical concentrations [19]. The precise control over geometrical characteristics allows arranging tissue cells according to nature's blueprint and has led to the establishment of functional vasculature [8,20], or placental [21,22] and bloodbrain barriers [23]. Furthermore, the human body's dynamic mechanical environment is recreated by repurposing pneumatic actuation principles originally designed to move fluid via the deformation of flexible membranes. In organ-on-a-chip systems, flexible membranes stretch cell layers to simulate rhythmic contraction or inflation in muscle [24-26], heart [27], lungs [28], and bone tissue [29]. Novel micro-physiological organ systems enable biomedical researchers to understand physiological organ-level functions, investigate deregulation during pathogenesis, and explore treatment and regeneration options [30].

Organ-on-a-chip systems can potentially improve target discovery and toxicity screening in drug development while also offering an opportunity to refine, reduce, and replace animal testing in preclinical trials [31]. The replacement of animal models in biomedical research not only resolves ethical issues associated with animal use but could also accelerate drug discovery while reducing costs (please see other comprehensive reviews for more details) [32-34]. In turn, accelerated drug pipelines offer the possibility to explore and evaluate new medical concepts, such as nanomedicine, efficiently [35,36]. As a new paradigm in medicinal nanotechnology, nanomedicine has recently gained attention as therapy in a broad spectrum of diseases [37]. Examples of commonly used materials range 
from lipids, phospholipids, polymers, and proteins to inorganic materials. Some of them, such as FDA-approved liposomes (e.g., Doxil ${ }^{\circledR}$ ) or nanoparticles (e.g., Abraxane ${ }^{\circledR}$ ), are already widely used for the clinical treatment of breast cancer [38]. In these pharmacological and toxicological areas, organ-on-a-chip technology offers a broad spectrum of techniques that can be influential in improving the outcome and predictiveness of in vitro screening technologies. However, the relevance of these microscale technologies for human physiology, disease, and pharmacology first need to be tested. As a consequence, this review summarizes and critically assesses recent advances in the field of organ-on-a-chip technology, including both single-organ as well as multi-organ models with a specific focus directed toward their applications in pharmacology and toxicology.

\section{Lung-on-a-Chip Systems: Biomechanically Improved Disease Models}

The respiratory system consists of a conducting zone (trachea, bronchi, bronchioles) from where inhaled air travels to the respiratory zone (alveolar ducts to alveoli sacs) for gas exchange [39]. Overall, the lung lobules are separated into segments that are individual functional units comprising a bronchus and an artery [40] (see Figure 1A). Pathologies of the lung and respiratory system range from asthma, chronic obstructive pulmonary disease (COPD), bronchitis, and lung cancer to cystic fibrosis [41]. Current preclinical models for human pulmonary diseases are either based on in vivo rodent models that can only mimic certain aspects of human pathologies [42,43], or on ex vivo lung tissue. Ex vivo approaches that use millimeter-thick lung slices of living lung tissue propose an intriguing alternative to current animal models by reflecting the lung's cellular architecture, structure, function [44], and airway contraction-relaxation dynamics, but these methods are limited by tissue availability [45]. Furthermore, explant cultures can only be tested for a limited experimental time window of days to weeks, which is a major problem for long-term investigation of chronic disease situations. Recent advances in stem cell technology, namely the possibility to induce pluripotent stem cells (iPSC) from somatic cells, allow the recreation of human living lung tissue and associated pathologies in vitro. Using patient-derived progenitor cells (e.g., from cystic fibrosis) [46-49], complex 3D lung spheroids and organoids can generate mature alveolar epithelium in the lab [50]. These in vitro models offer in vivo-like biological complexity but still lack basic biomechanical cues crucial for lung physiology. In contrast to such static in vitro lung models, lung-on-achip models can mimic breathing motions via stretchable membranes to incite epithelial differentiation and physiologic functionality [28]. Microfluidic lung models (shown in Figure $1 B, C$ ) incorporate a hydrogel matrix or a porous polymer membrane to mimic the basal membrane in the alveolar epithelium that is subsequently and rhythmically actuated to simulate breathing motions (see overview in Table 1).

The field of micro-physiological models for human lungs, known as 'lung-on-a-chip systems,' originated in 2010 when Huh et al. established one of the first biomimetic microfluidic lung models capable of exposing alveolar cells to dynamic stretching [28]. In their device, apical human alveolar epithelial cells, and basolateral microvascular endothelial cells are co-cultured on either side of a porous, flexible poly-dimethylsiloxane (PDMS) membrane to recapitulate an alveolar-capillary interface. By applying vacuum to pneumatic channels on either side of the membrane, the device rhythmically stretches the cell cultures to simulate breathing motions. This physiologic, dynamic environment results in higher magnitudes in transepithelial electrical resistance (TEER) values indicate improved barrier integrity than static culture conditions. The dynamically stimulated cell cultures exhibit in vivo-like physiological responses to E. coli nanoparticle exposure and simulate lung edema by reacting to interleukin-2 stimulation with increased barrier leakage. Moreover, the on-chip lung cultures can be used to simulate diseases, such as edema [51]. When adding interleukin 2 (IL-2) to the vascular compartment, the cell barrier started to leak liquid into the alveolar channel. Edema formation was even stronger under cyclic mechanical stretching, which demonstrates the importance of adding add biomechanical loading in a physiological in vitro model. To validate their model, the authors tested 
the inhibitory effect of transient receptor potential vanilloid 4 (TRPV4) anti-edema drug GSK2193874 to recover barrier integrity, which is similar to drug screening studies in animal models [52]. Additionally, other lung anatomies can be mimicked by varying cell types, as demonstrated in a small airway-on-chip model [53]. In the small airway-on-chip model, the cells respond with asthma and COPD-like phenotypes to interleukin stimulation. The authors demonstrated synergistic effects of lung endothelium and epithelium on cytokine secretion, identified new biomarkers of viral disease exacerbation (M-CSF) that is induced artificially with polyinosinic-polycytidylic acid (poly(I:C), and measured responses to anti-inflammatory compounds that inhibit cytokine-induced recruitment of circulating neutrophils under dynamic culture conditions. In addition to deciphering disease mechanisms in vitro, the small-airway-on-a-chip system can be connected to a device that generates cigarette smoke for alveolar epithelial exposure, leading to ciliary pathologies and COPDspecific molecular signatures [4].The most recent study on this small airway-on-a-chip model by Nawroth et al. [54] looked into rhinovirus-induced asthma exacerbation when infected with live human rhinovirus 16 (HRV16). In this particular study, the chip-based airway model recapitulated viral infection of asthmatic airway epithelium and neutrophil transepithelial migration, which was greatest when viral infection was combined with IL-13 treatment, while treatment with a CXCR2 antagonist reduced neutrophil diapedesis, concluding that IL-13 plays an inhibitory role in immune response modulation against rhinovirus infection. This basic principle can potentially be exploited for drug screening studies on immunomodulatory drugs, such as Janus Kinase (JAK) inhibitors. Furthermore, this micro-engineered airway lung-on-chip example provides a human-relevant model to study the system behind viral-induced asthma exacerbation. The model shows that IL-13 may impair the hosts' ability to mount an appropriate and coordinated immune response to rhinovirus infection [55].

Another lung-on-a-chip system based on flexible porous PDMS membranes was established by Stucki et al., who integrated a bio-inspired respiration mechanism to investigate the mechanical stretching effects on the air-blood barrier within the lung [56]. In contrast to the lung-on-a-chip systems developed by Huh et al. that stretch the cells parallel to the cell layer, this device mimics diaphragm motions by deflecting a circular membrane perpendicular to the cell surface. However, while integrating a physiologic 3D breathing motion is intriguing, varieties in presented data and cell-type hamper a direct comparison of the devices and cellular reaction. These difficulties in comparing lung-on-chip cultures demonstrate that novel devices need to integrate in-line sensing methods to monitor breathing motions and assess barrier integrity as an epithelial functionality indicator. For example, Mermoud et al. integrate a PCB-based micro-impedance tomography sensor that accurately monitors membrane deflection and tracks lung barrier integrity [57]. This technology significantly improves in-line monitoring of cell barrier integrity compared to conventional tetra-polar TEER measurements routinely employed in other lung-on-a-chip systems [58-60].

In addition to the epithelial layer's mechanical actuation, fluid perfusion and shear stress are essential biomechanical parameters for lung physiology. Lung-on-a-chip devices emulate blood flow within alveolar capillaries by perfusing fluid through endothelial-cell lined channels. This type of fluid perfusion significantly enhances physiologic endothelial cell responses and increases intracellular surfactant-containing laminar body formation and surfactant secretion in type II alveolar epithelial cells [61]. In addition to enhancing physiologic cellular phenotypes, microfluidic device perfusion can be used to perfuse whole blood and investigate blood clot formation in pulmonary embolism [62]. Pulmonary thrombus formation within a primary alveolus-on-a-chip system is stimulated by lipopolysaccharides and endotoxins, while a prospective antithrombotic therapeutic agent to treat pulmonary thrombosis prevents blood clotting. Reconstituting the dynamic microenvironment of the blood vessel-tissue interface via perfusion is imperative for whole blood perfusion and investigation of circulatory cell migration into the alveolar epithelium during inflammation under physiologic conditions [63]. To enable the use as a dynamic, perfused Transwell 
system, lung-on-a-chip systems need to include porous membranes for co-culturing epithelial and endothelial cells. The integration of flexible and biocompatible alternatives to PDMS as culture substrates is inherently challenging but needs to be achieved to study drug responses reliably. For example, Yang et al. introduced an electrospun poly(lactic-coglycolic acid) nanofiber membrane in their lung-on-a-chip microdevice to co-culture airway epithelial and endothelial cells for drug screening [64] and Humayun et al. suspended hydrogels as a scaffold to spatially align different cell types within a microfluidic lung airway-on-a-chip [65]. The main advantage of using a physiological relevant hydrogel membrane is recapitulating the interface of airway epithelial cells and airway smooth muscle cells. Furthermore, Zuchowska et al. established a less frequently used culture technique with their 3D lung-on-a-chip model based on cancer and healthy lung spheroids to evaluate the anti-cancer activity of photodynamic therapy procedures using prodrug 5-aminolevulinic acid [66]. Overall, lung-on-a-chip devices succeed in mimicking the dynamic lung environment by including physiologic stretching motions and vascular perfusion and reward physiologic cellular behavior as a result. However, the use of these models in preclinical drug development demands the introduction of in-line sensing strategies and the replacement of hydrophobic molecule-adsorbing PDMS to permit viable medium-throughput and high-throughput candidate screening.

A
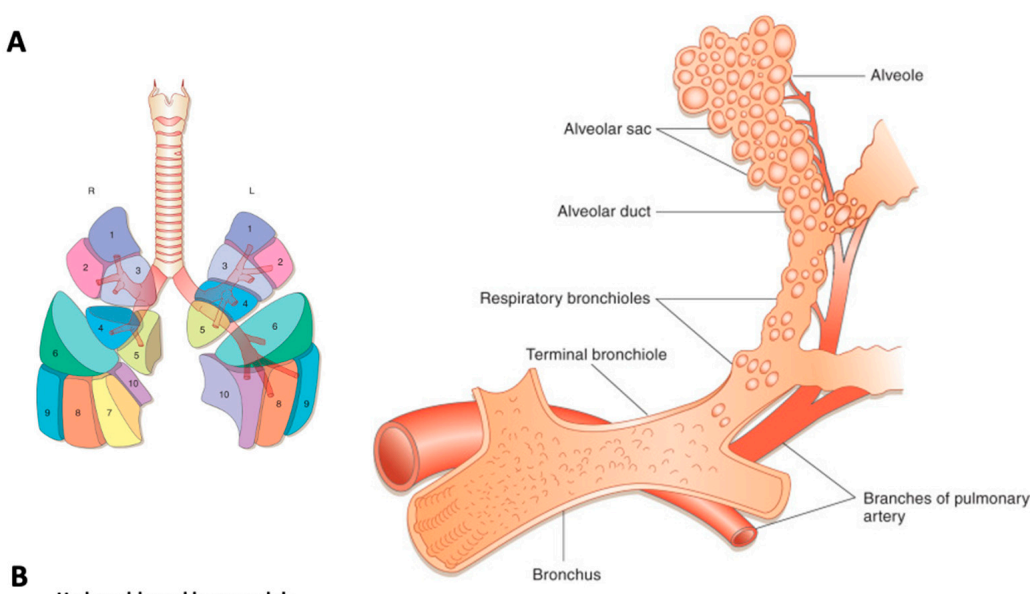

B Hydrogel-based lung models $\stackrel{z}{\longrightarrow} x$
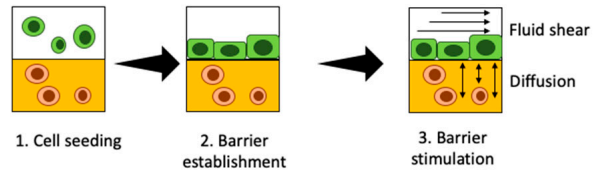

(1) Lung epithelial cell Secondary cell type

C

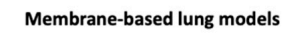

$\stackrel{2}{\rightarrow} x$

Membrane-based lung models
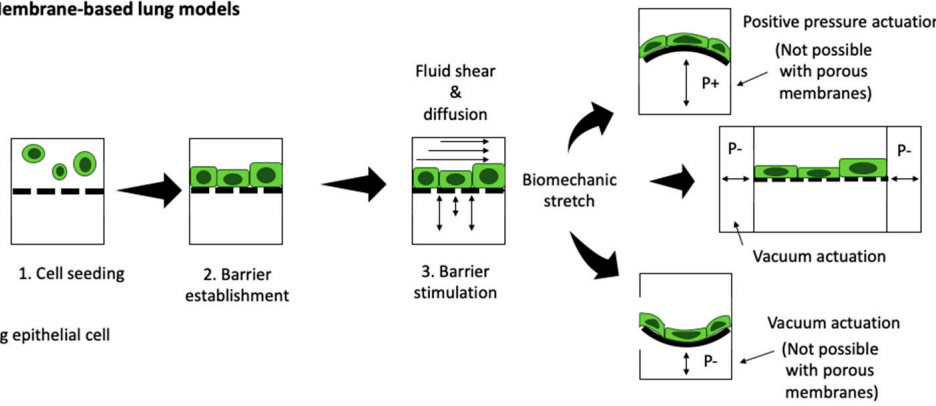

(1) Lung epithelial cell stimulation

Figure 1. Overview over (A) functional lung anatomy (Reproduced from Reference [40] with permissions), as well as biochip approaches including (B) hydrogel-based lung-on-a-chip and (C) membrane-based lung-on-a-chip with different barrier stimulation and actuation principles. (positive pressure $\mathrm{P}+$; negative pressure $\mathrm{P}$ ). 


\section{Skin-on-a-Chip Systems: Combined Epidermis Full Skin Thickness Models}

As the largest organ of the integumentary system, the skin, built up of several layers of ectodermal tissue, provides the first line of defense against potentially harmful external factors. While ex vivo models of the skin provide a well-established platform for substance testing due to their intrinsic ability to present the hierarchical organization of this barrier, they are limited by both tissue availability and short-term viability. In an effort to overcome these limitations, a variety of companies, including Episkin (Lyon, France), MatTek (Ashland, MA, USA), CellSystems (Troisdorf, Germany), Henkel AG (Dusseldorf, Germany), StratiCELL (Gembloux, Belgium), J-TEC (Aichi, Japan), and Biosolution KO (Seoul, Korea) have invested in the development of commercial in vitro epidermis as well as full-skin models, primarily based on the traditional Transwell set-ups. In addition, significant progress has been made in developing microfluidic skin-on-a-chip models by improving the static Transwell assembly (see overview in Table 2). For instance, Alexander et al. developed a skin-on-a-chip device capable of monitoring both TEER and extracellular acidification rates in an air-liquid interface model [67]. Using this device, the authors were able to detect the impact of sodium dodecyl sulfate in a co-culture of murine fibroblasts (L929) and commercial EpiDerm ${ }^{\mathrm{TM}}$ RhE 3D keratinocyte-derived 3D tissues. In their upscaled approach, Sriram et al. developed a mass-producible four-layer platform based on the polymer polymethyl methacrylate (PMMA) to establish skin equivalents with minimal hydrogel shrinkage [68]. After the dermal equivalent based on PEG-fibrin-embedded fibroblasts was established, at day 4 , a co-culture with $N$ /TERT- 1 keratinocytes were initiated at the apical side before switching the culture to air-liquid-interface cultivation. While TEER measurements confirmed improved barrier integrity, immunohistochemical analysis revealed a more pronounced emulation of the epidermal tissue architecture when compared to static Transwell systems. In order to model the epidermal and dermal tissue more accurately, Mori et al. developed a skin-on-a-chip system containing perfusable vascular channels as well as an air-liquid-interface [69]. To that end, endothelial cells (HUVECs) were seeded into a microchannel formed within a fibroblast (NHDFs) embedding collagen hydrogel. After seeding normal human epidermal keratinocytes (NHEKs) on top of the hydrogel construct to create a skin-air-interface in the second step, the uptake of the compound isosorbide dinitrate and caffeine were evaluated. By employing a perfused microfluidic model, Lee at al. demonstrated the importance of fluid flow on the viability of a vascularized 3D skin model exhibiting dermal and epidermal features [70]. Moreover, using a skin-on-a-chip platform, Alberti et al. could confirm similar diffusion behaviors of caffeine, salicylic acid, and testosterone upon comparison to an in vitro skin permeation assay based on a static Franz diffusion cell loaded with similar organotypic skin equivalents while reducing sample variation by half [71].

To facilitate the handling of perfused microfluidic devices, Song et al. opted for the development of a pumpless passive flow device to co-culture fibroblasts and $\mathrm{HaCaT}$ keratinocytes. While the model was validated by assessing matrix remodeling via the expression of the extracellular matrix (ECM) components Collagen IV, Keratin X, and fibronectin, the study could also link collagen sources to keratinocyte differentiation capacity [72]. In their passively driven device, Abaci et al. established an air-skin-interface model for the monitoring of cutaneous drug uptake [73]. Herein, the authors revealed the direct toxic effects mediated by the chemotherapeutic drug doxorubicin on keratinocyte proliferation and differentiation.

Wufuer et al. induced a TNF- $\alpha$-mediated edema in their skin-on-a-chip model to evaluate dexamethasone as a treatment option for the swelling of both the epidermis and dermis [74]. Consisting of three stacked compartments with each separated by a porous PET membrane, this device comprises an epidermal, dermal, and vascular layer to assess drug translocation. An improved micro-physiological immune-competent $\mathrm{HaCaT}$ keratinocyte-based skin model capable of modeling human skin allergy responses was introduced by Ramadan et al. who employed integrated TEER measurements to assess the impact of the immune system on the barrier integrity of the skin construct following 
exposure to lipopolysaccharides as well as UV light [75]. Environmental factors, such as UVB irradiation, are particularly interesting because skin irradiation is believed to induce cutaneous barrier deterioration in skin xenografts as well as skin equivalent models by downregulating tight junctions (claudin-4) [76]. Another technological leap forward includes the integration of the hypodermis featuring white adipose tissue since adipose tissue residing beneath the dermis can act as an uptake reservoir for hydrophobic pharmacologically substances [77]. Loskill et al. investigated the properties of white adipose tissue in a micro-physiological system using preadipocytes differentiated on a chip [78]. This adipose-tissue-on-a-chip allowed for the incorporation of features specific to adipose tissue, such as collagen secretion and lipid droplet formation. Only the on-chip combination of the epidermis with vascularized full thickness skin, including adipose tissue, will be able to provide a translatable and physiologically relevant alternative model for pharmaceutical and pharmacokinetic uptake studies. Furthermore, future on-chip skin models will need to account for the immune system as well as the nervous system to create a miniaturized model that resembles physiological skin [79]. From an anatomical viewpoint, skin-on-achip systems also need to consider skin appendages, i.e., follicles and glands, which can be grown with organoid technology [80], as demonstrated by Lee et al. These structures are vital for control of temperature, fluids, and external stress. Furthermore, similar to the lung-on-a-chip strategy, biomechanical cyclic strain should also be considered for future models as loading is vital for skin homeostasis while overuse can stimulate fibrosis pathways [81,82].

\section{Liver-on-a-Chip: Valid Models for Pharmaceutical Screening}

The liver is the largest internal human organ and is involved in drug metabolism (first pass effect) and detoxification as well as other metabolic functions that regulate blood glucose levels, bile synthesis, and the production of various plasma proteins, such as albumin. Anatomically, the liver is built up by liver acini, which are the functional units of the liver comprising liver sinusoids that are connected to a complex network system of hepatic artery, portal vein, central vein, and bile ducts [83] (see Figure 2A). Due to its overall importance in drug metabolism, the liver is a major focus of pharmaceutical research [84]. The liver, as a vital organ, plays an essential role in protein synthesis and xenobiotic metabolism and exhibits a high degree of regenerative capacity. However, drugs, toxins, viral infections, cancer, and even traumatic injuries can still result in permanent tissue damage and liver function impairment, which will eventually lead to end-stage liver disease or acute liver failure $[85,86]$. To date, human liver slices as well as rodent animal models have been widely used for drug screening and toxicity testing in pharmaceutical research as well as models for pathophysiological studies on non-alcoholic- and alcoholic fatty liver disease (NAFLD/ALD) [87-90].

As a result of the limited availability of human tissue samples and the ambiguous findings from animal models that often do not translate well to humans [91], a number of chip-based cellular and acellular liver models using a minimal number of human cells at minimal tissue-like architectural features have been developed in recent years, as outlined in Figure 2 (see overview in Table 3). The four basic approaches depicted in Figure $2 \mathrm{~B}$ can be found to recapitulate liver-function using liver-on-a-chip systems for a range of organotypic complexities. To further improve biomimetic architecture and organotypic function, hepatocytes can be co-cultured with endothelial and other support cells (i.e., Kupffer or stellate cells) as 2D monolayers on microchannels and membranes, multi-layered 2.5 D co-cultures on membranes and interfaces as well as multi-cellular spheroids (MCS) and heterotypic hydrogel-embedded multi-co-cultures, respectively, to recapitulate various degrees of cellular functions and tissue architectures found in vivo in liver sinusoids (see Figure 2B). 
A

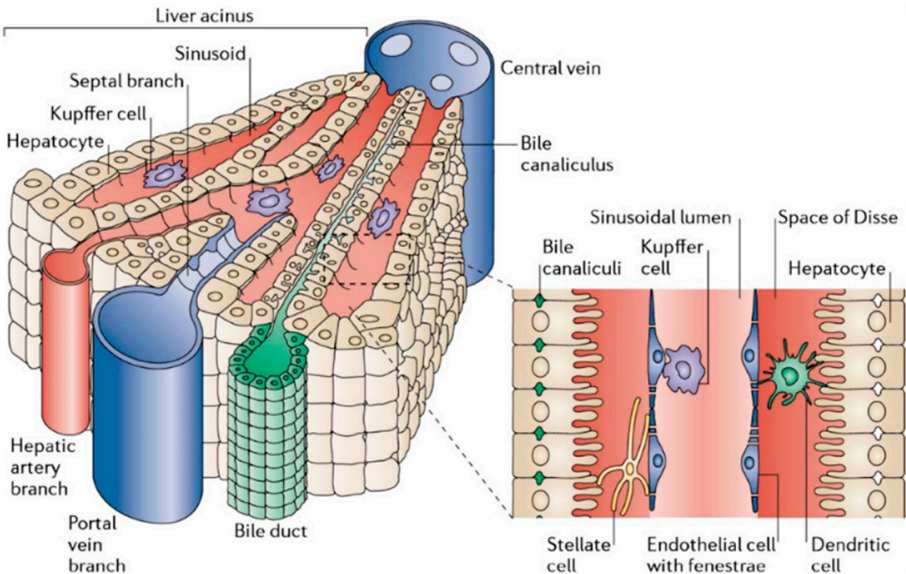

B

Liver biotransformation strategies

Liver microsomes In hydrogel reservoir
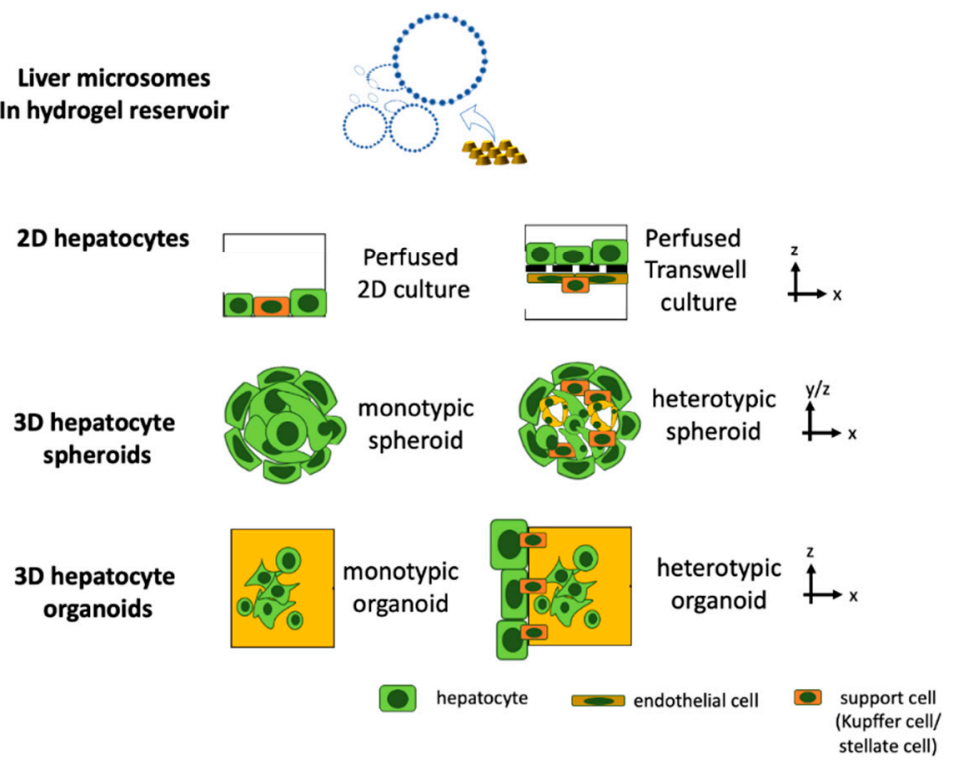

Figure 2. (A) Structure of liver acini and sinusoids. (Reproduced from Reference [83] with permissions of Elsevier 2021). (B) Biotransformation strategies on-chip mimicking liver metabolism using acellular microsome or hepatocyte-based approaches.

A common and important physiological parameter of in vitro liver systems for pharmacological studies is defined by the metabolic cytochrome P450 activity of hepatocytes [92]. For instance, reaction kinetics of P450 enzymes encapsulated within liver microsomes generated from photosensitive of polyethylene glycol diacrylate (PEG-DA) gels were used by Lee et al. to simulate the liver function without the use of hepatocytes [93]. This study demonstrated that acellular substitutes can be employed as a simple model of the liver metabolism for pharmaceutical research on a chip. However, twodimensional (2D) hepatocyte monolayers and 3D liver constructs were widely used as in vitro liver models for drug screening applications and disease mechanism studies. An important premise of any liver model for drug screening and pathophysiological studies is the establishment of a well-organized liver microtissue that recapitulates both the structural, physiological features and liver-specific functions of the native liver through the co-culture with non-parenchymal cells and the re-creation of the liver ultrastructure, using micromachining techniques [94]. The key aspect of liver-on-a-chip technologies is the implementation of dynamic fluidic flow conditions to generate a biomechanical, 
organotypic culture microenvironment. A number of studies based on monolayer cultures of rat and human hepatocytes as well as those using 3D liver spheroids based on HepG2 and iPSC-derived hepatocytes have shown that the presence of fluid flow ensures reliable delivery of important soluble factors in a controlled manner, resulting in improved viability and enzymatic activities (e.g., CYP1A1, CYP1A2 and CYP3A4) [95,96]. For instance, using a three-dimensional liver-on-a-chip system, Lee et al. demonstrated the importance of supporting hepatic stellate cells (HSCs) to maintain hepatocyte spheroids, especially the formation of tight cell-cell contacts, thereby, significantly improving liver-specific function and resulting in enhancing cytochrome P450 activity [97]. Another important application of hepatic models includes drug screening and chemical-safety testing. These approaches require functional matured hepatocytes and human pluripotent stem cell (hPSCs) technology that is considered one alternative to provide robust and highly pure hepatic clusters. For instance, Kamei et al. developed a liver-on-a-chip platform using mature and functional hepatocyte-like cells derived from hPSCs [98], to create a 3D culture environment in which hepatocyte-like cells exhibited increased expression of hepatic maturation markers and cytochrome P450. The improved cultivation conditions led to a significantly elevated drug uptake/excretion capabilities above $90 \%$, thus, highlighting the benefits of using human iPSC-derived hepatocytes as a substitute for immortalized as well as primary hepatocytes in drug screening and chemical safety testing. To model alcoholic liver disease, Deng et al. simulated liver sinusoid function by co-culturing HepG2 hepatocytes with LX-2 stellate cells, EAhy926 endothelial cells, and U937-derived Kupffer cells in a multi-layered double-membrane liver-on-a-chip system that displayed improved viability and increased urea and albumin levels [99]. The authors also demonstrated that exposure to alcohol damages the tight junctions of hepatocytes, reduces the release of $\mathrm{NO}$ of endothelial cells, and stimulates stellate cell proliferation. A similar study confirmed the validity of this complex on-chip co-culture model by using human primary hepatocytes instead of cell lines [100]. Another example of the on-chip co-culture system includes primary human hepatocytes and liver sinusoidal endothelial cells (LSECs) with stellate and Kupffer cells. Here, Li et al. investigated the role of zonation in hepatic physiology, hepatotoxicity, and progression of liver diseases using their liver acinus model. The endothelial compartment lined with human LSECs recapitulated immunologic functions within the liver sinusoid and promoted polymorphonuclear leukocytes' adhesion and transmigration upon activation. Furthermore, zonation-specific differential oxygen gradients lowered hepatic mitochondrial activity and hepatic steatosis but triggered increased $\alpha$-SMA expression and proliferation of stellate cells at $4 \%$ oxygen [101]. Another sinusoid-on-a-chip system was developed by Kang et al. introducing a less complex, animal-derived liver model to analyze viral replication for hepatitis B virus (HBV) [102].

In a different study, a liver-resembling microfluidic device called 'Exoliver culture' showed not only the main characteristics of the liver sinusoid including cellular architecture, biodynamic angiocrine stimulation, and parenchymal zonation, but also responded differently to acute treatment with known hepatotoxic drugs than those seen in conventional culture platforms [103]. An acute toxic insult of $100 \mu \mathrm{M}$ troglitazone did not show any effect on the Exoliver platform even though $\mathrm{IC}_{50}$ values for troglitazone toxicitiy is around $10 \mu \mathrm{M}$ [104]. Considering that the clinical $\mathrm{c}_{\max }$ values [105] for drug-induced liver injury (DILI) of troglitazone are around $5 \mu \mathrm{M}$, the Exoliver platform shows low sensitivity with lack of increase of soluble keratin 18 levels compared to spheroidal human liver models that are more sensitive for drug assessment in vitro $\left(\mathrm{IC}_{50} 5-10 \mu \mathrm{M}\right)$. Furthermore, even though a dual species approach was initially investigated for the liver phenotype, the drug screening efforts were performed only for human liver biochips. However, species-related differences are very strong when comparing the liver toxicity model, i.e., of human and rat origin. In a cross-species study comparing humans with rat and dog models, Jang et al. [106] investigated organotypic liver function as a drug screening and disease modelling platform to investigate species-specific responses. For instance, a human liver-on-a-chip could predict dose-dependent lipid accumulation, albumin reduction, and release of liver injury markers 
as an indicator for steatosis caused by fialuridine (FIAU). Neither a rat liver-on-a-chip nor a rat animal model could have predicted species differences in steatosis because such disease mechanisms require human or humanized models. Furthermore, this study shows that liver-on-a-chip technology should be considered complimentary technology to investigate other aspects of toxicology including the formation and effect of reactive metabolites in DILI at different architectural levels (i.e., cell as well as tissue context) to fill the knowledge gap between dynamic tissue responses and clinical patient pathologies. In addition, using the proposed cross-species approach, a basic pre-screening can identify a reactive and predictive system for more in-depth in vivo tests on a case-to-case basis (e.g., wildtype or humanized rat strain, etc.).

Even though liver-on-a-chip platforms are organotypic models to recapitulate liver functions using various cell types and co-culture techniques for basic science, these biomimetic systems still lack scalability for high-throughput experimental setups as the biochips only feature one or two individual liver units per chip. Combining protocols for generating liver-on-a-chip systems with more high-throughput technologies, such as the Mimetas OrganoPlate ${ }^{\circledR}$ or other microtiter formats, would increase the relevance of biomimetic liver modeling in vitro for drug and toxicity screening, which is clearly one major challenge for a broad application of such liver microsystems. Since pre-screening as well as high-content analysis do not require extensive throughput, liver-on-a-chip technology should be seen as a valuable 'gap filler' to improve the molecular understanding of the tissue response prior to animal models and clinical trials. The particular impact of how liver compartments change the pharmacological and metabolic predictiveness of multi-organ-ona-chip or body-on-a-chip systems will be reviewed later on Section 10. Multi-organ on-chip models show combined tissue models to screen drug-drug interactions, pharmacokinetics, and pharmacodynamics.

\section{Kidney-on-a-Chip: Evaluating Nephrotoxicity and Drug Efficacy}

The kidney plays a major role in maintaining homeostasis of the internal circulation. It regulates blood pressure, maintains a physiological $\mathrm{pH}$, retains essential nutrients, and eliminates waste molecules, including drugs and drug metabolites. To this end, the kidney receives a large cardiac output volume, has a high metabolic turnover rate, shows extended concentrating abilities, and is capable of efficiently trafficking compounds, which may increase sensitivity to drug-induced adverse effects at the kidney. Acute kidney injury is observed in a clinical setting, where $20 \%$ of all acute kidney injury cases are caused by kidney toxic drugs [107], strongly suggesting that current drug toxicity evaluation procedures need to be improved [108]. Kidney dysfunction resulting from drug side effects remains an important issue to consider in the drug development process. It is important to point out that traditional in vivo animal experiments are particularly limited with respect to evaluating drug efficacy and nephrotoxicity because of the apparent discrepancies in drug pharmacokinetics and pharmacodynamics between humans and animals. Recently, several types of human kidney-on-a-chip systems have been developed that reflect the microenvironment of the kidney tubule and have shown similarity to in vivo results of drug nephrotoxicity. Using kidney-on-a-chip systems, investigators can measure and evaluate various drug-induced biological responses [109], thus, showing potential advances in disease modeling and drug lead optimization studies (see overview in Table 4). Some bioengineering challenges, however, remain and are mainly concerned with reconstructing the complex architecture, cellular make-up, and matrix composition necessary to model kidney function at an organotypic level. This highly complex process starts at the proper exchange rate during glomerular filtration, followed by tubular secretion and reabsorption, which are all critical in human electrolyte regulation, toxin and metabolite excretion, and acid/base homeostasis [110]. Any alterations of these processes can result in a high incidence of tubular exposure to concentrated drugs and toxins, leading to kidney injury. In terms of structural complexity, the renal tubular system consists of three major structural components: the tubular lumen, the vascular lumen, and a thin 
layer of a basement membrane separating the luminal spaces, surrounded by the ECM. Furthermore, it is technically challenging to re-engineer the close alignment of vascular and tubular compartments necessary to model solute transfer across the renal tubular exchange interface where three major resident cell types, fenestrated endothelial cells, specialized epithelial cells, and interstitial perivascular cells are present [111]. To address these bioengineering challenges, Rayner et al. created a tunable human renal vascular-tubular unit formed entirely in collagen hydrogel [112]. Vascular and tubular lumens were assembled against a solute-permeable and mechanically robust collagen membrane and seeded with human kidney microvascular or epithelial cells. These cells gradually remodeled and condensed the collagen membrane to a few micrometers thickness, resembling a native basement membrane, while still maintaining sufficient integrity to support blood perfusion through the vascular lumen. Additionally, kidney-specific function was demonstrated including selective reabsorption of albumin and glucose.

Other kidney-on-a-chip devices incorporate organoids under flow using millifluidic systems to expand the endogenous pool of endothelial progenitor cells and to generate vascular networks with perfusable lumens surrounded by mural cells [113]. Vascularized kidney organoids cultured under flow exhibited, to a greater extent, mature podocyte and tubular compartments with enhanced cellular polarity and adult gene expression compared to static controls. The ability to induce substantial vascularization and morphological maturation of kidney organoids in vitro under flow opens new avenues for studies of kidney development, disease, and regeneration. An aspect that is commonly overlooked is that chemical compounds are also excreted through the kidney and/or biliary tract, thus, influencing drug concentrations within the body. To account for this effect, Kim et al. reported external fluid pumping mechanisms to recreate two types of pharmacokinetic profiles corresponding to either bolus injection or continuous infusion [114]. Nephrotoxicity testing of the antibiotic gentamicin revealed that continuous infusion reduced nephrotoxicity, and prolonged exposure to gentamicin disrupts cell-cell junctions, increased membrane permeability, and decreased cell viability. These results underline the benefits of using microfluidic cell culture models for pharmacokinetics and toxicity studies. In another nephrotoxicity study, a microtiter-plate-based microfluidic 3D proximal tubule on-a-chip was established with renal proximal tubular epithelial cells grown as tubules against an ECM. Exposure to the nephrotoxic, anti-cancer drug cisplatin showed a dose-dependent disruption of the epithelial barrier, a decrease in viability, an increase in effluent lactate dehydrogenase (LDH) activity, and changes in expression of tight-junction markers and inhibition of the crucial drug efflux pumps as $p$-glycoprotein ( $p$-gp) and multi-drug resistance protein (MRP) [115].

The glomerulus plays a central role in regulating the filtration of molecules across the renal barrier, whereas small molecules and water pass through the barrier. Conventional kidney systems have a limited ability to evaluate glomerular function, making them unsuitable for nephropathy studies on exposure to various environmental toxins. Li et al. established a kidney-on-a-chip model that facilitates cadmium-induced renal toxicity assessment in a physiologically relevant manner [116]. The toxic metal cadmium, which is a common environmental pollutant, poses a significant health risk to humans and, consequently, a major public health concern. As a representative study of the barrier function, its permeability to different molecules was characterized and quantified. The data support the appearance of pathological changes that are present in glomerular diseases in vivo under cadmium exposure, such as proteinuria. The culture and collection channels represent the capillary and the glomerular capsule sides of the glomerular filtration barrier, respectively. Isolated primary rat glomerular endothelial cells were cultured on the side surface of the middle gel channel to model the selective permeability of the renal barrier. Cadmium induced significant cytotoxicity and disrupted the expression of tight junction protein ZO-1 in a dose-dependent manner and increased the permeability of the endothelial layer to large molecules known as immunoglobulin $\mathrm{G}$ and albumin. These results facilitate the understanding of the underlying mechanism of kidney dysfunction and glomerular 
disease. Huang et al. showed that co-culture of adipose-derived stem cells (ASCs / AdMSCs) as well as kidney epithelial cells impact barrier height and also tight junction formation, resembling a condition closer to in vivo kidney tissue [117].

\section{Heart-on-a-Chip: Identifying Beneficial and Adverse Effects of Drugs in Health and Disease}

The heart's biomechanical environment, structural complexity, and exposure to dynamic stimuli play a critical role in maintaining cardiac physiological functions. Microfluidic in vitro platforms offer the opportunity to precisely control each of these factors, enabling us to study cardiac physiology and a range of pathologies such as myocardial infarction, arrhythmia, or cardiomyopathy [118] (see overview in Table 5). However, due to the high morbidity of heart diseases and common adverse effects of medication, the heart is an important target tissue for any drug development and interaction study. In other words, more predictive cardiac models will not only foster the identification of novel therapeutic strategies, but also help to screen off-target cardiotoxic adverse effects [119,120]. For instance, Ellis et al. presented a perfused myocardium-on-chip system consisting of spatially controlled co-cultures of human hiPSCs derived myocardial cells (iCMs) and hiPSC derived endothelial cells (iECs) from the same patient, thus, paving the way for personalized medicine [121]. This system enabled the reproduction of microvasculature (with iECs) and cardiac muscle (with iECs and iCMs) of the human myocardium. To assess the effect of ECM on the cardiotoxicity of isoproterenol on cardiomyocytes, Tomecka et al. performed a comparative analysis between (i) 2D-monolayer cultures and (ii) 3D-hydrogel models on a single chip platform [122]. Precise spatial orientation within a scaffold was accomplished by Zhang et al. who utilized 3D bioprinting to create a vascularized myocardium on-chip. Here, human umbilical vein endothelial cells (HUVECs) were printed into a scaffold and rat cardiomyocytes seeded on top to form a myocardium, which showed synchronous and spontaneous beating patterns. Investigation of a cardiotoxic substance (doxorubicin) was conducted by combining the device with a perfusion bioreactor [123]. Aside from the choice of cell types, which are the culture method and architectural considerations described above, electrical and mechanical stimulation constitutes another key parameter in establishing functional cardiac models [124,125]. As an example, Marsano et al. developed an organ-on-a-chip system with improved cardiac cell differentiation after applying mechanical stimuli (e.g., uniaxial cyclic strain) via pneumatic actuation on 3D cell-laden hydrogels confined by hanging posts. The stimulated functional microengineered cardiac tissues ( $\mu \mathrm{ECTs}$ ) displayed superior differentiation and better cell-to-cell coupling, which were analyzed electrically and mechanically. The devices' potential for drug testing applications was demonstrated using isoprenaline, which were 100-times lower concentration in the actuated microtissues (e.g., $1 \mathrm{nM}$ ), showed similar toxic responses that are otherwise seen at $100 \mathrm{nM}$ using embryonic cells [126]. Moreover, Chan et al. combined myocytes and cardiac fibroblasts with transfected optogenetic embryoid kidney cells expressing channelrhodopsin-2, channelrhodopsin-16, and channelrhodopsin17 that activates a light gated ion channel to forward the optical signal to the cardiac cells. Consequently, the muscle strip can be activated by blue light illumination similar to a pacemaker. This non-invasive strategy is able to activate and modulate muscle movements by blue light and it replaces mechanical or electrical stimulation of muscle cells [25]. To increase throughput, Hansen et al. established a multiplexed device capable of performing 24 heart-on-a-chip experiments in parallel using neonatal rat heart cells. A commercially available well plate combined with PDMS pillars allowed the measurement of beating rates and optical analysis of pillar deflection. The drug screening potential of the device was demonstrated by detecting increased relaxation time after the addition of clinicalrelevant blockers/drugs (chromanol, quinidine, erythromycin), whereas doxorubicin led to a decrease in the contraction force [127].

Monitoring heart functions using on-chip and off-chip sensing strategies constitutes a major advantage of organ-on-a-chip technology over standard in vitro systems. For instance, Ahn et al. showed the formation and analysis of cardiac tissues grown around 
muscle-inspired nanofibers using cantilevers. The movement of the cantilevers could be correlated to the contractility of the tissues to investigate effects of $\mathrm{TiO}_{2}$ and $\mathrm{Ag}$ nanoparticles [128]. A reusable device presented by Agarwal et al. is based on muscular, thin film technology coupled to a microfluidic channel for high throughput drug testing. Cardiac cells were seeded on one side of PDMS cantilevers and contraction was monitored, providing information about contractile responses. Here, microfluidic channels act as inlets/outlets for drugs, as shown with isoproterenol, allowing evaluation of dose-response relationships on cardiac cells using an autoclavable and cost-efficient testing system [129]. Using a multi-material 3D printing approach, a micro-physiological device was fabricated by Lind et al. to monitor cardiac activity based on a continuous electronic readout of contractile stress using multiple laminar cardiac micro-tissues derived from neonatal rat ventricular myocytes (NRVMs) and human-induced pluripotent stem cell-derived cardiomyocytes (hiPS-CMs). By using multilayered cantilevers including a base layer, embedded strain sensors, and a tissue guiding layer, it became possible to observe cardiac activity (contractile stress) of self-assembled micro physio-mimetic laminar tissues [130]. The system was validated by measuring the increased cardiac activity when isoproterenol was administered to the microsystem. Next, Stancescu et al. showed a combination of electrical and contractile activity measurements, where human stem cell-derived cardiomyocytes were cultivated as a 2D monolayer and a multi-electrode array allowed analysis of the beat rate, conduction velocity, and action potential length, whereas cantilevers allowed the contractile force analysis. Key drugs used in clinical studies (sotalol, norepinephrine, and verapamil) were tested with the device and the outcomes were in agreement with clinical data [131]. Similar to microelectrode arrays (MEAs), high speed impedance measurements of cardiac tissues provide information about their mechanical contraction status. Zhang et al. presented a platform with quartz substrate and gold electrodes, which acquires the impedance data and can be used to investigate cardiotoxicity and drug efficacy of the drugs verapamil and doxorubicin [132]. This generation of heart-on-a-chip systems was followed by multi-tissue and multi-organ models that included vascular barriers as well as bystander tissues, such as the liver, due to its high metabolic conversion activity of pro-drugs and pro-toxins to toxic metabolites.

\section{Vasculature-on-a-Chip: Vascular Barrier Transport and Anti-Vasculogenic Drug Screening}

Two vascular systems, known as the cardiovascular and the lymphatic system, provide the human body with nutrients and remove waste products. The cardiovascular system transports oxygenated blood, nutrients, and immune cells to every organ and tissue in the body via arteries, arterioles, and a fine interwoven mesh of capillaries. In contrast, the lymphatic system collects excess fluid expelled from the cardiovascular system by shear forces and recirculates it through the lymph nodes for immune control back to the cardiovascular system via passive-pumping motions [133]. Consequently, both vascular systems play an integral part in the absorption, distribution, and excretion of nutrients, drugs, and other compounds [134]. Irrespective of the type of vasculature, vessels are comprised of an inner endothelial cell barrier, controlling cells and molecule passage, and a stabilizing outer layer of pericytes or smooth muscle cells. New vasculature is either formed by de novo vascularization from single progenitor cells or by angiogenesis by sprouting from the existing vasculature [135]. Traditionally, vascular cells have been studied using monolayers in microtiter plates and Transwell cultures or pseudo-capillary structures on hydrogels, simplifying the models to a point where the translation to a human body becomes questionable due to loss of organotypic phenotype and genotype. Organ-on-a-chip technology provides the opportunity to engineer an in vivo-like cellular microenvironment tailored to vascular structures' needs, including physiological flow, control of direct and indirect cell-cell communication, and ECM-like hydrogel scaffolds (see overview in Table 7) [136,137]. Organ-on-a-chip models for vascular biology can be divided into two approaches, as shown in Figure 3A,B. Firstly, vessel generation by microfluidic-assisted methods, such as for sacrificial molding and, second, by cell self- 
assembly of vascular structures through vasculo-genesis or angiogenesis from individual cells [138]. Microfluidic-assisted methods for on-chip microvessel generation rely on providing a preformed structural architecture of vessels, either made from hydrogels or the microchannel itself, where endothelial cells are seeded to form an endothelial lining. One method, sacrificial molding, employs a structural placeholder removed before cell seeding to generate open lumina within a hydrogel. Alternatively, the microchannels themselves serve as the vessel structure and are circumferentially seeded with endothelial cells as a vessel replica. As a biomimetic approach, Costa et al. established an in vitro thrombosis model where the authors used angiography data from computed tomography data to create patient-derived 3D-printed vessel constructs of normal and stenotic vessels [139]. These biomimetic biochips were cellularized with HUVEC and perfused with human blood at physiologically shear rates, resulting in induced thrombosis only in pathological geometries. A more frequently used microchannel patterning approach casts a polymer onto molds representing a semi-circular vessel analog and subsequent bonding to another semi-circle to form a fully circular vessel. Some current examples of this method include circumferential alignment of endothelial cells and smooth muscle cells for a model of in vivo-like vasculature [140] or a model for investigation of the effect of topography and substrate rigidity on an endothelial cell layer [141]. Combined with increasingly sophisticated microfabrication techniques [142], microchannel patterning of PDMS on SU8 substrates could be a powerful tool for mimicking in vivo-like capillary structures in the future. As an alternative to PDMS, various hydrogels have been used to produce microchannels. For example, Nie et al. [143] and He et al. [144], recently demonstrated the use of various ECM-mimicking hydrogels and combinations for casting bifurcated networks that represent vessel anatomy.

A

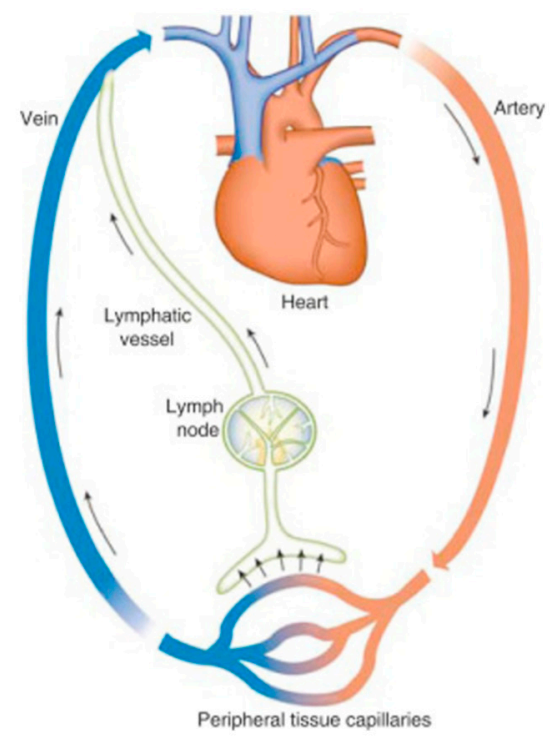

B

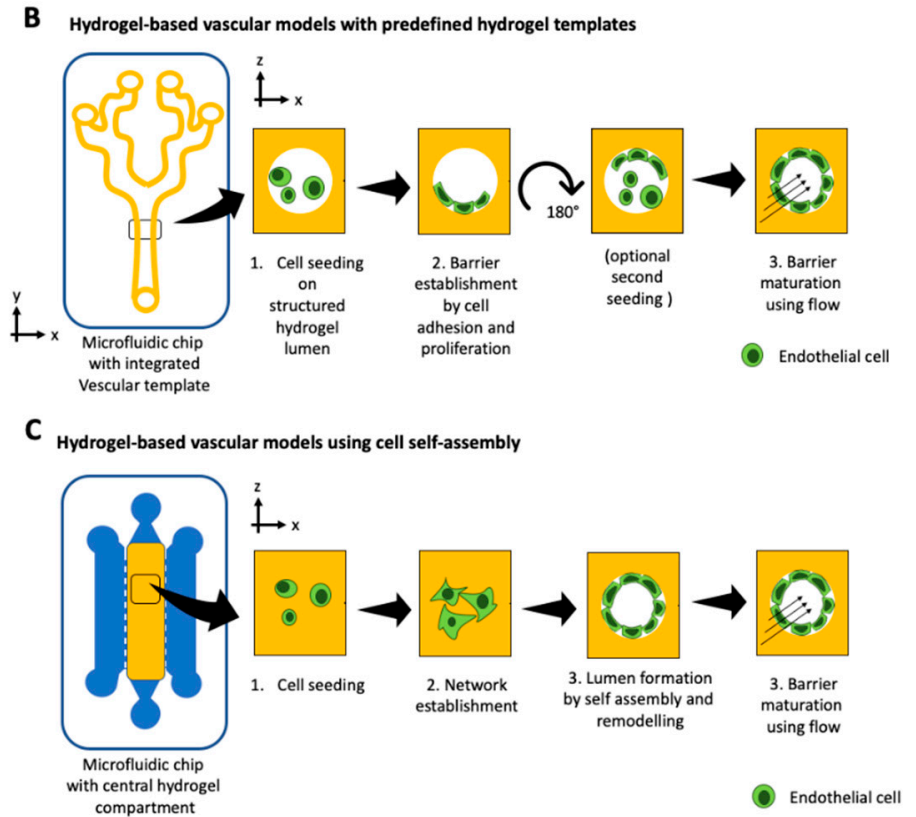

Figure 3. (A) Schematic of the circular and closed blood vascular and open-ended lymphatic system. (Reproduced from Reference [145] with permissions from Elsevier 2021.) Hydrogel-based organ-on-a-chip approaches for vasculature using (B) a predefined on-chip hydrogel template that is cellularized after printing or (C) cellular self-assembly and remodeling of a bulk hydrogel matrix where endothelial cells start to sprout, form a pre-vascular network, and mature over time into a lumenized vascular structure.

Furthermore, Menon et al. recently established a novel ECM patterning method for creating perfusable vascularized channels based on the capillary burst valve concept [146]. Using this novel method, the authors achieved various geometries and could mimic neutrophil trans-endothelial migration as well as stenosis in atherosclerosis. The implemen- 
tation of hydrogel molding techniques in microfluidic devices could go as far as recreating a vessel on chip with the ability of subsequent direct surgical anastomosis [147]. In contrast to hydrogel patterning, another microfluidic assisted approach-sacrificial molding-utilizes a needle-based technique where a hypodermic needle is inserted into a microfluidic structure before injection of a hydrogel [148]. The needle is subsequently removed upon hydrogel polymerization, thus, leaving a cylindrical void in the hydrogel for endothelial cell seeding. The seeded endothelial cells then form an endothelial cell barrier lining the inner walls of the channel, thus, creating a single perfusable vessel. The sacrificial molding method can be employed for: (i) single-cell systems containing only endothelial cells [149], (ii) multicellular systems including supporting cell types such as fibroblasts or stem cells [150], or even (iii) to recreate all three layers (adventitia, tunica media, and tunica negra) of a biomimetic blood vessel [151]. Further examples for successful implementation of the sacrificial molding method include studies to investigate vascular barrier transport [152]. For example, it has recently been employed by Christopher Chen's group to identify a previously unknown Notch-signaling pathway and elucidate the effect of inflammation on the vascular barrier [153]. Unfortunately, only one model employing sacrificial molding for lymphatic vessels has been reported so far [154]. However, in their model, Gong et al. report a microscale lymphatic vessel ( $\mu \mathrm{LYMPH})$ impressively exhibiting similar permeability and draining functions as in vivo lymphatics. Alternatively, lumenized microfluidic templates with better yield and performance can be created with viscous finger patterning, as demonstrated by Bischel et al. [155], where a lumen inside cell-laden hydrogels can be created prior to polymerization by hydrostatic flow of culture medium. The study of de Graaf et al. [156] investigated the robustness and reproducibility of this technique with different pumping regimes and identified that their extended passive pumping produced the lowest inter-lumen and intra-lumen variations less prone for user variations. The second option for recreating vascular structures in microfluidic devices is the self-assembly of vessels from single cells. Contrary to the microfluidic assisted methods mentioned above, where hollow structures resembling a vessel are generated before cell seeding, self-assembly utilizes vascular cells' inherent ability to form interconnected vascular structures through angio- and vasculogenesis. The method, pioneered by Roger Kamm's group, features endothelial cells and supportive cell types resuspended in a hydrogel and, subsequently, loaded into a microfluidic device [157]. Upon device loading, the cells initiate processes similar to vasculogenesis in vivo, resulting in a perfusable vascular network spanning between two medium channels. The endothelial cells and supportive cell types can either be embedded within the same hydrogel for direct cell-cell interaction or separated by a medium channel for vascular assembly via paracrine signaling. These self-assembled microfluidic in vitro vascular networks are an ideal tool for studying basic biologic processes, diseases, and even exposure to drugs or toxic compounds. For example, interstitial flow and growth factor gradients have long been assumed to play a vital role in vasculogenesis. Microfluidic devices can generate and maintain directional interstitial flow and growth factor gradients, demonstrating that both factors play a vital role in endothelial cell sprouting $[8,158,159]$. The only publication, to date, describing lymphatic endothelial cells in a self-assembly microfluidic setup showed that, while blood endothelial cells preferentially sprout in the direction of the interstitial flow, lymphatic endothelial cells favor angiogenesis toward the interstitial flow, successfully recreating a physiological response emulating the capillary bed [160]. Aside from basic biology, self-assembled vascular structures are routinely employed to study the delivery of drugs or even toxic compounds via the vascular system because on-chip vascular models exhibit similar permeability and transcellular and paracellular transport mechanisms as an in vivo vasculature [161]. As an example, Zeinali et al. investigated the effect of the anti-vasculogenic drug Nintedanib to understand the mechanisms underlying the course of action of routinely administered drugs for idiopathic pulmonary fibrosis [162]. The study found that the drug's effect was visible even at minimal concentrations, leading to a significant increase of vascular permeability, a decrease of vessel diameter and density, and fibroblast organization around 
the blood vessels. Finally, self-assembled microfluidic vasculature models have recently been employed to elucidate toxic nanoparticles' effect on blood vessels. Jeon et al., for instance, report that the oxidative stress upon exposure to cationic polymer nanoparticles leads to a rearrangement of microtubules and vessel contraction before caveolae-mediated transcytosis [163]. Additionally, atmospheric nanoparticles have been found to disturb multiple vascular-associated molecule expressions by forming a protein corona upon inhalation, leading to enhanced vascular permeability by losing tight junctions [164]. Overall, microfluidic models of vasculature have been routinely used to study physiologic and pathologic responses in vitro over the last five years and have proven to be a powerful tool not only for understanding the basic biology involved in vessel formation but also for the effects of drugs and toxic compounds on the human body's vascular systems. To provide a technology platform that offers better scalability and can be combined with robotic automation, Phan et al. established micro-vasculatures on a 96-well plate format [165] to independently perfuse microvascular organoids by hydrostatic pressure based on their 3D micro-tumor biochip design [166].

\section{Blood-Brain-Barrier-on-a-Chip: Barrier Function, Transport Properties, and Neuroinflammatory Model}

The blood-brain barrier (BBB) is a highly selective barrier, which ensures the separation of the circulating blood from the central nervous system (CNS). By strictly controlling the transport of molecules and ions, it is essential in maintaining cerebral homeostasis [167]. However, this complex selectivity also prevents potential therapeutics from reaching their cerebral target, rendering the BBB the biggest obstacle in cerebral drug delivery [168]. Therefore, many studies employing organ-on-chip technology have focused on unravelling the complexity of the BBB (see overview in Table 8). Over the years, four distinct chip designs within BBB-on-a-chip platforms have been developed, including the sandwich, the parallel, the tubular structure, and the vasculogenesis design (see Figure 4A-D). With an upper channel and a lower channel separated by a porous membrane, the sandwich design tries to recapitulate the traditional Transwell-type assembly. Usually, endothelial cells are seeded in the upper channel while astrocytes, pericytes, or other cells of the CNS are seeded in the bottom channel. Due to its configuration and the poor transparency of porous membranes, imaging capabilities are limited to advanced confocal imaging techniques. The emergence of transparent membrane materials such as PTFE have improved these limitations [169]. Falanga et al. employed transparent PET membranes for studying the effect of particle decoration with the membranotropic peptide gH625 and the iron-mimicking peptide CRTIGPSVC on the transport of nanoparticles across a murine BBB, based on b.End3 brain endothelial cells [170]. Brown et al. have adapted and improved the traditional sandwich design and generated a human neurovascular unit (NVU) model that allowed paracrine signaling of the co-cultured cells in a more physiological setup, by seeding brain microvascular endothelial cells on the bottom side of the membrane and introducing human pericytes, astrocytes, and neurons in a collagen hydrogel above [171]. In addition to an in vivo-like scaling, this study revealed a beneficial effect of pericyte conditioned medium on the integrity of the BBB at around $35 \mathrm{kOhms} / \mathrm{cm}^{2}$ and demonstrated the barrier protective properties of ascorbic acid, as well as the detrimental effects of glutamate. Recently, Maoz et al. have linked three sandwich chips to model the influx into the BBB, the brain parenchyma, and the efflux out of the BBB [172]. The linked NVU model was able to mimic metabolically critical physiological functions and cell phenotypes of the NVU, outperforming previous NVU in vitro models. Furthermore, the authors showed how methamphetamine exerted its effects on BBB influx rather than on the BBB efflux. Employing their human BBB-on-a-chip model based on iPSC-derived brain microvascular endothelial cells, Park et al. demonstrated the influence of hypoxia on the transport of chemicals and therapeutic antibodies (e.g., cetuximab) [173]. By exposing iPSCs to either normoxic or hypoxic conditions during differentiation into brain endothelial cells, it resulted in a more than five-fold increase in barrier tightness. In addition, selective transport of an anti-Transferrin receptor (TfR) antibody was demonstrated by perfusing an- 
tibodies at the vascular side of the hypoxia-differentiated BBB model. The more permeant MEM75 antibody was able to penetrate into the CNS channel, while retaining generally tight barrier properties. It is important to note that this clinically, highly relevant form of shuttling across the BBB could not be replicated in a standard Transwell set-up, due to its poor barrier function and high level of paracellular influx, underlining the importance of micro-physiological systems.

A

Sandwich design with apical and basolateral compartment separated by a porous membrane (Transwell type)
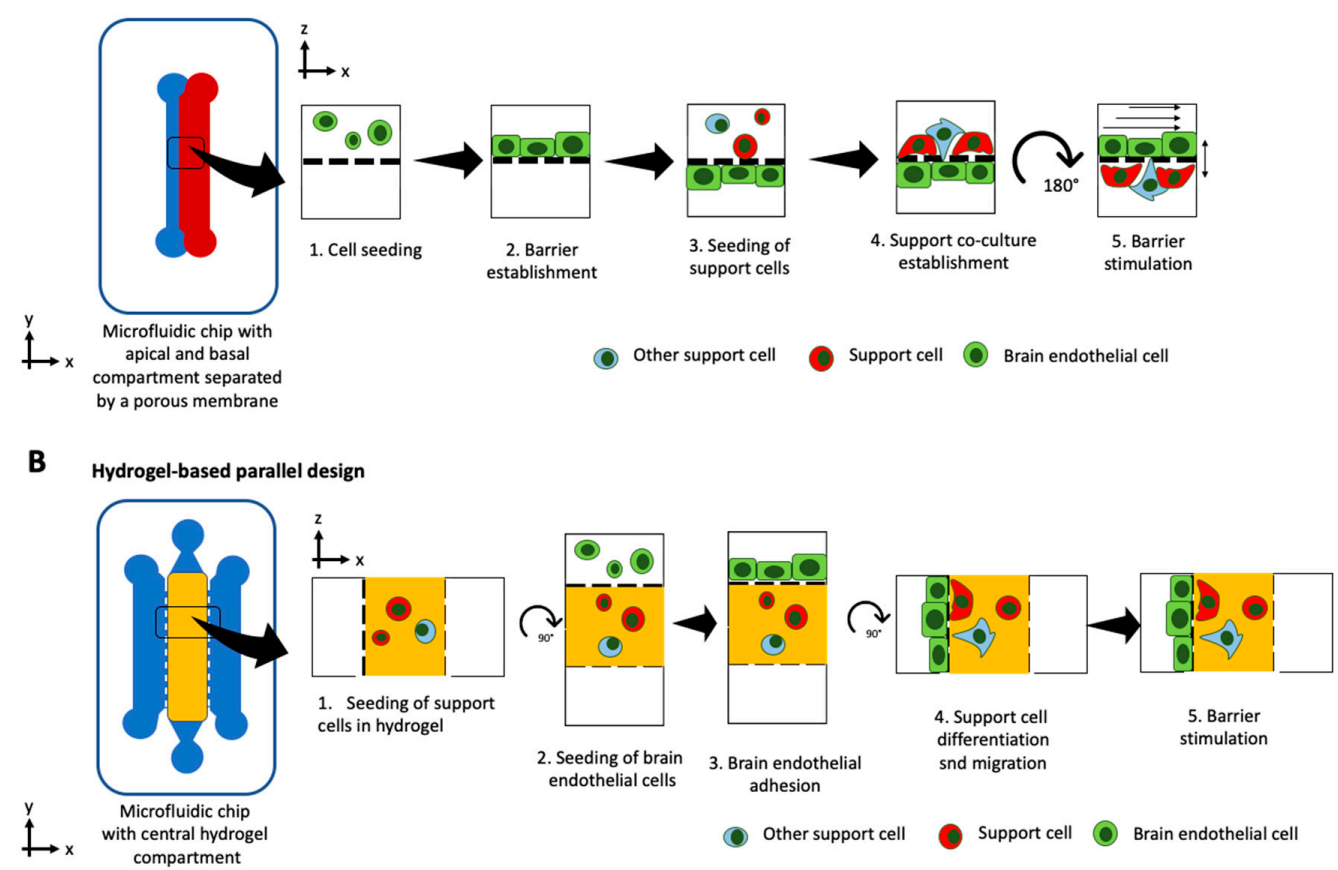

C Hydrogel or PDMS-based vascular models with predefined tubular hydrogel templates

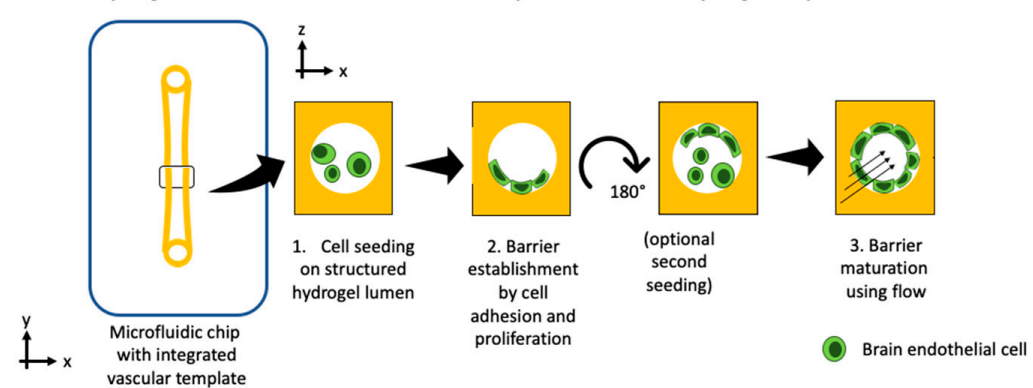

D Hydrogel-based vasculogenesis design

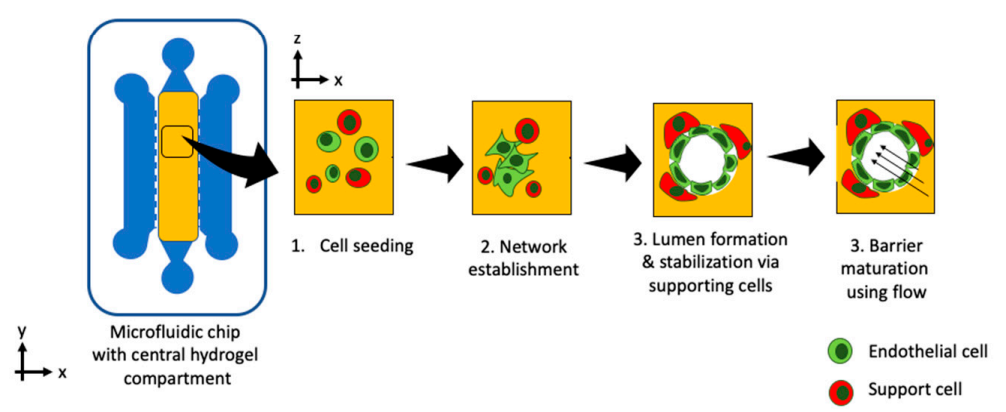

Figure 4. Basic principles for BBB-on-a-chip models using (A) tubular designs with a predefined tubular template, (B) hydrogel-based vasculogenesis design that promotes self-assembly of lumenized brain endothelial vessel structures with support cells, (C) sandwich Transwell design with co-cultures either on the bottom membrane side or bottom microchannel surface, or (D) parallel design similar to the vasculogenesis type, where the first support cells are embedded in the center hydrogel compartment and brain endothelial cells are consecutively seeded on one side of the hydrogel walls. 
Within the parallel design, microchannels are aligned in parallel, replacing the need for a porous membrane. The parallel design, thereby, improves the two main disadvantages associated with the sandwich design: limited cell-cell interactions and poor imaging capabilities. By using a $3 \mu \mathrm{m}$ gap micropillar array, Deosarker et al. were able to replace a porous track-etched membrane to separate neonatal rats' endothelial cells and astrocytes [174]. This platform enabled direct cell-to-cell interactions and revealed the importance of astrocytes as well as astrocyte-conditioned medium on barrier integrity. By introducing breast cancer cells in the outer chamber, Terrell-Hall et al. [175] were able to show that cancer cells disrupt BBB integrity while the efflux transporter $p$-glycoprotein function remains intact. Similar to Brown et al. for the sandwich type, Adriani et al. expanded the design concept of the parallel design by connecting four channels in parallel, accounting for neurons, astrocytes, and endothelial cells and their respective media [176]. This 3D neurovascular chip supported cell-specific characteristics and demonstrated that the brain microvascular endothelial cell line hCMEC/D3 outperformed the umbilical vein endothelial cell line HUVEC for BBB applications. By using the MIMETAS OrganoPlate ${ }^{\circledR}$, Wevers et al. [177] have enabled the study of antibody transcytosis in a human BBB model, that is capable of high throughput screening.

In contrast to the two rectangular design types mentioned above, the 3D tubular structure design provides cylindrical 3D microchannels and, thus, uniform shear stresses along the channel wall. By combining 3D printing with microneedles, Kim et al. were able to generate and cultivate mouse 3D brain microvessels based on b.End3 and mouse astrocytes for a period of three weeks, that recovered within four days after a D-mannitol-induced barrier disruption [178]. By coating a PDMS channel with collagen and seeding it with the immortalized rat brain endothelial cell line RBE4, Cho et al. developed a simple tubular BBB model for neuroinflammatory studies using TNF- $\alpha$ stimulation [179]. Unfortunately, ROS induction during oxygen-glucose-deprivation in an induced ischemia study did not show the expected regenerative capacity of Rho Kinase inhibition by Y-27632, and treatment with the antioxidant edaravone, which is a neuroprotectant used after acute ischemic stroke. Employing the fluidic technique of 'viscous finger patterning,' Herland et al. [180] generated a collagen hydrogel-based microchannel for the tubular co-culture of hBMVEC with human astrocytes or pericyte, respectively. Interestingly, throughout a three-day culture period, this tubular BBB model showed distinct differences in G-CSF and IL-6 secretion compared to Transwell cultures when challenged with TNF- $\alpha$. Another fabrication technique for 3D tubular devices is two-photon lithography. Using this technique, Marino et al. have been able to produce tubular structures with geometries similar to those of capillaries. Due to its high printing resolution, bioprinting via two-photon polymerization, thus, provides a promising technique to recreate brain vasculature with in vivo-like geometries. By leveraging celullar self-assembly and self-organization, the vasculogenesis strategy constitutes an alternative approach in BBB organ-on-a-chip technology that focuses on the de novo formation of microvessels in vitro. In their study, Bang et al. not only generated a 3D self-organized BBB vascular network [181] with synaptic astrocyte interaction, but, in the process, determined optimal co-culture medium formulations. Recently, Campisi et al. [182] have published a 3D vasculogenesis model that encompasses human iPSC-derived endothelial cells, human pericytes, and human astrocytes in a microvascular network, capable of emulating physiological vessel geometries (lateral diameter lower than $50 \mu \mathrm{m})$. Overall, these four approaches can recapitulate basic functions of neurovascular and blood brain barrier functions with the biological and physiological advances lagging behind the vast progress in technological development and platform establishment. In addition, brain chips should not be expected to model and recapitulate the complex heterogenous architectures found in the human brain any time soon as this organ comprises a variety of highly specialized and localized anatomies including (please see comprehensive reviews, such as Matorakos and McGaven, for architectural details [183]), i.e., (i) meningeal and cortical vascular structures, (ii) capillary and postcapillary venules within brain parenchyma, (iii) fenestrated vessels in the choroid plexus as well as (iv) fenestrated 
vasculatures at the center of circumventricular organs (CVOs), and (v) traditional BBB architectures spanning around the perimeter of CVOs.

\section{Central Nervous System-On-A-Chip: From Neurodevelopment to Drug Testing and Brain Disease}

The central nervous system (CNS) constitutes the control panel of the human body. Characterized by its high complexity and plasticity in health and disease, the CNS has long been the subject of intense research. Organ-on-a-chip technology has provided a powerful new toolkit for the study of the CNS due to its ability to, at least in part, reconstruct specific structural features of the CNS's highly complex architecture (see overview in Table 9). Among several areas of application, the recreation of neuronal networks using microfabricated platforms presents one of the largest. By introducing neurons and glial cells from multiple regions of the brain in a microfluidic chip and functionally connecting them, Dauth et al. have generated a novel, multiregional, neuronal network-on-chip, capable of demonstrating distinct properties of the hippocampus, the amygdala, and the prefrontal cortex [184]. The differences, which manifested themselves in aspects such as metabolism and electrophysiological activity changed upon functional connection, highlighting the importance of interconnectivity for studying physiological brain functions. Bang et al. were able to generate aligned neural circuits with visualizable synapses, thus, providing a microfluidic system with the potential applicability in CNS synapse research as well as neuro-muscular junction studies [185]. Similarly, Sances et al. recently employed microfluidics to study the effect of brain microvascular endothelial cells on the development of spinal motor neurons. Microfluidic vascular-neural co-cultivation led to enhanced neuronal function and in vivo-like signatures [186]. MacKerron et al. developed a microfluidic platform that can be used for the pharmacological profiling of CNS active compounds, based on an integrated calcium imaging readout [187]. Furthermore, the system might be of potential use in the study of neuromodulation and synaptic plasticity. Advances in both induced pluripotent stem cells (iPSCs) technology as well as organoid technology have enabled the generation of three-dimensional cellular constructs, capable of emulating both architectural and functional features of many organs, including that of the human brain in vitro [188]. While iPSC-derived organoids provide a powerful tool for modeling and understanding organ development, by recapitulating early developmental processes, differences still persist. These differences can mainly be ascribed to the lack or incorrect presentation of microenvironmental factors, such as biochemical and physical cues as well as multicellular interactions in a time-resolved and spatially-controlled manner. Combining organ-on-a-chip technology with iPSC technology, thus, provides a powerful strategic approach to address these limitations. By transferring embryoid bodies in a threedimensional matrix within a microfluidic device, Wang et al. were capable of differentiating human cerebral organoids over a period of 33 days in perfusion [189]. These cerebral organoids not only displayed well-defined neural differentiation, regionalization, and cortical organization but exhibited an enhanced expression of cortical layer markers when compared to their static counterpart. In a follow-up study, Wang et al. could demonstrate that prenatal nicotine exposure causes a disruption in brain regionalization, as well as cortical development, coupled with abnormal neuronal differentiation and migration [190].

In their developmental study, Karzbrun et al. harnessed the advantages of microfluidics to study the physics and biology of early human brain development by revealing the mechanisms of wrinkling in a living system [191]. By introducing embryoid bodies into a micropillar array, Zhu et al. could demonstrate the advantages of microfluidics for the high content generation of human brain organoids for industrial applications [192]. While these studies could already demonstrate the beneficial effects of using organ-on-a-chip technology for brain organoid development studies, as of today, only a few studies have combined iPSC-derived brain organoids with microfluidics.

Due to the growing awareness that compounds, such as pesticides, can have detrimental effects on the health of the CNS, microfluidic platforms have been increasingly employed for toxicological applications. Recently, Koo et al. published a 3D tetra-culture 
platform for organophosphate toxicity screening [193]. This in vitro model was able to demonstrate the ability of organophosphates to penetrate through the BBB, subsequently inhibiting acetylcholinesterase activity and eliciting toxic effects, similar to those overserved in vivo. By interconnecting neurospheres and liver spheroids in a multi-organ-on-a-chip platform, Materne et al. have provided a potential tool for long-term substance testing that takes inter-organ cross-talk into account [194]. Exposure to the neurotoxic compound 2,5-hexanedione resulted in an increased sensitivity toward the compound for both neurospheres and liver spheroids upon co-culturing for 14 days, highlighting the importance of multi-organ approaches for toxicological studies.

A major focus of current organ-on-a-chip approaches is put toward the study of diseases of the CNS. To investigate nerve-cancer interactions in vitro, Lei et al. developed a high-throughput chip for potential drug screening applications [195]. The study revealed that neurons provide biophysical support to and guide directional movement of cancer cells. It was shown that cancer types with high perineural invasion display better migration capabilities along neurons and that, by specifically addressing pathways involved in neuron-cancer signaling, cancer migration could be inhibited in vitro. Fan et al. developed a 3D high-throughput screening platform for the generation of glioblastoma multiforme spheroids and subsequent administration of drugs via an integrated gradient generator [196]. In a follow-up study, the chip was used to demonstrate the beneficial effect of a combinatorial treatment of glioblastoma multiforme spheroids with the two clinical drugs, avastin and temozolomide, compared to temozolomide treatment alone.

The prevalence of neurodegenerative diseases, such as Parkinson's disease and Alzheimer disease, and the concurrent lack of suitable treatment strategies have called for alternative disease models, capable of emulating disease onset and progression [197]. While the development of such CNS disease models progresses moderately, promising developments have been made. For instance, Park et al. developed a microfluidic array for the dynamic cultivation and subsequent exposure of 3D neurospheres to amyloid-beta, a peptide strongly associated with Alzheimer's disease [198]. Dynamic cultivation resulted in larger spheres and robust neuronal networks, that were once exposed to the neurotoxic peptide displayed reduced viabilities, neural destruction, and synaptic dysfunction, which are all pathophysiological features of Alzheimer's in vivo. Recently, Osaki et al. generated an amyotrophic lateral sclerosis model by combining three-dimensional skeletal muscle bundles with iPSC-derived motor neuron spheroids [199]. This system was not only able to demonstrate distinct differences between healthy and diseased motor neurons but, in addition, could prove that rapamycin and bosutinib cotreatment has considerable potential for ALS treatment.

\section{Multi-Organ on-Chip Models: Combined Tissue Models to Screen Drug-Drug Interactions, Pharmacokinetics, and Pharmacodynamics}

Drug-induced toxicities in liver, heart, kidney, and brain currently account for more than $70 \%$ of drug attrition and withdrawal from the market. Adverse drug reactions are often caused by off-target interactions or excessive binding of the drug to toxicity-prone cells [200]. Since inadequate pharmacokinetics (PK) and pharmacodynamics (PD) are key factors in drugs failure, interconnected multi-tissue cell culture models are considered to be a useful tool to investigate the pharmacokinetic profiles of drug molecules. For instance, drug-to-drug interactions were investigated by a combination of a mathematical PK-PD model and the experimental results using the multi-organ-on-a-chip (MOoC) as reported by Shinha [201]. In detail, the effects of metabolites of the anti-cancer pro-drug CPT-11 on lung cancer cells were determined. To evaluate DDI and resulting changes in drug concentration and metabolic capacity, the inhibitory capacity of simvastatin and ritonavir on the metabolism of CPT-11 was tested. The presented MOoC consisted of a pro-drug metabolizing liver part (HepG2 cells), a lung cancer part (A549 cells), and a stirrer-based micropump connected by micro-channels. Drug-specific parameters were determined by a combination of a simulated PK-PD model and the experimental results, showing comparable results and, ultimately, suggested that the combination of the PK-PD model 
and the MOoC is a useful way to predict adverse effects of drugs. In a more advanced, pneumatic, pressure-driven, four-organ system composed of intestine, liver, cancer, and connective tissue models, the effects of the anti-cancer drug 5-FU and the two pro-drugs of 5FU (CAP and tegafur) were evaluated in terms of intestinal absorption, hepatic metabolism, and growth inhibition in cancer and connective tissue [202]. Additionally, Maschmeyer et al. integrated skin biopsies in a four-organ device consisting of liver, intestine, skin, and kidney model to recapitulate in vivo absorption, distribution, metabolism, and excretion behaviours [203].

Since cardiac and liver toxicity are the leading causes of post-approval drug withdrawals, these tissue types are of great interest to assess multi-organ drug interactions [204]. For instance, Oleaga et al. presented a multi-organ-on-a-chip platform, which allowed the analysis of a long-term cardiomyocyte and hepatocyte co-culture [205]. Using a MEA and a cantilever array, electrical activity and mechanical function of the cardiac cells could be determined and cardiotoxic effects of two drugs due to hepatic metabolism was observed. Similarly, a dual-organ-on-a-chip system was presented by Zhang et al. for automated analysis of an in vitro heart and liver organ model [206]. Biomarker (as albumin, glutathione S-transferase $\alpha$, and creatine kinase MB) secretion was measured by functional electrodes, while environmental conditions (e.g., oxygen levels, temperature profiles) were observed. The drug testing capabilities and efficiency of the system were demonstrated by using acetaminophen and doxorubicin [207]. Moreover, Maoz et al. used a combination of TEER and MEA to enhance the analysis outcome of a myocardial barrier model [208]. Dynamic changes in this heart model, consisting of cardiomyocytes and a primary human endothelial cell monolayer, could be detected after challenging it with TNF- $\alpha$ as well as isoproterenol, which is a cardiac targeting pro-drug. The latest heart-on-a-chip developments involve emulating more complex, biological tissue-tissue interactions on a chip. Skardal et al. advanced the heart and liver organ-on-a-chip system by implementing a lung model in the same system [209]. The individual organ models were bio-printed and consisted of primary human hepatocytes, stellate cells, and Kupffer cells for liver organoids, induced pluripotent stem cells for heart organoids, and lung fibroblasts, epithelial cells, and endothelial cells for lung membranes. Analysis of the system was performed by measuring cardiac beating rates by real-time imaging, antibody-binding by impedance spectroscopy, and barrier function by TEER (as an addition to traditional supernatant analysis). When investigating potentially toxic effects of bleomycin on the lung organ model, adverse effects on the cardiac organoid was observed, which did not occur when treating the cardiac model alone with the same compound. This indicates the importance of multi-organ models to reveal interactions between multiple tissues and organs. Novak et al. demonstrated how an automated solution can investigate complex, vascularized, multi-organ systems with the group's robotic interrogator and shows the potential of robotic solutions to solve the scalability of medium exchange as well as sampling of multi-organ systems [210]. As an application example, the system was used for long-term pharmacokinetic analysis of inulin-FITC for up to three weeks in an eight-organ system linked via vasculature and supported by computational PBPK modelling.

\section{Conclusions}

Organs-on-a-chip systems underwent a decade-long transformation and constant improvements to better emulate physiological or pathophysiological conditions, which already led to a deeper understanding of human physiology and disease progression at the micro-scale. While the majority of the organs-on-a-chip systems are used in academic settings, a small number of systems have shown real-world applications in the pharmaceutical industry, including CNS, vascular, heart, skin, liver, kidney, lung, and BBB models (see Tables 1-5 and 7-9). The selected organ models have shown improved outcomes over existing Transwell cultures and used relevant bioactive molecules to demonstrate potential pharmaceutical applications. It is important to note that recent organ-on-a-chip progress has primarily been achieved by interdisciplinary approaches combining iPSC technology, 
cell self-assembly, microfabrication, and bioprinting to support cell-based microfluidics. Given the biological complexity of the described organ-on-a-chip system, future progress will likely be made in sensor integration to monitor key physiological parameters [18]. Overall, the current status of the described organs-on-a-chip system are summarized below.

Lung-on-a-chip: Among the first organs-on-a-chip to be developed, the basic chip designs did not change over the last decade besides some minor improvements in the stretching actuation and integrated sensing modules. Recent improvements relate to the integration of primary lung cell lines in combination with other cell types, such as endothelial cells, to mimic human pathologies and treatment. The apparent lack in technological progress can be associated with the excellent performance of the biochips capable of recapitulating important aspects and pathways of human lung pathologies, such as asthma, COPD, or lung cancer that are needed for drug screening.

Skin-on-a-chip: When looking into the progress of skin-on-a-chip systems, improvements are evident in the increased architectural features, such as inclusion of fat or nerve tissue as lipophilic drug reservoir, immune cells, and the nervous system. The application of skin-on-a-chip systems for pharmacological application lies mainly in the interconnection with other human tissues, where the skin compartment plays a role in transdermal transport, accumulation, and release of drugs and pro-drugs into a multi-organ-on-a-chip system comprising of hepatic metabolism, vasculature, and selected target tissues, such as kidney and heart.

Liver-on-a-chip: liver-on-a-chip systems have been shown to successfully mimic the enzymatic activity, spatial-organization, and anatomical along with ultra-structural features of the human liver. Consequently, future applications will involve the establishment of personalized disease models including relevant liver cell sources as primary hepatocytes and non-parenchymal cells to control structural, mechanical, and biochemical cues for investigating fundamental aspects of, e.g., non-alcoholic liver diseases (steatosis, cirrhosis, liver, and fibrosis) or alcoholic liver disease. For the production of next-generation multiorgan-chips, the establishment of liver-on-chip compartments is crucial since they play a leading role in the interconnection to other organs in terms of pharmacokinetics, drug metabolism, disease progression, and drug-induced hepatotoxicity.

Kidney-on-a-chip: chip-based kidney systems are still in its infancy due to technical and biological constraints on the recreation of the proper anatomical architecture of a single functional nephron comprising of tubules, glomeruli, arterioles, and venules. During the past years, however, progress is made to recapitulate the structural, mechanical, transport, absorptive, and physiological properties of the human kidney using an on-chip monoculture (e.g., human podocytes) or co-culture models [211]. The bio-fabrication of functional kidney-on-chip systems for predicting drug efficacy and drug-induced kidney injury are, therefore, promising solutions for the detection of drug interactions and nephrotoxic effects in the near future.

Heart-on-a-chip: Similarly, heart models face the dilemma of being anatomically too inaccurate, considering the variety of functional structures of the human heart. However, their potential lies definitely in the creation of beating structures for drug screening and off-target cardiotoxicity studies, where the heart-on-a-chip system in combination with other tissues, such as liver and lung, shows promising progress.

Vascularization-on-a-chip: Vasculature-on-chip systems have demonstrated their applicability in multiple biological questions within the last decade. Existing techniques achieve meaningful vessel diameters and anatomies from arteries down to the capillary bed. However, the biggest challenge when using this vasculature as a conduit between organs in MOC still needs to be addressed. The integration of vasculature in place of microfluidic channels to connect organs would yield meaningful information on vessel health during drug exposure.

BBB-on-a-chip: While significant progress has been made in the development of highly complex BBB models, such as (i) the emulation of physiological shear forces, (ii) the integration of the cellular building blocks including astrocytes, endothelial cells, and 
pericytes, and (iii) the recapitulation of capillary morphologies in a self-assembled network, next generation BBB models will need to account for the drug target itself to further increase their applicability for pharmacological applications.

CNS-on-a-chip: Despite substantial advances in the modelling of the CNS employing microfluidic principles, efforts only recently ventured out to the recapitulation and interconnection of multiple regions of the brain as well as the integration of complex 3D tissues, such as brain organoids. With their ability to differentiate and reorganize into structural and functional analogues of the brain and its individual elements, next-generation CNSon-a-chip models employing brain organoid technology will provide a powerful tool for neurodevelopmental, pathological, and pharmacological studies. 
Table 1. Skin-on-a-chip applications.

\begin{tabular}{|c|c|c|c|c|c|c|c|}
\hline \multicolumn{4}{|c|}{ Device Specifications } & \multirow{2}{*}{$\begin{array}{l}\text { Assays } \\
\text { Assays }\end{array}$} & \multicolumn{3}{|c|}{ Additional Information } \\
\hline Device Material & 2D/3D & Application & Cell Type(s) & & Special Feature & Outcome & Ref. \\
\hline $\begin{array}{l}\text { PDMS and PET } \\
\text { porous membranes }\end{array}$ & Monolayer & $\begin{array}{l}\text { Skin epidermis, } \\
\text { inflamatory, edem }\end{array}$ & $\begin{array}{l}\text { Human keratinocytes HaCaT, } \\
\text { fibroblasts, Human umbilical vein } \\
\text { endothelial cells (HUVECs) }\end{array}$ & $\begin{array}{l}\text { Response to TNF-a (mRNA } \\
\text { expression levels ELISA), Tight } \\
\text { junction staining, leakage assay }\end{array}$ & $\begin{array}{l}\text { Multi barrier competent } \\
\text { Chip (3) }\end{array}$ & $\begin{array}{c}\text { TNF- } \alpha \text {-induced } \\
\text { inflammation treatment } \\
\text { with drug DEX }\end{array}$ & [74] \\
\hline $\begin{array}{l}\text { Polycarbonate } \\
\text { cover-plates, } \\
\text { PDMS-glass chip }\end{array}$ & Biopsy & $\begin{array}{l}\text { Oral and ermal } \\
\text { ubstance absorption }\end{array}$ & Prepuce samples & $\begin{array}{l}\text { Stratified stratum corneum at } \\
\text { the air-liquid interface, mRNA }\end{array}$ & $\begin{array}{l}\text { 4-organ-models for } \\
28 \text { days }\end{array}$ & $\begin{array}{l}\text { Absorption, } \\
\text { distribution, } \\
\text { metabolism, } \\
\text { and excretion }\end{array}$ & [203] \\
\hline $\begin{array}{l}\text { PDMS and PC } \\
\text { membrane }\end{array}$ & $3 \mathrm{D}$ & Air-Skin-Interface & Fibroblasts and keratinocytes & $\begin{array}{l}\text { Transdermal transport of } \\
\text { FAM-tagged oligonucleotides }\end{array}$ & Air-Skin-Interfaces & $\begin{array}{l}\text { Anti-proliferative role } \\
\text { of doxorubicin }\end{array}$ & [73] \\
\hline PDMS, membrane & $3 \mathrm{D}$ & Differentiation & Fibroblasts and keratinocytes & $\begin{array}{l}\mathrm{H \& E} \text {, Masson trichrome (MT), } \\
\text { and Sirius red staining }\end{array}$ & Gravity flow & $\begin{array}{l}\text { Skin differentiation } \\
\text { on chip }\end{array}$ & [72] \\
\hline $\begin{array}{l}\text { PC, PMMA, PTFE } \\
\text { filter membranes }\end{array}$ & $3 \mathrm{D}$ & Skin permeation & $\begin{array}{l}\text { N/TERT-1 keratinocyte, human } \\
\text { primary foreskin-derived dermal } \\
\text { fibroblasts }\end{array}$ & $\begin{array}{l}\text { Diffusion of caffeine, } \\
\text { testosterone, salicylic acid }\end{array}$ & $\begin{array}{l}\text { Micro device vs. Franz } \\
\text { diffusion cells }\end{array}$ & $\begin{array}{l}\text { As good as Franz } \\
\text { diffusion cells }\end{array}$ & [71] \\
\hline $\begin{array}{l}\text { PDMS, PMMA, PS, } \\
\text { PET membrane }\end{array}$ & $2 \mathrm{D}$ & Immune-competent & $\begin{array}{l}\text { Human keratinocytes (HaCaT) } \\
\text { human leukemic monocyte } \\
\text { lymphoma cell line (U937) }\end{array}$ & $\begin{array}{l}\text { TEER, lipopolysaccharides } \\
\text { impact, UV, nickle sulfate, cobalt } \\
\text { sulfate, glycerol, DNCB }\end{array}$ & $\begin{array}{l}\text { Immune response, } \\
\text { TEER on chip }\end{array}$ & ALI not possible & [75] \\
\hline Commercial Biochip & $2 \mathrm{D} / 3 \mathrm{D}$ & Air-Skin-Interface & $\begin{array}{l}\text { Murine fibroblasts (L929) and } \\
\text { EpiDerm }^{\mathrm{TM}} \text { RhE. }\end{array}$ & $\begin{array}{l}\text { TEER, impact of sodium } \\
\text { dodecyl sulphate }\end{array}$ & $\begin{array}{l}\text { Air-Skin-Interface, } \\
\text { TEER on chip }\end{array}$ & $\begin{array}{l}\text { Detection of tissue } \\
\text { break down }\end{array}$ & [67] \\
\hline PMMA & $\begin{array}{l}\text { 3D in fibrin } \\
\text { dermal matrix }\end{array}$ & $\begin{array}{l}\text { epidermal } \\
\text { morphogenesis }\end{array}$ & $\begin{array}{c}\text { Human primary foreskin-derived } \\
\text { dermal fibroblasts }\end{array}$ & TEER, Raman, 2PP microscopy & $\begin{array}{l}\text { orthokeratinized } \\
\text { full-thickness SE within } \\
\text { a microfluidic platform }\end{array}$ & $\begin{array}{l}\text { Industrial close } \\
\text { working chip design }\end{array}$ & [68] \\
\hline
\end{tabular}


Table 2. Lung-on-a-chip applications.

\begin{tabular}{|c|c|c|c|c|c|c|c|}
\hline \multicolumn{4}{|c|}{ Device Specifics } & \multicolumn{2}{|c|}{ Assays } & \multicolumn{2}{|c|}{ Additional Information } \\
\hline Device Material & 2D/3D & Application & Cell Type(s) & Special Feature & Sensing Principle/Assay & Outcome & Ref. \\
\hline PDMS & Monolayer, co-culture & $\begin{array}{l}\text { Alveolar-capillary } \\
\text { interface }\end{array}$ & $\begin{array}{l}\text { human alveolar epithelial cells and } \\
\text { microvascular endothelial cells }\end{array}$ & Stretchable membrane & $\begin{array}{c}\text { TEER, albumin transport, } \\
\text { neutrophil activation } \\
\text { through e. coli, } \\
\text { ROS, nanoparticle }\end{array}$ & $\begin{array}{l}\text { First biomimetic device } \\
\text { for breathing lung }\end{array}$ & [28] \\
\hline PDMS & Monolayer & Pulmonary edema & $\begin{array}{l}\text { Human pulmonary microvascular } \\
\text { endothelial cells (Lonza), Alveolar } \\
\text { epithelial cells NCI-H441 }\end{array}$ & Stretchable membrane & $\begin{array}{l}\text { interleukin-2 (IL-2) (for } \\
\text { leakage of ALI = edema) vs. } \\
\text { angiopoietin-1 and } \\
\text { drug GSK219387 }\end{array}$ & $\begin{array}{l}\text { GSK219387 closes } \\
\text { leakage from edema }\end{array}$ & [51] \\
\hline PDMS, PE Membrane & Monolayer, co-culture & Disease COPD & $\begin{array}{l}\text { Primary hAECs, human lung } \\
\text { microvascular endothelial cells }\end{array}$ & ALI & $\begin{array}{l}\text { interleukin-13 (IL-13) } \\
\text { reconstituted the goblet cell } \\
\text { hyperplasia, cytokine } \\
\text { hypersecretion, and } \\
\text { decreased ciliary function } \\
\text { of asthmatics }\end{array}$ & $\begin{array}{l}\text { Cytokines IL-8, M-CSF, } \\
\text { IP-10, and RANTES } \\
\text { healthy vs. COPD }\end{array}$ & [53] \\
\hline PDMS, PET membrane & Monolayer, co-culture & Impact of smoking & $\begin{array}{l}\text { Primary human small airway epithelial } \\
\text { cell, microvascular endothelium }\end{array}$ & $\begin{array}{l}\text { Cigarette smoke as ALI. } \\
\text { Also e-cigarette. }\end{array}$ & $\begin{array}{l}\text { upregulation of anti-oxidant } \\
\text { heme oxygenase } 1 \text { (HMOX1) } \\
\text { gene expression with smoke } \\
\text { exposure phosphorylation } \\
\text { of the antioxidant regulator } \\
\text { Nrf2 ciliary beat frequency } \\
\text { interleukin } 8 \text { (IL-8) secretion } \\
\text { of COPD cells influenced } \\
\text { by smoke }\end{array}$ & $\begin{array}{l}\text { Smoking upregulates } \\
\text { expression of } \\
\text { oxidation-reduction }\end{array}$ & [45] \\
\hline $\begin{array}{l}\text { PDMS, PET Membrane, } \\
\text { gold electrodes on PC }\end{array}$ & monolayer & $\begin{array}{l}\text { TEER and barriers (also } \\
\text { gut with } \mathrm{CaCo}^{2} \text { ) }\end{array}$ & $\begin{array}{l}\text { primary human airway epithelial } \\
\text { cells (hAECs) }\end{array}$ & TEER of ALI & $\begin{array}{l}\text { Application of chelating } \\
\text { agent EGTA }\end{array}$ & $\begin{array}{l}\text { EGTA leads to } \\
\text { destruction of barrier }\end{array}$ & [60] \\
\hline PDMS & 3D organoids & Organ toxicity & $\begin{array}{c}\text { Hepatic stellate cells (HSCs) }(+) \text {, primary } \\
\text { human hepatocytes }(+), \text { Kupffer cells }(+), \\
\text { induced pluripotent stem cell-derived } \\
\text { cardiomyocytes (iPSC CMs) }(*), \text { human } \\
\text { primary cardiac fibroblasts }(+), \\
\text { lung microvasculature } \\
\text { endothelial cells }(+), \text { airway stromal } \\
\text { mesenchymal cells }(+), \text { bronchial } \\
\text { epithelial cells }(+)\end{array}$ & $\begin{array}{l}\text { Cardiac beat rate } \\
\text { measurement by } \\
\text { real-time imaging and } \\
\text { computational analysis, } \\
\text { antibody-binding } \\
\text { by impedance } \\
\text { measurement, and } \\
\text { barrier function by } \\
\text { TEER measurement }\end{array}$ & $\begin{array}{l}\text { acetaminophen, } \\
\text { N-acetyl-L-cysteine on liver, } \\
\text { epinephrine and } \\
\text { propranolol on } \\
\text { heart, Bleomycin }\end{array}$ & $\begin{array}{l}\text { Interlinked responds of } \\
\text { combined organoids }\end{array}$ & [209] \\
\hline $\begin{array}{l}\text { PDMS, PDMS } \\
\text { membrane }\end{array}$ & $\begin{array}{l}\text { Lung monolayer, } \\
\text { whole blood } \\
\text { HUVECS channel wall }\end{array}$ & $\begin{array}{l}\text { Blood-air interface } \\
\text { pulmonary thrombosis }\end{array}$ & $\begin{array}{l}\text { HUVECs, human lung microvascular } \\
\text { endothelial cells (HMVEC-L), blood }\end{array}$ & $\begin{array}{l}\text { Blood for perfusion } \\
\text { of vessel }\end{array}$ & $\begin{array}{l}\text { Inflammatory } \\
\text { cytokine-induced } \\
\text { pulmonary thrombosis }\end{array}$ & $\begin{array}{l}\text { LPS endotoxin } \\
\text { indirectly stimulates } \\
\text { intravascular } \\
\text { thrombosis }\end{array}$ & [62] \\
\hline
\end{tabular}


Table 2. Cont

\begin{tabular}{|c|c|c|c|c|c|c|c|}
\hline \multirow[b]{2}{*}{ Device Material } & \multicolumn{2}{|r|}{ Device Specifics } & \multirow[b]{2}{*}{ Cell Type(s) } & \multicolumn{2}{|c|}{ Assays } & \multicolumn{2}{|c|}{ Additional Information } \\
\hline & 2D/3D & Application & & Special Feature & Sensing Principle/Assay & Outcome & Ref. \\
\hline $\begin{array}{l}\text { PDMS, PDMS } \\
\text { membrane }\end{array}$ & Monolayer & Blood-air interface & $\begin{array}{l}\text { Bronchial epithelial } 16 \text { HBE14o-cells, } \\
\text { Primary human pulmonary alveolar } \\
\text { epithelial cells (pHPAEC) }\end{array}$ & $\begin{array}{l}\text { Mechanical strain of } \\
\text { alveolar barrier } \\
\text { during breathing }\end{array}$ & IL-8 concentration, viability & $\begin{array}{l}\text { Stretching influencing } \\
\text { the transport of } \\
\text { small molecules }\end{array}$ & [56] \\
\hline $\begin{array}{l}\text { PDMS, flexible } \\
\text { circuit board }\end{array}$ & Monolayer & Blood-air interface & $\begin{array}{l}\text { Human type II alveolar epithelial-like } \\
\text { A549 cells (-) }\end{array}$ & $\begin{array}{l}\text { Mechanical strain of } \\
\text { alveolar barrier } \\
\text { during breathing }\end{array}$ & $\begin{array}{l}\text { Barrier movement and } \\
\text { membrane permeabilization } \\
\text { sensing by real-time } \\
\text { measurement of resistivity } \\
\text { changes in three } \\
\text { impedimetric coplanar } \\
\text { electrodes }\end{array}$ & $\begin{array}{l}\text { Monitoring in real-time } \\
\text { the integrity of an } \\
\text { epithelial barrier } \\
\text { located at a distance } \\
\text { of } 1 \mathrm{~mm}\end{array}$ & [57] \\
\hline PMMA & Monolayer & $\begin{array}{l}\text { Epithelial smooth } \\
\text { muscle interface }\end{array}$ & $\begin{array}{l}\text { Human airway epithelial cells (Calu-3), } \\
\text { human bronchial smooth muscle } \\
\text { cells (hBSMCs) }\end{array}$ & ALI & $\begin{array}{l}\text { Device characterization, } \\
\text { tight junctions }\end{array}$ & $\begin{array}{l}\text { Stable hydrogel-based } \\
\text { ALI }\end{array}$ & [65] \\
\hline PDMS & Spheroids & $\begin{array}{l}\text { photodynamic } \\
\text { therapy (PDT) }\end{array}$ & A549 and non-malignant MRC-5 & $\begin{array}{l}\text { 3D spheroids, } 384 \\
\text { wellplate based }\end{array}$ & $\begin{array}{l}\text { Verification of spheroid } \\
\text { viability, ALA accumulation, } \\
\text { ROS generation }\end{array}$ & $\begin{array}{l}\text { High PDT effectiveness } \\
\text { on lung spheroids } \\
\text { required additional } \\
\text { time after treatment. }\end{array}$ & [66] \\
\hline PDMS, silicon & Monolayer & $\begin{array}{l}\text { Lung } \\
\text { inflammation }\end{array}$ & $\begin{array}{c}\text { Beas-2B (ATCCsnumber: CRL-9609t) is a } \\
\text { human bronchialepithelial cell line } \\
\text { infected with an adenovirus (12-SV40 } \\
\text { hybridvirus, Ad12SV40 } \\
\text { peripheral blood } \\
\text { mononuclearcells (PBMCs) }\end{array}$ & Fibrocyte migration & Cell migration, ELISA & $\begin{array}{l}\text { CP, CXCL12, and } \\
\text { CXCR4 responsible for } \\
\text { fibrocyte extravasation } \\
\text { in lung inflammation }\end{array}$ & [63] \\
\hline $\begin{array}{l}\text { PDMS, PLGA for } \\
\text { membrane }\end{array}$ & Monolayer & Tumor invasion & A549, HFL1, and HUVECs & $\begin{array}{l}\text { Electro spinning of } \\
\text { PLGA membrane }\end{array}$ & $\begin{array}{l}\text { Device characterization, } \\
\text { f-actin, DAPI, Calcein-AM, } \\
\text { CD31 expression of } \\
\text { HUVECs }\end{array}$ & $\begin{array}{l}\text { Simulate in vitro the } \\
\text { tumor } \\
\text { microenvironment } \\
\text { alveolar } \\
\text { biochemical factors }\end{array}$ & [64] \\
\hline $\begin{array}{l}\text { PDMS, glass, } \\
\text { PET membrane }\end{array}$ & Monolayer & Lung & A549 & TEER (Evom) & $\begin{array}{l}\text { Surface tension influenced } \\
\text { by surfactant secretion }\end{array}$ & Chip higher TEER & [58] \\
\hline $\begin{array}{l}\text { Paraffin, glass, PET, and } \\
\text { PC membrane }\end{array}$ & Monolayer & Lung & Calu-3 & TEER (Evom) & 14C-sucrose permeability & $\begin{array}{l}\text { Permeability higher } \\
\text { through }\end{array}$ & [59] \\
\hline PDMS, glass & Monolayer & Lung & A549 & $\begin{array}{l}\text { Phosphor lipids, } \\
\text { lamellar bodies, F-actin }\end{array}$ & Formation of laminar bodies & $\begin{array}{l}\text { Laminar body } \\
\text { formation depends } \\
\text { on shear }\end{array}$ & [61] \\
\hline
\end{tabular}


Table 3. Liver-on-a-chip applications.

\begin{tabular}{|c|c|c|c|c|c|c|c|c|}
\hline \multicolumn{5}{|c|}{ Device Specifics } & \multicolumn{2}{|c|}{ Assays } & \multicolumn{2}{|l|}{ Additional Information } \\
\hline Device Material & 2D/3D & Culture Conditions & Cell Type(s) & Application & Staining & Assays & Outcome & Ref. \\
\hline $\begin{array}{l}\text { Polysterene } \\
\text { (Nortis) }\end{array}$ & $2 \mathrm{D}$ & Flow conditions, Collagen I & $\begin{array}{c}\text { Primary rat and } \\
\text { human hepatocytes }\end{array}$ & Hepatotoxicity & $\begin{array}{l}\text { Calcein-AM, } \\
\text { Ethidium- } \\
\text { homodimer1, } \\
\text { HNF4 } \alpha\end{array}$ & $\begin{array}{l}\text { Lactate dehydrogenase } \\
\text { (LDH) release, alanine } \\
\text { aminotransferase } \\
\text { (ALT), albumin } \\
\text { CYP1A1/2, and } \\
\text { CYP3A4 activities, } \\
\text { visualization o } \\
\text { canalicular structures }\end{array}$ & $\begin{array}{l}\text { Exhibited higher viability and } \\
\text { improved hepatic functions }\end{array}$ & [96] \\
\hline PDMS & $\begin{array}{l}\text { Bio-printed 3D } \\
\text { spheroids }\end{array}$ & $\begin{array}{l}\text { Spheroid culture } \\
\text { encapsulated within } \\
\text { photocrosslinkable } \\
\text { Gelatin methacryloyl } \\
\text { (GelMA) hydrogel }\end{array}$ & $\begin{array}{l}\text { human } \\
\text { HepG2/C3Aspheroids }\end{array}$ & $\begin{array}{l}\text { Drug toxicity } \\
\text { assessment }\end{array}$ & $\begin{array}{l}\text { cytokeratin } 18, \\
\text { MRP2 bile } \\
\text { canalicular protein, } \\
\text { and tight junction } \\
\text { protein } \mathrm{ZO}-1\end{array}$ & $\begin{array}{l}\text { Albumin, alpha-1 } \\
\text { antitrypsin, transferrin, } \\
\text { and ceruloplasmin }\end{array}$ & $\begin{array}{c}\text { Treatment with acetaminophen } \\
\text { induced a toxic response in the } \\
\text { hepatic construct that was } \\
\text { similar to published studies } \\
\text { on animals }\end{array}$ & [213] \\
\hline PDMS & 3D liver spheroids & $\begin{array}{l}\text { Flow conditions, } \\
\text { low-attachment } \\
\text { spheroid microplates }\end{array}$ & $\begin{array}{l}\text { HepaRG cells, 3D } \\
\text { pancreatic islet } \\
\text { microtissues }\end{array}$ & $\begin{array}{l}\text { Pancreatic islet-liver } \\
\text { crosstalk based on } \\
\text { insulin and } \\
\text { glucose regulation }\end{array}$ & $\begin{array}{l}\text { Insulin, glucacon, } \\
\text { cytokeratin } 8 / 18, \\
\text { vimentin, albumin, } \\
\text { CYP3A4 }\end{array}$ & $\begin{array}{l}\text { Albumin, glucose, } \\
\text { insulin }\end{array}$ & $\begin{array}{l}\text { Demonstrated a functional } \\
\text { feedback loop between the } \\
\text { liver and the insulin-secreting } \\
\text { islet micro-tissues }\end{array}$ & [214] \\
\hline $\begin{array}{l}\text { 3D Perfusion } \\
\text { IbiTreat, (Ibidi) }\end{array}$ & $2 \mathrm{D}$ and 3D & $\begin{array}{c}\text { hyaluronan and } \\
\text { poly(ethylene glycol) } \\
\text { (HA-PEG), alginate and } \\
\text { agarose hydrogels for 3D, } \\
\text { PLL or HEP Coat coated } \\
\text { for 2D }\end{array}$ & $\begin{array}{l}\text { HepG2 and } \\
\text { hiPS-HEP }\end{array}$ & $\begin{array}{c}\text { Comparison of } \\
\text { agarose, alginate, } \\
\text { and } \\
\text { HA-PEG hydrogels }\end{array}$ & - & $\begin{array}{l}\text { Rheology, dextran } \\
\text { diffusion }\end{array}$ & $\begin{array}{c}\text { In HA-PEG hydrogels, } \\
\text { 3D hiPS-HEPs showed an } \\
\text { increased viability and higher } \\
\text { albumin production compared } \\
\text { to cultures in the } \\
\text { other hydrogels }\end{array}$ & [95] \\
\hline $\begin{array}{l}\text { PDMS, PMMA, PC } \\
\text { membrane }\end{array}$ & $3 \mathrm{D}$ & Flow, conditions, Matrigel & $\begin{array}{l}\text { HepG2, LX-2, } \\
\text { EAhy926, U937 }\end{array}$ & $\begin{array}{c}\text { Investigation of } \\
\text { pathophysiological } \\
\text { process of individual } \\
\text { non-parenchymal } \\
\text { cells in } \\
\text { alcohol-induced } \\
\text { ALD } \\
\end{array}$ & $\begin{array}{l}\text { ZO-1, CD14 and } \\
\text { F-actin, } \\
\text { VE-Cadherin, and } \\
\text { eNOS for EAhy926, } \\
\text { VEGF, and } \alpha \text {-SMA } \\
\text { for LX-2 }\end{array}$ & Albumin, urea, ROS & $\begin{array}{l}\text { Alcohol damages the tight } \\
\text { junction and reduces the } \\
\text { release of NO of EAhy926 cells }\end{array}$ & [99] \\
\hline PDMS & $2 \mathrm{D}$ & $\begin{array}{l}\text { static and flow, fibronectin } \\
\text { and collagen I }\end{array}$ & $\begin{array}{l}\text { Primary human } \\
\text { hepatocytes, LX-2, } \\
\text { EA.hy926, U937 }\end{array}$ & $\begin{array}{l}\text { Recapitulation of } \\
\text { a liver } \\
\text { sinusoid-on-a-chip }\end{array}$ & CD31 & $\begin{array}{l}\text { Albumin, urea, } \\
\text { CYP3A4 }\end{array}$ & $\begin{array}{l}\text { Higher albumin synthesis } \\
\text { (synthetic), urea excretion } \\
\text { (detoxification) was observed } \\
\text { under flow compared to } \\
\text { static cultures. }\end{array}$ & [100] \\
\hline
\end{tabular}


Table 3. Cont

\begin{tabular}{|c|c|c|c|c|c|c|c|c|}
\hline \multicolumn{5}{|c|}{ Device Specifics } & \multicolumn{2}{|c|}{ Assays } & \multicolumn{2}{|l|}{ Additional Information } \\
\hline Device Material & $2 \mathrm{D} / 3 \mathrm{D}$ & Culture Conditions & Cell Type(s) & Application & Staining & Assays & Outcome & Ref. \\
\hline PDMS & $2 \mathrm{D}$ & $\begin{array}{l}\text { static and flow conditions, } \\
\text { co-Culture of primary rat } \\
\text { hepatocytes and } \\
\text { endothelial cells }\end{array}$ & $\begin{array}{c}\text { Primary rat } \\
\text { hepatocytes, } \\
\text { primary rat adrenal } \\
\text { medullary } \\
\text { endothelial cells } \\
\text { (RAMECs), bovine } \\
\text { aortic endothelial } \\
\text { cells (BAECs) }\end{array}$ & $\begin{array}{l}\text { Analysis of viral } \\
\text { replication for the } \\
\text { hepatotropic } \\
\text { hepatitis B } \\
\text { virus (HBV) }\end{array}$ & - & $\begin{array}{c}\text { Urea, analysis of } \\
\text { secreted HBV, RT-PCR }\end{array}$ & $\begin{array}{l}\text { A dual-channel configuration } \\
\text { under flow condition seems to } \\
\text { be the best long-term liver } \\
\text { model and more closely mimics } \\
\text { the structure and } \\
\text { microenvironment of the } \\
\text { liver sinusoid. }\end{array}$ & [102] \\
\hline PDMS & $2 \mathrm{D} / 3 \mathrm{D}$ & $\begin{array}{c}\text { Flow conditions, } \\
\text { monolayer, collagen } \\
\text { sandwich, 3D spheroids, } \\
\text { bioreactor }\end{array}$ & $\begin{array}{l}\text { Primary rat } \\
\text { hepatocytes }\end{array}$ & $\begin{array}{l}\text { Assessment of } \\
\text { repeated dosing } \\
\text { chronic } \\
\text { hepatotoxicity }\end{array}$ & - & $\begin{array}{l}\text { Oxygen concentration, } \\
\text { shear stress, viability, } \\
\text { urea, albumin, } \\
\text { CYP1A2, CYP2B1/2, } \\
\text { CYP3A2 }\end{array}$ & $\begin{array}{l}\text { Chronic drug response to } \\
\text { repeated dosing of Diclofenac } \\
\text { and acetaminophen evaluated } \\
\text { in PIC were more sensitive } \\
\text { than the static culture control. }\end{array}$ & [215] \\
\hline PMMA & $2 \mathrm{D} / 3 \mathrm{D}$ & $\begin{array}{l}\text { Flow conditions, } \mathrm{dECM} \\
\text { bioink }\end{array}$ & HepaRG, HUVEC & $\begin{array}{l}\text { Vascular/biliary } \\
\text { fluidic channels for } \\
\text { creating vascular } \\
\text { and biliary systems }\end{array}$ & $\begin{array}{l}\text { MRP2, CK31, } \\
\text { Cholyllysyl- } \\
\text { fluorescein }\end{array}$ & $\begin{array}{l}\text { Albumin, urea, CYP } \\
\text { expression }\end{array}$ & $\begin{array}{l}\text { Drug treatment in the chip was } \\
\text { highly influential and that liver } \\
\text { functions were disrupted } \\
\text { during the culture }\end{array}$ & [216] \\
\hline PDMS & $3 \mathrm{D}$ & $\begin{array}{l}\text { Liver microsome into 3-D } \\
\text { hydrogel pillars }\end{array}$ & Rat liver microsomes & $\begin{array}{l}\text { Analyzing the } \\
\text { reaction kinetics } \\
\text { inside the } \\
\text { microfluidic chip by } \\
\text { liver enzymes }\end{array}$ & - & $\begin{array}{l}\text { P450 reactions, enzyme } \\
\text { kinetic parameters } \\
(\mathrm{Km}, \mathrm{Vm}, \text { Diffusivity })\end{array}$ & $\begin{array}{l}\text { Reaction rates were } \\
\text { significantly lower than the } \\
\text { solution phase mathematical } \\
\text { model that showed a good } \\
\text { correlation with the results }\end{array}$ & [93] \\
\hline Glass (Micronit) & $2 \mathrm{D}$ & Flow conditions, collagen I & $\begin{array}{l}\text { Primary human } \\
\text { hepatocytes, THP-1, } \\
\text { LX-2, HMVEC, } \\
\text { primary human } \\
\text { PMNs, LSECs }\end{array}$ & ADME/TOX studies & $\begin{array}{c}\text { F-actin, VE-cadherin, } \\
\alpha \text {-SMA }\end{array}$ & $\begin{array}{c}\text { Bile efflux, } \\
\text { permeability, ROS }\end{array}$ & $\begin{array}{l}\text { Partial immunologic functions } \\
\text { within the liver sinusoid, } \\
\text { including the activation of } \\
\text { LSECs, promoting the binding } \\
\text { of polymorphonuclear } \\
\text { leukocytes (PMNs) followed by } \\
\text { transmigration into the } \\
\text { hepatic chamber }\end{array}$ & [101] \\
\hline PDMS & $3 \mathrm{D}$ & $\begin{array}{l}\text { Flow conditions, 3D } \\
\text { spheroid culture }\end{array}$ & $\begin{array}{l}\text { Primary rat } \\
\text { hepatocytes, hepatic } \\
\text { stellate cells }\end{array}$ & $\begin{array}{l}\text { Investigation of } \\
\text { hepatocyte-hepatic } \\
\text { stellate cell } \\
\text { interactions }\end{array}$ & $\begin{array}{l}\text { Albumin, } \mathrm{P} 450 \\
\text { reductase }\end{array}$ & Albumin, urea & $\begin{array}{l}\text { Enzymatic activity of spheroids } \\
\text { co-cultured for } 8 \text { days was } \\
\text { greater than that of } \\
\text { mono-cultured spheroids }\end{array}$ & [97] \\
\hline
\end{tabular}


Table 3. Cont

\begin{tabular}{|c|c|c|c|c|c|c|c|c|}
\hline \multicolumn{5}{|c|}{ Device Specifics } & \multicolumn{2}{|c|}{ Assays } & \multicolumn{2}{|l|}{ Additional Information } \\
\hline Device Material & 2D/3D & Culture Conditions & Cell Type(s) & Application & Staining & Assays & Outcome & Ref. \\
\hline $\begin{array}{l}\text { PMMA, PDMS, PC } \\
\text { membrane }\end{array}$ & $3 \mathrm{D}$ & $\begin{array}{l}\text { flow conditions, 3D } \\
\text { spheroid culture }\end{array}$ & human HepG2/C3A & $\begin{array}{c}\text { development of } \\
\text { bio-artificial livers, } \\
\text { disease modeling, } \\
\text { and drug toxicity } \\
\text { screening }\end{array}$ & $\begin{array}{l}\text { ZO-1, MRP-2, CPR, } \\
\text { NADPH- } \\
\text { cytochrome P450 } \\
\text { reductase }\end{array}$ & $\begin{array}{l}\text { Albumin, urea, } \\
\text { expression of CYP } \\
\text { enzymes, phase II } \\
\text { enzymes, hepatic } \\
\text { nuclear receptors, } \\
\text { hepatic transporters, } \\
\text { bile canaliculi } \\
\text { transporters }\end{array}$ & $\begin{array}{l}\text { timesaving, efficient, and safe } \\
\text { in situ perfusion culture of } \\
\text { hepatic spheroids in 3D culture }\end{array}$ & [217] \\
\hline
\end{tabular}

Table 4. Kidney-on-a-chip applications.

\begin{tabular}{|c|c|c|c|c|c|c|c|c|}
\hline \multicolumn{2}{|c|}{ Device Specifics } & \multicolumn{2}{|c|}{ Assays } & \multicolumn{2}{|c|}{ Additional Information } & \multicolumn{3}{|c|}{-} \\
\hline Device Material & $2 \mathrm{D} / 3 \mathrm{D}$ & Culture Conditions & Cell Type & Application & Staining & Assay & Outcome & Ref. \\
\hline PDMS & $\begin{array}{l}\text { 2D, human proximal } \\
\text { tubule }\end{array}$ & $\begin{array}{l}\text { Flow conditions, 2D } \\
\text { on collagen type I }\end{array}$ & $\begin{array}{l}\text { Human primary } \\
\text { proximal tubular } \\
\text { epithelial cells } \\
\text { (PTECs) }\end{array}$ & $\begin{array}{l}\text { Renal drug clearance } \\
\text { and drug-induced } \\
\text { nephrotoxicity }\end{array}$ & $\begin{array}{c}\text { CD13, E-cadherin, } \\
\text { aquaporin 1, } \\
\text { prominin 2, } \\
\text { uromodulin, KIM-1, } \\
\text { Na+/K+ ATPase, } \\
\text {-glutamyl } \\
\text { transpeptidase } \\
\text { (GGT) }\end{array}$ & $\begin{array}{c}\gamma \text {-Glutamyl } \\
\text { transpeptidase } \\
\text { (GGT) activity, ATP } \\
\text { assay, } \\
\text { ammoniagenesis, } \\
\text { glucose reabsorption } \\
\text { 25-(OH)2, vitamin } \\
\text { D3 metabolism }\end{array}$ & $\begin{array}{l}\text { Morphological and functional } \\
\text { phenotypes of proximal tubule } \\
\text { epithelium in vivo }\end{array}$ & [110] \\
\hline PDMS & $\begin{array}{c}\text { Glomerular vascular } \\
\text { system }\end{array}$ & $\begin{array}{l}\text { Flow conditions, } \\
\text { ECM with } \\
\text { fibrinogen, } 2 \mathrm{wt} \% \\
\text { gelatin, } 2.5 \mathrm{mM} \\
\mathrm{CaCl}_{2} \text {, and } 0.2 \mathrm{wt} \% \\
\text { transglutaminase }\end{array}$ & $\begin{array}{l}\text { hPSC-derived } \\
\text { kidney pretubular } \\
\text { aggregates }\end{array}$ & $\begin{array}{l}\text { nephrotoxicity, } \\
\text { tubular and } \\
\text { glomerular disease, } \\
\text { and kidney } \\
\text { regeneration }\end{array}$ & $\begin{array}{c}\text { DNA, MCAM, } \\
\text { PECAM1, PODXL, } \\
\text { PDGFR } \beta, \text { TUBA4A, } \\
\text { ATP1A1 (Na/K } \\
\text { ATPase subunit- } \alpha 1) \text {, } \\
\text { collagen IV and LTL }\end{array}$ & $\begin{array}{c}\text { Flow profile analysis, } \\
\text { flow cytometry, } \\
\text { qRT-PCR }\end{array}$ & $\begin{array}{l}\text { Vascularized kidney organoids } \\
\text { cultured under flow had more mature } \\
\text { podocyte and tubular compartments } \\
\text { with enhanced cellular polarity and } \\
\text { adult gene expression ompared with } \\
\text { that in static controls }\end{array}$ & [113] \\
\hline
\end{tabular}


Table 4. Cont.

\begin{tabular}{|c|c|c|c|c|c|c|c|c|}
\hline \multicolumn{2}{|c|}{ Device Specifics } & \multicolumn{2}{|c|}{ Assays } & \multicolumn{2}{|c|}{ Additional Information } & \multicolumn{3}{|c|}{-} \\
\hline Device Material & $2 \mathrm{D} / 3 \mathrm{D}$ & Culture Conditions & Cell Type & Application & Staining & Assay & Outcome & Ref. \\
\hline $\begin{array}{l}\text { Polysterene } \\
\text { (Mimetas) }\end{array}$ & $\begin{array}{l}\text { 3D, proximal tubule } \\
\text { microvillus }\end{array}$ & $\begin{array}{l}\text { Flow conditions, } \\
\text { ECM, Collagen I }\end{array}$ & $\begin{array}{l}\text { Cortical kidney } \\
\text { tissue, urine-derived } \\
\text { kidney cells }\end{array}$ & $\begin{array}{l}\text { Personalized } \\
\text { medicine }\end{array}$ & $\begin{array}{l}\text { ZO-1, Ezrin, CDH-1, } \\
\text { tubulin, }\end{array}$ & $\begin{array}{l}\text { Barrier integrity } \\
\text { assayP-gp } \\
\text { transporter assay, } \\
\text { trans-epithelial } \\
\text { transport assay }\end{array}$ & $\begin{array}{l}\text { Tubuloid-derived cells can form } \\
\text { leak-tight, polarized kidney tubules, } \\
\text { enabling personalized transporter } \\
\text { studies in tubuloids }\end{array}$ & [218] \\
\hline Acryl chambers & $\begin{array}{l}\text { 2D, glomerular filter } \\
\text { barrier }\end{array}$ & $\begin{array}{l}\text { Flow conditions, } \\
\text { collagen I on porous } \\
\text { membrane } 0.02 \mu \mathrm{m} \\
\text { pore size }\end{array}$ & $\begin{array}{l}\text { Immortalized } \\
\text { podocytes }\end{array}$ & $\begin{array}{c}\text { transmembrane } \\
\text { pressure in } \\
\text { glomerular filter } \\
\text { membrane, with } \\
\text { potential } \\
\text { implications for drug } \\
\text { development }\end{array}$ & Actin & $\begin{array}{l}\text { Dextran filtration, } \\
\text { qPCR }\end{array}$ & $\begin{array}{l}\text { Dysfunction of renal filtration is } \\
\text { correlated with the reduction of } \\
\text { synaptopodin expression and } \\
\text { disorganized actin cytoskeleton }\end{array}$ & [219] \\
\hline $\begin{array}{l}\text { Polysterene } \\
\text { (Mimetas) }\end{array}$ & $2 \mathrm{D}$ and $3 \mathrm{D}$ & $\begin{array}{l}\text { Flow conditions, 3D } \\
\text { ECM Collagen I }\end{array}$ & $\begin{array}{l}\text { Immortalized } \\
\text { proximal tubule } \\
\text { epithelial cells } \\
\text { (CiPTEC-OAT1) }\end{array}$ & $\begin{array}{l}\text { Screenings assay for } \\
\text { renal } \\
\text { drug-transporter } \\
\text { interactions }\end{array}$ & $\begin{array}{l}\text { ZO-1, tubulin, } \\
\text { pericentrin }\end{array}$ & $\begin{array}{l}\text { Functionality of P-gp } \\
\text { and MRP2/4 }\end{array}$ & $\begin{array}{l}\text { Increased accumulation of } \\
\text { glutathione-methylfluorescein } \\
\text { (GS-MF) was observed upon } \\
\text { inhibition with a combination of } \\
\text { PSC833, MK571, and KO143 }\end{array}$ & [220] \\
\hline PDMS & $2 \mathrm{D}$ & $\begin{array}{l}\text { Matrigel-coated, } \\
\text { flow and static } \\
\text { conditions }\end{array}$ & $\begin{array}{c}\text { ureteric bud (UB) } \\
\text { cells isolated from } \\
\text { primary mouse } \\
\text { embryonic kidneys } \\
\text { cells }\end{array}$ & $\begin{array}{c}\text { Fluid shear stress } \\
\text { studies }\end{array}$ & $\begin{array}{l}\text { Dolichosbiflorus } \\
\text { agglutinin }\end{array}$ & qRT-PCR & $\begin{array}{l}\text { Link between the fluid shear stress } \\
\text { from the initiation of urine flow and } \\
\text { the development and function of } \\
\text { the kidney }\end{array}$ & [221] \\
\hline PDMS & $\begin{array}{l}\text { Kidney glomerular } \\
\text { capillary wall }\end{array}$ & $\begin{array}{l}\text { Flow conditions, } \\
\text { Matrigel coated }\end{array}$ & $\begin{array}{l}\text { PS cells (PGP1, } \\
\text { IMR-90-1, and } \\
\text { IISH3i-CB6) and ES } \\
\text { cell (H9) lines }\end{array}$ & $\begin{array}{c}\text { Podocyte } \\
\text { differentiation }\end{array}$ & podocin & $\begin{array}{l}\text { Whole- } \\
\text { transcriptome } \\
\text { analysis }\end{array}$ & $\begin{array}{l}\text { Podocyte differentiation protocol for } \\
\text { iPS cells, and the development of a } \\
\text { glomerulus chip }\end{array}$ & [222] \\
\hline $\mathrm{COP}$ & $2 \mathrm{D}$ & $\begin{array}{l}\text { Flow conditions PET } \\
\text { membrane, coated } \\
\text { with collagen type I }\end{array}$ & $\begin{array}{l}\text { Renal epithelial cells } \\
\text { (raTAL and } \\
\text { NRK-52E) }\end{array}$ & $\begin{array}{l}\text { Transepithelial } \\
\text { reabsorption of } \mathrm{NaCl}\end{array}$ & - & TEER & $\begin{array}{l}\text { RaTAL cells might sense ion } \\
\text { concentrations on either side and } \\
\text { adjust tight junction } \\
\text { permeability accordingly. }\end{array}$ & [223] \\
\hline
\end{tabular}


Table 5. Heart-on-a-chip applications.

\begin{tabular}{|c|c|c|c|c|c|c|c|}
\hline & & Device Specifics & & & Assays & Additional Information & \\
\hline Organ(s) & Device Material & Application & Cell Type & 2D/3D & Sensing Principle & Outcome & Ref. \\
\hline Heart and liver & $\begin{array}{l}\text { PMMA, PDMS, } \\
\text { titanium, platinum } \\
\text { (electrodes) }\end{array}$ & $\begin{array}{c}\text { Cardiotoxicity } \\
\text { (primarily from hepatic } \\
\text { cytochrome P450 (CYP) } \\
\text { metabolism) }\end{array}$ & $\begin{array}{l}\text { Human iPSC derived } \\
\text { cardiomyocytes and } \\
\text { human primary } \\
\text { hepatocytes }\end{array}$ & 2D monolayers & $\begin{array}{l}\text { Multi-electrode array for } \\
\text { electrical activity sensing and } \\
\text { cantilever array for sensing of } \\
\text { cardiac mechanical function }\end{array}$ & $\begin{array}{l}\text { Culture period of } 28 \text { days with } \\
\text { stable cellular function/viability. } \\
\text { Cardiotoxicity of two known } \\
\text { drugs due to hepatic metabolism } \\
\text { could be predicted. }\end{array}$ & [224] \\
\hline Heart & $\begin{array}{l}\text { PDMS, titanium, } \\
\text { palladium, gold } \\
\text { (electrodes) }\end{array}$ & $\begin{array}{l}\text { Cardiac biomarker } \\
\text { secretion }\end{array}$ & $\begin{array}{l}\text { Human embryonic stem } \\
\text { cell-derived } \\
\text { cardiomyocytes }\end{array}$ & $\begin{array}{c}\text { 3D cell-laden } \\
\text { hydrogel structures }\end{array}$ & $\begin{array}{l}\text { Creatine kinase (CK)-MB } \\
\text { sensing by impedance } \\
\text { measurements using an } \\
\text { aptamer functionalized } \\
\text { micro-electrode }\end{array}$ & $\begin{array}{l}\text { Aptamers specific to cardiac } \\
\text { damage markers could detect } \\
\text { dose-dependent usage of drugs. } \\
\text { Beating rate and cell viability } \\
\text { confirmed these measurements. }\end{array}$ & [225] \\
\hline Blood vessel, heart, liver & PDMS, polystyrene & Cancer metastasis & $\begin{array}{l}\text { HUVECs, HepG2, and } \\
\text { hPSC line BJ1D }\end{array}$ & $\begin{array}{l}\text { 3D cell-laden hydrogel } \\
\text { structures }\end{array}$ & $\begin{array}{c}\text { Cardiac beat frequency } \\
\text { sensing by fluorescence } \\
\text { microscopy and } \\
\text { computational analysis of } \\
\text { micro-cantilevers. }\end{array}$ & $\begin{array}{l}\text { Simulation of cancer invasion and } \\
\text { metastasis from tumor to } \\
\text { downstream liver model. }\end{array}$ & [226] \\
\hline Heart & $\begin{array}{l}\text { PDMS, titanium, } \\
\text { platinum (electrodes) }\end{array}$ & $\begin{array}{l}\text { Barrier function and } \\
\text { electrical activity of } \\
\text { endothelialized } \\
\text { myocardium }\end{array}$ & $\begin{array}{l}\text { HUVECs and human } \\
\text { iPSC derived } \\
\text { cardiomyocytes }\end{array}$ & Barrier model & $\begin{array}{l}\text { Barrier integrity and electrical } \\
\text { activity sensing by } \\
\text { TEER-multielectrode array } \\
\text { measurements }\end{array}$ & $\begin{array}{l}\text { Measurement of biological } \\
\text { processes and drug effects by } \\
\text { TEER and MEA, allowing analysis } \\
\text { of barrier function, changes in cell } \\
\text { layer conformation, and } \\
\text { electrical activity. }\end{array}$ & [208] \\
\hline Heart and liver & $\begin{array}{l}\text { PDMS, gold, silver } \\
\text { (electrodes) }\end{array}$ & Organ toxicity & $\begin{array}{l}\text { Human iPSC derived } \\
\text { cardiomyocytes and } \\
\text { HepG2/C3A } \\
\text { hepatocellular } \\
\text { carcinoma cells }\end{array}$ & 3D organoids & $\begin{array}{l}\text { pH sensing by light } \\
\text { absorption of phenol red, } \\
\text { oxygen sensing by } \\
\text { fluorescence measurements of } \\
\text { quenching effects of oxygen } \\
\text { sensitive ruthenium dye and } \\
\text { immunosensing by } \\
\text { functionable electrodes }\end{array}$ & $\begin{array}{c}\text { Platform for automated } \\
\text { measurement of } \mathrm{pH} \text {, oxygen, } \\
\text { temperature, and biomarkers and } \\
\text { microscope imaging over a period } \\
\text { of } 5 \text { days of a dual organ-on-a-chip } \\
\text { system with and without drug } \\
\text { inducement. }\end{array}$ & [207] \\
\hline Heart & $\begin{array}{l}\text { PDMS, carbon } \\
\text { (electrodes) }\end{array}$ & $\begin{array}{l}\text { Beating behavior, } \\
\text { cardiotoxicity }\end{array}$ & $\begin{array}{c}\text { Cardiomyocytes } \\
\text { isolated from neonatal } \\
\text { Sprague Dawley rat } \\
\text { pups }\end{array}$ & $\begin{array}{l}\text { 3D cell-laden hydrogel } \\
\text { structures }\end{array}$ & $\begin{array}{l}\text { Generated force sensing by } \\
\text { fluorescence measurement of } \\
\text { deflection of cantilevers }\end{array}$ & $\begin{array}{l}\text { Generated cardiac microtissues } \\
\text { showed that mechanical response } \\
\text { (dynamic response, spontaneous } \\
\text { stress) to compounds } \\
\text { (isoproterenol and digoxin) can be } \\
\text { used for drug testing }\end{array}$ & [227] \\
\hline
\end{tabular}


Table 5. Cont.

\begin{tabular}{|c|c|c|c|c|c|c|c|}
\hline & & Device Specifics & & & Assays & Additional Information & \\
\hline Organ(s) & Device Material & Application & Cell Type & 2D/3D & Sensing Principle & Outcome & Ref. \\
\hline Heart & PDMS & $\begin{array}{l}\text { Beating behavior, } \\
\text { cardiotoxicity }\end{array}$ & $\begin{array}{l}\text { Human iPSC derived } \\
\text { cardiomyocytes }\end{array}$ & $\begin{array}{c}\text { Small (100 } \mu \mathrm{m} \text { height) } \\
\text { 3D cell-laden hydrogel } \\
\text { structures }\end{array}$ & $\begin{array}{l}\text { Beat rate, conduction velocity, } \\
\text { and field potential duration } \\
\text { were measured by field } \\
\text { potential analysis using } \\
\text { commercially available MEAs }\end{array}$ & $\begin{array}{l}\text { The micro-molded gelatin system } \\
\text { with incorporated MEAs is able to } \\
\text { measure electrophysiological } \\
\text { changes in the cardiac tissue. Beat } \\
\text { rate responded accordingly to } \\
\text { drug (isoproterenol) application. }\end{array}$ & [228] \\
\hline Heart, liver, and lung & $\begin{array}{l}\text { PDMS, PMMA, gold } \\
\text { (electrodes) }\end{array}$ & Organ toxicity & $\begin{array}{l}\text { Hepatic stellate cells, } \\
\text { primary human } \\
\text { hepatocytes, Kupffer } \\
\text { cells, iPSC-derived } \\
\text { cardiomyocytes, human } \\
\text { primary cardiac } \\
\text { fibroblasts, lung } \\
\text { microvasculature } \\
\text { endothelial cells, airway } \\
\text { stromal mesenchymal } \\
\text { cells, and bronchial } \\
\text { epithelial cells }\end{array}$ & 3D organoids & $\begin{array}{c}\text { Cardiac beat rate } \\
\text { measurement by real-time } \\
\text { imaging and computational } \\
\text { analysis, antibody-binding by } \\
\text { impedance measurement and } \\
\text { barrier function by TEER } \\
\text { measurement }\end{array}$ & $\begin{array}{l}\text { The impact of multi-organ } \\
\text { crosstalk is displayed by the } \\
\text { effects of bleomycin on the cardiac } \\
\text { tissue with and without a lung } \\
\text { tissue present. }\end{array}$ & [209] \\
\hline $\begin{array}{l}\text { Heart, liver, skeletal } \\
\text { muscle, and neuronal } \\
\text { network }\end{array}$ & $\begin{array}{l}\text { PDMS, PMMA, } \\
\text { Titanium, platinum } \\
\text { (electrodes) }\end{array}$ & Organ toxicity & $\begin{array}{l}\text { Human hepatocellular } \\
\text { carcinoma HepG2/C3A, } \\
\text { human iPSC derived } \\
\text { cardiomyocytes, human } \\
\text { skeletal myofibers, } \\
\text { human motorneurons } \\
\text { differentiated from } \\
\text { human spinal cord stem } \\
\text { cell line (hSCSC) and } \\
\text { human iPSC dervied } \\
\text { cortical-like neurons }\end{array}$ & 2D monolayers & $\begin{array}{l}\text { Cardiomyocyte contraction } \\
\text { (force) sensing by cantilever } \\
\text { deflection (laser beam } \\
\text { reflection) }{ }^{10,11} \text { and electrical } \\
\text { activity of cardiomyocytes or } \\
\text { motoneurons by a } \\
\text { multielectrode array }\end{array}$ & $\begin{array}{l}\text { The system could detect influences } \\
\text { of organ-cross talk in drug testing } \\
\text { over a period of } 14 \text { days. }{ }^{10} \\
\text { The } 4 \text {-organ-system revealed } \\
\text { stable conditions for all organs } \\
\text { over a period of } 28 \text { days, making it } \\
\text { a good fit for drug testing to } \\
\text { investigate repeat dose toxicity. }\end{array}$ & [229] \\
\hline Heart & $\begin{array}{l}\text { Petri dish as housing for } \\
\text { MEA, titanium } \\
\text { (electrodes) }\end{array}$ & Beating behavior & $\begin{array}{l}\text { Human embryoid stem } \\
\text { cell line CCTL14 and } \\
\text { human iPSCs }\end{array}$ & 3D organoid & $\begin{array}{l}\text { Cardiomyocyte beating force } \\
\text { sensing by multi-electrode } \\
\text { array and atomic force } \\
\text { microscopy measurements }\end{array}$ & $\begin{array}{l}\text { The system was able to determine } \\
\text { the relation between cardiac } \\
\text { beating behavior and correlated } \\
\text { force in case of Duchenne } \\
\text { Muscular Dystrophy. }\end{array}$ & [208] \\
\hline
\end{tabular}


Table 5. Cont.

\begin{tabular}{|c|c|c|c|c|c|c|c|}
\hline \multicolumn{5}{|c|}{ Device Specifics } & \multirow{2}{*}{$\begin{array}{c}\text { Assays } \\
\text { Sensing Principle }\end{array}$} & \multicolumn{2}{|l|}{ Additional Information } \\
\hline Organ(s) & Device Material & Application & Cell Type & $2 \mathrm{D} / 3 \mathrm{D}$ & & Outcome & Ref. \\
\hline $\begin{array}{l}\text { Embryoid body (cardiac } \\
\text { cells) }\end{array}$ & $\begin{array}{l}\text { Glass, PEDOT:PSS } \\
\text { (electrodes) }\end{array}$ & $\begin{array}{l}\text { Autonomous beat rate } \\
\text { of embryoid bodies }\end{array}$ & $\begin{array}{l}\text { Mouse embryonic stem } \\
\text { cells (mESC) derived } \\
\text { cardiomyocytes }\end{array}$ & 3D embryoid body & $\begin{array}{l}\text { Cardiac beat rate sensing by } \\
\text { voltage and displacement } \\
\text { current measurement by large } \\
\text { area electrodes }\end{array}$ & $\begin{array}{l}\text { The system could measure the } \\
\text { beating rate of whole embryoid } \\
\text { bodies due to a combination of } \\
\text { large, high capacity electrodes and } \\
\text { usage of the displacement current } \\
\text { measurement technique. }\end{array}$ & [230] \\
\hline Heart & $\begin{array}{l}\text { Glass, PDMS, poly(N- } \\
\text { isopropylacrylamide)(PIPA } \\
\text { platinum (electrodes) }\end{array}$ & Andy/uscle contraction & $\begin{array}{c}\text { Cardiac ventricular } \\
\text { myocytes harvested } \\
\text { from two-day old } \\
\text { neonatal } \\
\text { Sprague-Dawley rats }\end{array}$ & 2D monolayer & $\begin{array}{l}\text { Cardiac tissue } \\
\text { stress/contraction sensing by } \\
\text { measurement of deformation } \\
\text { of cells on elastic, thin film }\end{array}$ & $\begin{array}{l}\text { Measurement of spontaneous } \\
\text { contraction of cardiac tissues due } \\
\text { to the impact of epinephrine. }\end{array}$ & [27] \\
\hline Heart & $\begin{array}{l}\text { PDMS, copper (force } \\
\text { probe) }\end{array}$ & $\begin{array}{c}\text { Muscle } \\
\text { contraction/strength }\end{array}$ & $\begin{array}{l}\text { Myocytes isolated from } \\
\text { 0-2-day-old neonatal } \\
\text { Sprague-Dawley rats, } \\
\text { cardiac fibroblasts, and } \\
\text { a transfected human } \\
\text { embryonic kidney } \\
\text { (HEK) 293T }\end{array}$ & $\begin{array}{l}\text { 3D cell-laden hydrogel } \\
\text { fibers }\end{array}$ & $\begin{array}{l}\text { Force sensing of the muscle } \\
\text { strips by usage of a copper } \\
\text { force probe, which applied } \\
\text { force/deformation prior to the } \\
\text { illumination. The deformation } \\
\text { prior to and after the } \\
\text { illumination was compared }\end{array}$ & $\begin{array}{l}\text { The system was able to } \\
\text { individually activate and pace the } \\
\text { muscle fibers. With the addition of } \\
\text { multiple fibers, the force can be } \\
\text { graded. This offers a non-invasive } \\
\text { way (compared to electrodes) for } \\
\text { muscle stimulation. }\end{array}$ & [25] \\
\hline Heart & $\begin{array}{l}\text { PDMS, polystyrene } \\
\text { beads (cyclic strain } \\
\text { measurement) }\end{array}$ & $\begin{array}{l}\text { Cardiac differentiation } \\
\text { under cyclic strain }\end{array}$ & $\begin{array}{l}\text { Neonatal rat cardiac } \\
\text { cells and human } \\
\text { iPSC-derived } \\
\text { cardiomyocytes }\end{array}$ & $\begin{array}{l}\text { 3D cell-laden hydrogel } \\
\text { structures }\end{array}$ & $\begin{array}{l}\text { Cellular property sensing by } \\
\text { immunofluorescence } \\
\text { (live/dead, histochemistry) } \\
\text { and scanning/transmission } \\
\text { electron microscopy }\end{array}$ & $\begin{array}{l}\text { The device showed that by } \\
\text { applying cyclic strain, the cell-cell } \\
\text { and cell-matrix interactions are } \\
\text { better, and also micro-tissues } \\
\text { displayed early synchronous } \\
\text { beating. }\end{array}$ & [126] \\
\hline Heart & $\begin{array}{l}\text { Dextran, elastollan, } \\
\text { silver flakes, PDMS }\end{array}$ & $\begin{array}{l}\text { Long-term non-invasive } \\
\text { measurement of } \\
\text { contractile strength of } \\
\text { cardiac tissues }\end{array}$ & $\begin{array}{l}\text { Neonatal rat ventricular } \\
\text { myocytes (NRVMs) and } \\
\text { human iPSC-derived } \\
\text { cardiomyocytes }\end{array}$ & Multiple 2D monolayers & $\begin{array}{l}\text { Contractile stress and beat rate } \\
\text { sensing by relative resistance } \\
\text { changes of embedded sensors }\end{array}$ & $\begin{array}{l}\text { 3D multi-material printing } \\
\text { allowed the creation of a device } \\
\text { for non-invasive measurement of } \\
\text { contractile stress development } \\
\text { over a period of } 4 \text { weeks. }\end{array}$ & [130] \\
\hline
\end{tabular}


Table 5. Cont.

\begin{tabular}{|c|c|c|c|c|c|c|c|}
\hline \multicolumn{5}{|c|}{ Device Specifics } & \multirow{2}{*}{$\begin{array}{c}\text { Assays } \\
\text { Sensing Principle } \\
\end{array}$} & \multicolumn{2}{|l|}{ Additional Information } \\
\hline Organ(s) & Device Material & Application & Cell Type & 2D/3D & & Outcome & Ref. \\
\hline Heart & $\begin{array}{l}\text { PDMS, glass, poly(3,4- } \\
\text { ethylenedioxythiophene) } \\
\text { carbon nanotube } \\
\text { (PEDOT-CNT) } \\
\text { (electrodes); UV } \\
\text { crosslinkable } \\
\text { methacrylated gelatin } \\
\text { (GelMA) }\end{array}$ & $\begin{array}{c}\text { On-chip culture of } \\
\text { human 3D myocardium } \\
\text { using cells from a single } \\
\text { patient }\end{array}$ & $\begin{array}{l}\text { Human iPSC-derived } \\
\text { myocardial cells and } \\
\text { endothelial cells }\end{array}$ & $\begin{array}{l}\text { 3D cell-laden hydrogel } \\
\text { structures }\end{array}$ & $\begin{array}{l}\text { Cell population alignment } \\
\text { sensing by microscopy and } \\
\text { beating frequency sensing by } \\
\text { measurement of extracellular } \\
\text { membrane potential }\end{array}$ & $\begin{array}{l}\text { Usage of two cell types derived } \\
\text { from the same hiPSCs this device } \\
\text { mimics the myocardium of an } \\
\text { individual human. Integration of } \\
\text { hydrogel allowed 3D structuring } \\
\text { and analysis was performed by } \\
\text { integrated micro-electrode arrays } \\
\text { and standard cell culture analysis. }\end{array}$ & [121] \\
\hline Heart & $\begin{array}{l}\text { Polydopamine (PDA), } \\
\text { polycaprolactone (PCL) } \\
\text { (nanofibers), gelatin } \\
\text { (cantilever), TiO2, and } \\
\mathrm{Ag} \text { (nanoparticels) }\end{array}$ & Contractile activity & $\begin{array}{l}\text { Neonatal rat ventricular } \\
\text { myocytes (NRVMs) } \\
\text { isolated from 2-day-old } \\
\text { Sprague Dawley rats }\end{array}$ & 2D monolayer & $\begin{array}{c}\text { Beat rate sensing by optical } \\
\text { detection of cantilever } \\
\text { deflection }\end{array}$ & $\begin{array}{l}\text { By using 3D fiber scaffolds, the } \\
\text { device supported the formation of } \\
\text { anisotropic and contractile cardiac } \\
\text { tissues. Non-invasive } \\
\text { measurement of nanoparticle } \\
\text { impact enables good drug } \\
\text { screening capabilities. }\end{array}$ & [128] \\
\hline Heart & $\begin{array}{l}\text { Quartz (substrate), gold } \\
\text { (electrodes) }\end{array}$ & Beating behavior & $\begin{array}{l}\text { Neonatal rat } \\
\text { cardiomyocytes }\end{array}$ & 2D monolayer & $\begin{array}{l}\text { Beat rate and amplitude } \\
\text { sensing by impedance } \\
\text { detection }\end{array}$ & $\begin{array}{l}\text { The device can measure the } \\
\text { mechanical contraction status of } \\
\text { the cardiac tissue, which can be } \\
\text { linked to the pumping of blood } \\
\text { and plays a vital role in drug } \\
\text { screening for heart medication. }\end{array}$ & [123] \\
\hline Heart & $\begin{array}{l}\text { PMMA, alginate, } \\
\text { gelatin methacryloyl } \\
\text { (GelMA), photoinitiator } \\
\text { Irgacure } 2959 \text { (bioink) }\end{array}$ & Contractile activity & $\begin{array}{l}\text { HUVECs, GFP-labeled } \\
\text { HUVECs, } \\
\text { and neonatal } \\
\text { cardiomyocytes isolated } \\
\text { from two-day-old } \\
\text { Sprague-Dawley rats }\end{array}$ & $\begin{array}{l}\text { 3D bioprinted } \\
\text { endothelial structure } \\
\text { with } 2 \mathrm{D} \text { cardiac } \\
\text { monolayer on top }\end{array}$ & $\begin{array}{l}\text { Beat rate and amplitude } \\
\text { sensing by optical microscopy } \\
\text { and computational analysis }\end{array}$ & $\begin{array}{l}\text { The endothelial cells in the } \\
\text { bio-printed fibers of the scaffold } \\
\text { would migrate toward the edge of } \\
\text { the fibers and form a layer of } \\
\text { confluent endothelium, mimicking } \\
\text { a blood vessel. In combination } \\
\text { with the myocardium and a } \\
\text { perfusion bioreactor, this was then } \\
\text { used for drug screening. }\end{array}$ & [132] \\
\hline
\end{tabular}


Table 5. Cont.

\begin{tabular}{|c|c|c|c|c|c|c|c|}
\hline & & Device Specifics & & & Assays & Additional Information & \\
\hline Organ(s) & Device Material & Application & Cell Type & 2D/3D & Sensing Principle & Outcome & Ref. \\
\hline Heart & $\begin{array}{l}\text { PEG-silane, PDMS, } \\
\text { silicon (cantilever) }\end{array}$ & $\begin{array}{l}\text { Electrical and } \\
\text { contractile activity }\end{array}$ & $\begin{array}{l}\text { Human cardiomyocytes } \\
\text { derived from the } \\
\text { hESC-10-0061 stem cell } \\
\text { line }\end{array}$ & 2D monolayer & $\begin{array}{l}\text { Electrical activity sensing by } \\
\text { using an MEA and contractile } \\
\text { stress sensing using } \\
\text { cantilevers deflection } \\
\text { measured by a photodiode } \\
\text { laser and a photodetector. }\end{array}$ & $\begin{array}{l}\text { The system is able to detect } \\
\text { electrical and contractile activity } \\
\text { of cardiac tissues and both sensing } \\
\text { areas can be upscaled. }\end{array}$ & [131] \\
\hline Heart & PDMS, glass & $\begin{array}{l}\text { Cell } \\
\text { proliferation/viability } \\
\text { increase in 3D vs 2D }\end{array}$ & $\begin{array}{l}\text { Human primary } \\
\text { cardiomyocytes }\end{array}$ & $\begin{array}{l}\text { 3D cell-laden hydrogel } \\
\text { structures, } 2 \mathrm{D} \\
\text { monolayer }\end{array}$ & $\begin{array}{l}\text { Cell proliferation and viability } \\
\text { sensing by fluorescence } \\
\text { microscopy }\end{array}$ & $\begin{array}{l}\text { The device showed that the } \\
\text { proliferation rate was higher in } 3 \mathrm{D} \\
\text { and the negative effects of } \\
\text { isoproterenol was lower in 3D. }\end{array}$ & [122] \\
\hline
\end{tabular}

Table 6. Vascularization-on-chip applications.

\begin{tabular}{|c|c|c|c|c|c|c|c|c|c|}
\hline \multicolumn{6}{|c|}{ Device Specifics } & \multirow{2}{*}{$\begin{array}{l}\text { Assays } \\
\text { Assays }\end{array}$} & \multicolumn{3}{|c|}{ Additional Information } \\
\hline Method & Device Material & Hydrogel & Concentration & Cell Source & Cell Type(s) & & Application & Outcome & Ref \\
\hline \multirow{4}{*}{$\begin{array}{l}\text { Microchannel } \\
\text { patterning }\end{array}$} & PDMS & Collagen 1 & $\begin{array}{l}0.1 \mathrm{mg} / \mathrm{mL} \\
\text { (coating) }\end{array}$ & Primary & HUVEC & $\begin{array}{l}\text { Live/dead staining } \\
\text { Immunofluorescence } \\
\text { staining Blood perfusion }\end{array}$ & Thrombosis & $\begin{array}{l}\text { Thrombosis-on-chip model } \\
\text { created by PDMS molding of } \\
\text { 3D-printed healthy and } \\
\text { stenotic vessel }\end{array}$ & [139] \\
\hline & PDMS & PDL/fibronectin & $\begin{array}{l}1 \mathrm{mg} / \mathrm{mL} \\
\text { (coating) }\end{array}$ & Primary & $\begin{array}{l}\text { VSMC } \\
\text { HUVEC }\end{array}$ & $\begin{array}{l}\text { Immunofluorescence } \\
\text { staining }\end{array}$ & $\begin{array}{l}\text { Platform for blood } \\
\text { vessel-related diseases }\end{array}$ & $\begin{array}{l}\text { Successful cultivation of } \\
\text { SMC and HUVEC on } \\
\text { micro-wrinkled PDMS }\end{array}$ & [140] \\
\hline & Hydrogels & $\begin{array}{l}\text { Alginate } \\
\text { Gelatin } \\
\text { Gel-MA }\end{array}$ & $\begin{array}{l}1-5 \% \\
1-9 \% \\
1-9 \%\end{array}$ & Primary & HUVEC & Diffusional permeability & $\begin{array}{c}\text { Enhancing physiological } \\
\text { relevance via } \\
\text { microfabrication of } \\
\text { hydrogels }\end{array}$ & $\begin{array}{c}\text { Hydrogel-based microfluidic } \\
\text { device as a } \\
\text { vessel-on-chip model }\end{array}$ & [143] \\
\hline & Gelatin & Gelatin & $9 \%$ & Primary & HUVEC & $\begin{array}{l}\text { Immunofluorescence } \\
\text { staining } \\
\text { Diffusional permeability }\end{array}$ & $\begin{array}{l}\text { Circular microfluidic } \\
\text { channels }\end{array}$ & $\begin{array}{c}\text { Fabrication of branched } \\
\text { vascular networks in a } \\
\text { hydrogel-based } \\
\text { microfluidic device }\end{array}$ & [144] \\
\hline
\end{tabular}


Table 7. Vascularization-on-chip applications.

\begin{tabular}{|c|c|c|c|c|c|c|c|c|c|}
\hline \multicolumn{6}{|c|}{ Device Specifics } & \multirow{2}{*}{$\begin{array}{l}\text { Assays } \\
\text { Assays }\end{array}$} & \multicolumn{3}{|c|}{ Additional Information } \\
\hline Method & Device Material & Hydrogel & Concentration & Cell Source & Cell Type(s) & & Application & Outcome & Ref \\
\hline & PDMS & Collagen 1 & $2.5 \mathrm{mg} / \mathrm{mL}$ & Primary & $\begin{array}{l}\text { HUVEC } \\
\text { SMC } \\
\text { Neutrophil }\end{array}$ & $\begin{array}{l}\text { Diffusional permeability } \\
\text { Leucocyte } \\
\text { transmigration } \\
\text { Blood perfusion }\end{array}$ & Atherosclerosis & $\begin{array}{c}\text { Formation of } \\
\text { pathophysiological } \\
\text { architectures for real-time } \\
\text { study of } \\
\text { cardiovascular disease }\end{array}$ & [146] \\
\hline & $\begin{array}{c}\text { PDMS } \\
\text { Polycarbonate }\end{array}$ & Fibrin & Scaffold & Primary & $\begin{array}{l}\text { HUVEC } \\
\text { lrVEC } \\
\text { hMSC }\end{array}$ & $\begin{array}{l}\text { Endothelial sprouting } \\
\text { Blood perfusion } \\
\text { Leukocyte adhesion } \\
\text { and migration } \\
\end{array}$ & $\begin{array}{l}\text { Vascularization of tissue } \\
\text { engineered scaffold }\end{array}$ & $\begin{array}{l}\text { Engineering of vasculature } \\
\text { in novel polycarbonate } \\
\text { scaffold with subsequent } \\
\text { surgical anastomosis }\end{array}$ & [147] \\
\hline \multirow{4}{*}{ Sacrificial molding } & PDMS & Collagen 1 & $3 \mathrm{mg} / \mathrm{mL}$ & Primary & $\begin{array}{c}\text { HUVEC } \\
\text { hBMSC/hLF/ } \\
\text { hASMCs/ } \\
\text { hKPC }\end{array}$ & $\begin{array}{l}\text { Diffusional permeability } \\
\text { Immunofluorescence } \\
\text { staining } \\
\text { Western blot } \\
\text { RT-qPCR }\end{array}$ & $\begin{array}{c}\text { Barrier function } \\
\text { variation with } \\
\text { inflammatory exposure }\end{array}$ & $\begin{array}{l}\text { Identification of key proteins } \\
\text { in regulating barrier function } \\
\text { in inflammation }\end{array}$ & [153] \\
\hline & PDMS & Collagen 1 & $2.5 \mathrm{mg} / \mathrm{mL}$ & Primary & hMVEC & $\begin{array}{c}\text { Diffusional permeability } \\
\text { Immunofluorescence } \\
\text { staining } \\
\text { RT-qPCR }\end{array}$ & $\begin{array}{c}\text { Influence of } \\
\text { hemodynamic shear } \\
\text { stress on endothelial } \\
\text { barrier function }\end{array}$ & $\begin{array}{l}\text { Identification of novel } \\
\text { mechanosensory complex }\end{array}$ & [231] \\
\hline & PDMS & Collagen 1 & $3 \mathrm{mg} / \mathrm{mL}$ & Primary & $\begin{array}{l}\text { HUVEC } \\
\text { hASMC }\end{array}$ & $\begin{array}{l}\text { Metabolic activity } \\
\text { Immunofluorescence } \\
\text { staining }\end{array}$ & $\begin{array}{l}\text { Defining physiological } \\
\text { vessel functionality or } \\
\text { pathologic remodeling }\end{array}$ & $\begin{array}{l}\text { Formation of stable arteriole } \\
\text { and artery-like structures }\end{array}$ & [151] \\
\hline & PDMS & Collagen 1 & $6.5 \mathrm{mg} / \mathrm{mL}$ & Primary & hMVEC & $\begin{array}{c}\text { LifeACT actin } \\
\text { remodeling } \\
\text { Diffusional permeability } \\
\text { Immunofluorescence } \\
\text { staining } \\
\text { Live/Dead staining }\end{array}$ & $\begin{array}{l}\text { Model for low-intensity } \\
\text { anti-vascular } \\
\text { ultrasound therapy }\end{array}$ & $\begin{array}{l}\text { Efficacy of low-intensity } \\
\text { ultrasound treatment of } \\
\text { tumors dependent on } \\
\text { fluid flow }\end{array}$ & [149] \\
\hline
\end{tabular}


Table 7. Cont.

\begin{tabular}{|c|c|c|c|c|c|c|c|c|c|}
\hline \multicolumn{6}{|c|}{ Device Specifics } & \multirow{2}{*}{$\begin{array}{l}\text { Assays } \\
\text { Assays }\end{array}$} & \multicolumn{3}{|c|}{ Additional Information } \\
\hline Method & Device Material & Hydrogel & Concentration & Cell Source & Cell Type(s) & & Application & Outcome & Ref \\
\hline & PDMS & Collagen 1 & $\begin{array}{c}3 \mathrm{mg} / \mathrm{mL}-6 \\
\mathrm{mg} / \mathrm{mL}\end{array}$ & Primary & $\begin{array}{l}\text { hLEC/HUVEC } \\
\text { nhMF/CAF }\end{array}$ & $\begin{array}{l}\text { Live/Dead staining } \\
\text { Cytokine quantification } \\
\text { RT-qPCR } \\
\text { Diffusional permeability } \\
\text { Immunofluorescence } \\
\text { staining }\end{array}$ & $\begin{array}{l}\text { Lymphatic vessel model } \\
\text { for understanding } \\
\text { physiologic and } \\
\text { pathology }\end{array}$ & $\begin{array}{l}\text { Organotypic lymphatic } \\
\text { function dependent on } \\
\text { cell-to-cell signaling }\end{array}$ & [154] \\
\hline \multirow{6}{*}{ Self-assembly } & PDMS & Collagen 1 & $3 \mathrm{mg} / \mathrm{mL}$ & Primary & HUVEC & $\begin{array}{l}\text { Sprouting analysis } \\
\text { Immunofluorescence } \\
\text { staining } \\
\text { Calpain and MMP } \\
\text { inhibition }\end{array}$ & $\begin{array}{l}\text { Platform to investigate } \\
\text { hemodynamic and } \\
\text { biochemical factors in } \\
\text { angiogenesis }\end{array}$ & $\begin{array}{l}\text { Angiogenesis dependent on } \\
\text { IF and VEGF concentration }\end{array}$ & [159] \\
\hline & PDMS & Fibrin & $\begin{array}{c}2.5 \mathrm{mg} / \mathrm{mL} \\
\text { fibrinogen } \\
1 \mathrm{U} / \mathrm{mL} \\
\text { Thrombin }\end{array}$ & Primary & $\begin{array}{c}\text { HUVEC } \\
\text { hLF }\end{array}$ & $\begin{array}{l}\text { Sprouting analysis } \\
\text { Immunofluorescence } \\
\text { staining }\end{array}$ & $\begin{array}{c}\text { Flow-mediated } \\
\text { endothelial dynamics } \\
\text { and phenotype changes }\end{array}$ & $\begin{array}{l}\text { Interstitial flow regulates } \\
\text { angiogenic sprouting and } \\
\text { endothelial cell phenotype }\end{array}$ & [158] \\
\hline & PDMS & Fibrin & $\begin{array}{c}2.5 \mathrm{mg} / \mathrm{mL} \\
\text { fibrinogen } \\
1 \mathrm{U} / \mathrm{mL} \\
\text { thrombin }\end{array}$ & Primary & $\begin{array}{l}\text { HUVEC } \\
\text { hASC }\end{array}$ & Network quantification & $\begin{array}{c}\text { Direct and indirect } \\
\text { perfusion of cell-seeded } \\
\text { hydrogels }\end{array}$ & $\begin{array}{l}\text { Direct cell-to-cell contact as } \\
\text { well as reciprocal signaling } \\
\text { molecules play a vital role } \\
\text { in vasculogenesis }\end{array}$ & [8] \\
\hline & PDMS & Fibrin & $\begin{array}{c}2.5 \mathrm{mg} / \mathrm{mL} \\
\text { fibrinogen } \\
1 \mathrm{U} / \mathrm{mL} \\
\text { thrombin }\end{array}$ & Primary & $\begin{array}{l}\text { hMVEC-dLyAd } \\
\text { NHLF }\end{array}$ & $\begin{array}{l}\text { Sprouting analysis } \\
\text { Immunofluorescence } \\
\text { staining } \\
\text { Cell viability }\end{array}$ & $\begin{array}{l}\text { Lymphangiogenesis in } \\
\text { tumor formation }\end{array}$ & $\begin{array}{l}\text { Interstitial flow augments } \\
\text { lymphatic endothelial } \\
\text { sprouting in synergy with } \\
\text { lymphangiogenic factors }\end{array}$ & [160] \\
\hline & PDMS & Fibrin & $\begin{array}{c}2.5 \mathrm{mg} / \mathrm{mL} \\
\text { fibrinogen } \\
1 \mathrm{U} / \mathrm{mL} \\
\text { thrombin }\end{array}$ & Primary & $\begin{array}{l}\text { HUVEC } \\
\text { NHLF }\end{array}$ & $\begin{array}{l}\text { Diffusional permeability } \\
\text { Glycocalyx staining } \\
\text { Colocalization analysis } \\
\text { Transcytosis mechanism }\end{array}$ & $\begin{array}{l}\text { Drug transport across } \\
\text { the vascular } \\
\text { endothelium and into } \\
\text { the target tissue }\end{array}$ & $\begin{array}{l}\text { On-chip model recapitulates } \\
\text { physiologic paracellular and } \\
\text { transcellular permeability }\end{array}$ & [161] \\
\hline & PDMS & Fibrin & $\begin{array}{c}5 \mathrm{mg} / \mathrm{mL} \\
\text { fibrinogen } \\
1 \mathrm{U} / \mathrm{mL} \\
\text { thrombin }\end{array}$ & Primary & $\begin{array}{l}\text { HUVEC } \\
\text { NHLF }\end{array}$ & $\begin{array}{c}\text { Immunofluorescence } \\
\text { staining } \\
\text { Cell viability } \\
\text { Network quantification } \\
\text { Diffusional permeability } \\
\text { Colocalization analysis }\end{array}$ & $\begin{array}{l}\text { Vascular remodeling in } \\
\text { Idiopathic pulmonary } \\
\text { fibrosis }\end{array}$ & $\begin{array}{l}\text { Anti-vasculogenic drug acts } \\
\text { on endothelial network } \\
\text { formation and } \\
\text { endothelial-perivascular } \\
\text { interactions }\end{array}$ & [162] \\
\hline
\end{tabular}


Table 7. Cont

\begin{tabular}{|c|c|c|c|c|c|c|c|c|c|}
\hline \multicolumn{6}{|c|}{ Device Specifics } & \multirow{2}{*}{$\begin{array}{l}\text { Assays } \\
\text { Assays }\end{array}$} & \multicolumn{3}{|c|}{ Additional Information } \\
\hline Method & Device Material & Hydrogel & Concentration & Cell Source & Cell Type(s) & & Application & Outcome & Ref \\
\hline & PDMS & Fibrin & $\begin{array}{l}2.5 \mathrm{mg} / \mathrm{mL} \\
\text { fibrinogen } \\
0.5 \mathrm{U} / \mathrm{mL} \\
\text { thrombin }\end{array}$ & Primary & $\begin{array}{l}\text { HUVEC } \\
\text { NHLF } \\
\text { hPC-PL }\end{array}$ & $\begin{array}{c}\text { Blood vessel contraction } \\
\text { Oxidative stress } \\
\text { Immunofluorescence } \\
\text { staining } \\
\text { Diffusional permeability }\end{array}$ & $\begin{array}{l}\text { Nanoparticle toxicity on } \\
\text { endothelial barrier }\end{array}$ & $\begin{array}{l}\text { Nanoparticle exposure leads } \\
\text { to microvessel contraction } \\
\text { and nanoparticles are } \\
\text { transported via } \\
\text { caveolae-mediated } \\
\text { transcytosis }\end{array}$ & [163] \\
\hline & PDMS & Fibrin & $\begin{array}{l}1 \mathrm{U} / \mathrm{mL} \\
\text { thrombin }\end{array}$ & Primary & $\begin{array}{l}\text { HUVEC } \\
\text { NHLF }\end{array}$ & $\begin{array}{l}\text { Immunofluorescence } \\
\text { staining } \\
\text { Diffusional permeability }\end{array}$ & $\begin{array}{l}\text { Pathogenesis of inhaled } \\
\text { atmospheric } \\
\text { nanoparticles }\end{array}$ & $\begin{array}{l}\text { Atmospheric nanoparticle } \\
\text { inhalation leads to a loss of } \\
\text { tight junctions and increased } \\
\text { vascular permeability }\end{array}$ & [164] \\
\hline
\end{tabular}

Table 8. Blood-brain-barrier-on-a-chip applications.

\begin{tabular}{|c|c|c|c|c|c|c|c|c|c|c|c|}
\hline \multicolumn{5}{|c|}{ Device Specifics } & \multicolumn{2}{|c|}{ Assays } & \multicolumn{5}{|c|}{ Additional Information } \\
\hline Method & $\begin{array}{c}\text { Device } \\
\text { Material }\end{array}$ & $\begin{array}{l}\text { Culture } \\
\text { Condition }\end{array}$ & Cell Type & $\begin{array}{l}\text { Immuno- } \\
\text { Staining }\end{array}$ & $\begin{array}{c}\text { Fluorescent } \\
\text { Tracker } \\
\text { [kDa] }\end{array}$ & TEER Values & $\begin{array}{c}\text { Other } \\
\text { Features }\end{array}$ & $\begin{array}{c}\text { Shear Stress } \\
{[\mathrm{Pa}]}\end{array}$ & $\begin{array}{l}\text { External } \\
\text { Stimuli }\end{array}$ & Outcome & Ref. \\
\hline $\begin{array}{l}\text { Sandwich } \\
\text { Design }\end{array}$ & $\begin{array}{l}\text { PDMS } \\
\text { 2D }\end{array}$ & $\begin{array}{l}7 \text { days } \\
\text { ECM: Col IV, } \\
\text { fibronectin, } \\
\text { Col I }\end{array}$ & $\begin{array}{c}\text { b.End3 (mouse) } \\
\text { C8D1A } \\
\text { (mouse) }\end{array}$ & Claudin-5 & Dextran: 70 & - & - & 0.5 & - & $\begin{array}{l}\text { Optically transparent } \\
\text { PTFE membrane might } \\
\text { be a suitable alternative }\end{array}$ & [169] \\
\hline $\begin{array}{l}\text { Sandwich } \\
\text { Design }\end{array}$ & $\begin{array}{l}\text { PDMS } \\
\text { 2D }\end{array}$ & $\begin{array}{l}6 \text { days } \\
\text { ECM: } \\
\text { Col I/IV }\end{array}$ & $\begin{array}{c}\text { hCMEC /D3 or } \\
\text { primary rat } \\
\text { endothelial cells } \\
\text { primary pericytes } \\
\text { (rat) } \\
\text { primary astrocytes } \\
\text { (rat) }\end{array}$ & $\begin{array}{c}\mathrm{ZO}-1 \\
\beta \text {-catenin }\end{array}$ & $\begin{array}{c}\text { Dextran: } 4.4 \\
\text { Albumin: } 67 \\
\text { Sodium } \\
\text { fluorescin }\end{array}$ & $175 \Omega \mathrm{cm}^{2}$ & $\begin{array}{c}\text { Direct contact } \\
\text { between } \\
\text { endothelial } \\
\text { cells and } \\
\text { pericytes }\end{array}$ & $1.5 \times 10^{-2}$ & - & $\begin{array}{l}\text { Primary cells exhibited } \\
\text { better BBB properties } \\
\text { than hCMEC/D3 cells. }\end{array}$ & [212] \\
\hline
\end{tabular}


Table 8. Cont.

\begin{tabular}{|c|c|c|c|c|c|c|c|c|c|c|c|}
\hline \multicolumn{5}{|c|}{ Device Specifics } & \multicolumn{3}{|c|}{ Assays } & \multicolumn{3}{|c|}{ Additional Information } & \multirow[b]{2}{*}{ Ref. } \\
\hline Method & $\begin{array}{c}\text { Device } \\
\text { Material }\end{array}$ & $\begin{array}{l}\text { Culture } \\
\text { Condition }\end{array}$ & Cell Type & $\begin{array}{l}\text { Immuno- } \\
\text { Staining }\end{array}$ & $\begin{array}{c}\text { Fluorescent } \\
\text { Tracker } \\
\text { [kDa] }\end{array}$ & TEER Values & $\begin{array}{l}\text { Other } \\
\text { Features }\end{array}$ & $\begin{array}{c}\text { Shear Stress } \\
{[\mathrm{Pa}]}\end{array}$ & $\begin{array}{l}\text { External } \\
\text { Stimuli }\end{array}$ & Outcome & \\
\hline $\begin{array}{l}\text { Sandwich } \\
\text { Design }\end{array}$ & $\begin{array}{l}\text { Objet } \\
\text { VeroClear } \\
\text { photo- } \\
\text { polymer } \\
- \\
\text { Parylene-C } \\
\text { coating } \\
\text { 2D }\end{array}$ & $\begin{array}{l}10 \text { days } \\
\text { ECM: } \\
\text { Col I } \\
\text { Fibronectin }\end{array}$ & $\begin{array}{c}\text { iPSC derived } \\
\text { BMEC (human) } \\
\text { primary astrocytes } \\
\text { (rat) }\end{array}$ & $\begin{array}{c}\text { ZO-1 } \\
\text { Claudin-5 }\end{array}$ & $\begin{array}{c}\text { Dextran: } 4,20 \\
\quad 70\end{array}$ & $\begin{array}{l}2000 \\
\Omega \mathrm{cm}^{2}\end{array}$ & $\begin{array}{l}\text { Caffeine } \\
\text { Cimetidine } \\
\text { Doxorubicin }\end{array}$ & $1.4-25 \times 10^{-3}$ & - & $\begin{array}{l}\text { First time the application } \\
\text { of iPSCs-derived BMEC } \\
\text { in co-culture with } \\
\text { astrocyte (enhanced BBB } \\
\text { integrity) } \\
\text { Doxorubicin disrupts } \\
\text { BBB integrity after } \\
\text { 24-h treatment }\end{array}$ & [233] \\
\hline $\begin{array}{l}\text { Sandwich } \\
\text { Design }\end{array}$ & $\begin{array}{c}\text { PDMS and } \\
\text { polycarbonate } \\
2 \mathrm{D}\end{array}$ & $\begin{array}{l}4 \text { days } \\
\text { ECM: } \\
\text { Fibronectin vs. } \\
\text { Matrigel }\end{array}$ & $\begin{array}{c}\text { Primary BMVEC } \\
\text { (mouse) } \\
\text { Astrocytes } \\
\text { (mouse) }\end{array}$ & $\begin{array}{l}\text { ZO-1 } \\
\text { GFAP }\end{array}$ & $\begin{array}{c}\text { Dextran: } 3,7 \\
10\end{array}$ & $3500 \Omega$ & - & $0.1-3$ & $\begin{array}{l}\text { Histamine } \\
\text { disruption }\end{array}$ & $\begin{array}{l}\text { Multi-channel model } \\
\text { with an integrated } \\
\text { electrical impedance } \\
\text { sensor array } \\
\text { Matrigel provides better } \\
\text { barrier integrity } \\
\text { than fibronectin }\end{array}$ & [234] \\
\hline $\begin{array}{l}\text { Sandwich } \\
\text { Design }\end{array}$ & $\begin{array}{l}\text { PDMS } \\
\text { 2D }\end{array}$ & $\begin{array}{l}6 \text { days } \\
\text { ECM: } \\
\text { Fibronectin } \\
\text { and Col IV }\end{array}$ & $\begin{array}{l}\text { bEnd.3 } \\
\text { (mouse) }\end{array}$ & Claudin-5 & $\begin{array}{c}\text { Dextran: } 4,20 \\
500\end{array}$ & $172 \Omega \mathrm{cm}^{2}$ & - & $0.1-0.6$ & - & $\begin{array}{l}\text { Angiopep-2 peptide } \\
\text { modification facilitates } \\
\text { nanoparticle transport } \\
\text { across the BBB }\end{array}$ & [235] \\
\hline $\begin{array}{l}\text { Parallel } \\
\text { design }\end{array}$ & $\begin{array}{l}\text { PDMS } \\
\text { 3D }\end{array}$ & $\begin{array}{l}5 \text { days } \\
\text { ECM: } \\
\text { fibronectin }\end{array}$ & $\begin{array}{c}\text { RBE4 (rat) } \\
\text { astrocytes (rat) }\end{array}$ & $\begin{array}{l}\text { ZO-1 } \\
\text { GFAP }\end{array}$ & Dextran: 40 & $250 \Omega \mathrm{cm}^{2}$ & - & $3.8 \times 10^{-4}$ & - & $\begin{array}{c}\text { Co-culture with } \\
\text { astrocytes increases } \\
\text { barrier integrity } \\
\text { Cell/cell interactions are } \\
\text { observed } \\
\text { Endothelial cells are } \\
\text { sensitive to astrocyte } \\
\text { conditioned medium }\end{array}$ & [174] \\
\hline
\end{tabular}


Table 8. Cont

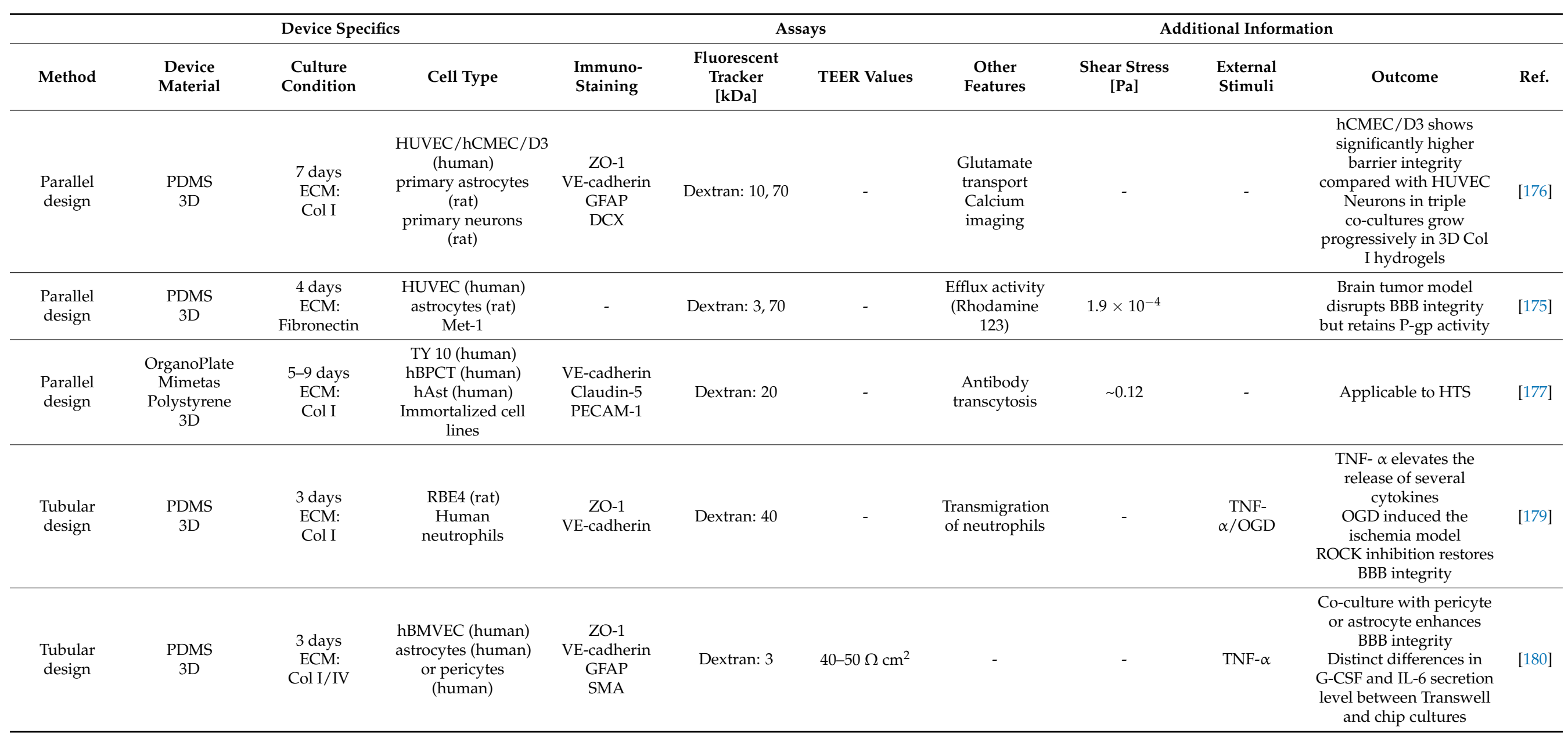


Table 8. Cont.

\begin{tabular}{|c|c|c|c|c|c|c|c|c|c|c|c|}
\hline \multicolumn{5}{|c|}{ Device Specifics } & \multicolumn{3}{|c|}{ Assays } & \multicolumn{3}{|c|}{ Additional Information } & \multirow[b]{2}{*}{ Ref. } \\
\hline Method & $\begin{array}{l}\text { Device } \\
\text { Material }\end{array}$ & $\begin{array}{l}\text { Culture } \\
\text { Condition }\end{array}$ & Cell Type & $\begin{array}{l}\text { Immuno- } \\
\text { staining }\end{array}$ & $\begin{array}{c}\text { Fluorescent } \\
\text { Tracker } \\
\text { [kDa] }\end{array}$ & TEER values & $\begin{array}{l}\text { Other } \\
\text { Features }\end{array}$ & $\begin{array}{c}\text { Shear Stress } \\
\quad[\mathrm{Pa}]\end{array}$ & $\begin{array}{l}\text { External } \\
\text { Stimuli }\end{array}$ & Outcome & \\
\hline $\begin{array}{l}\text { Tubular } \\
\text { Design }\end{array}$ & $\begin{array}{l}\text { PDMS } \\
\text { 3D }\end{array}$ & $\begin{array}{l}4 \text { days } \\
\text { ECM: } \\
\text { Col I } \\
\text { Matrigel } \\
\text { HA }\end{array}$ & $\begin{array}{c}\text { hCMEC/D3 } \\
\text { (human) } \\
\text { astrocytes (human) }\end{array}$ & $\begin{array}{l}\text { ZO-1 } \\
\text { GFAP }\end{array}$ & Dextran: 4 & $\begin{array}{c}1000-1200 \\
\Omega \mathrm{cm}^{2}\end{array}$ & TEM & 0.07 & TNF- $\alpha$ & $\begin{array}{l}\text { Shear stress significantly } \\
\text { improves BBB integrity } \\
\text { Pulsatile flow drives } \\
\text { retrograde transport } \\
\text { along the basement } \\
\text { membrane }\end{array}$ & [237] \\
\hline $\begin{array}{l}\text { Tubular } \\
\text { Design }\end{array}$ & $\begin{array}{l}\text { IP-DiLL } \\
\text {-SU8 } \\
\text { 3D }\end{array}$ & $\begin{array}{l}3 \text { days } \\
\text { ECM: - }\end{array}$ & $\begin{array}{c}\text { b.End.3 } \\
\text { (mouse) } \\
\text { U-87 (human) }\end{array}$ & $\mathrm{ZO}-1$ & Dextran: 10 & $71 \Omega \mathrm{cm}^{2}$ & - & - & - & $\begin{array}{l}\text { Two-photon lithography } \\
\text { fabricated 3D tubular } \\
\text { structures with } 1: 1 \text { scale } \\
\text { of capillaries }\end{array}$ & [238] \\
\hline $\begin{array}{l}\text { Vasculogenesis } \\
\text { Design }\end{array}$ & $\begin{array}{l}\text { PDMS } \\
\text { 3D }\end{array}$ & $\begin{array}{l}3 \text { days } \\
\text { ECM: } \\
\text { Fibrinogen }\end{array}$ & $\begin{array}{c}\text { iPSC-EC } \\
\text { (human) } \\
\text { brain pericytes } \\
\text { (human) } \\
\text { brain astrocytes } \\
\text { (human) }\end{array}$ & $\begin{array}{l}\text { CD31 } \\
\text { ZO-1 } \\
\text { GFAP }\end{array}$ & Dextran: 20, 70 & - & - & - & - & $\begin{array}{l}\text { The best combination of } \\
\text { cells for co-culture is } \\
\text { identified }\end{array}$ & [182] \\
\hline
\end{tabular}


Table 9. Central nervous system-on-a-chip applications.

\begin{tabular}{|c|c|c|c|c|c|c|c|c|}
\hline \multicolumn{4}{|c|}{ Device Specifics } & \multirow{2}{*}{$\begin{array}{l}\text { Assays } \\
\text { Assays }\end{array}$} & \multicolumn{4}{|c|}{ Additional Information } \\
\hline Application & $2 \mathrm{D} / 3 \mathrm{D}$ & Device Material & Cell Type & & Flow & $\begin{array}{l}\text { External } \\
\text { Stimuli }\end{array}$ & Outcome & Ref. \\
\hline $\begin{array}{l}\text { Neuronal } \\
\text { development-3D } \\
\text { Organoid formation } \\
\text { on chip }\end{array}$ & $\begin{array}{c}\text { 3D } \\
\text { ECM: } \\
\text { Matrigel }\end{array}$ & PDMS & iPSCs & $\begin{array}{c}\text { Immunocytochemistry } \\
\text { PCR } \\
\text { TUNEL assay }\end{array}$ & $25 \mu \mathrm{L} \mathrm{h}^{-1}$ & - & $\begin{array}{l}\text { Organoids display feature specific } \\
\text { identities such as neuronal differentiation, } \\
\text { brain regionalization, and cortical } \\
\text { spatial organization } \\
\text { Improved cortical development } \\
\text { compared to static culture conditions }\end{array}$ & [189] \\
\hline $\begin{array}{c}\text { Neuronal } \\
\text { development-Prenatal } \\
\text { nicotine exposure }\end{array}$ & $\begin{array}{c}\text { 3D } \\
\text { ECM: } \\
\text { Matrigel }\end{array}$ & PDMS & iPSCs & $\begin{array}{c}\text { Immunocytochemistry } \\
\text { PCR } \\
\text { TUNEL assay } \\
\text { Neurite outgrowth assay } \\
\text { (TUJ1) }\end{array}$ & $25 \mu \mathrm{Lh}^{-1}$ & Nicotine & $\begin{array}{l}\text { Nicotine exposure led to premature } \\
\text { neuronal differentiation, disrupted brain } \\
\text { regional organization, abnormal cortical } \\
\text { development, neuronal outgrowth, and } \\
\text { increased cell apoptosis. }\end{array}$ & [190] \\
\hline $\begin{array}{c}\text { Neuronal } \\
\text { development-Effect of } \\
\text { endothelial cells on } \\
\text { neuronal development }\end{array}$ & $2 \mathrm{D}$ & PDMS & $\begin{array}{c}\text { iPSC derived } \\
\text { spinal motor } \\
\text { neurons } \\
\text { iPSC derived BMECs }\end{array}$ & $\begin{array}{c}\text { Immunocytochemistry } \\
\text { Transcriptomics } \\
\text { Live Calcium Transient } \\
\text { Imaging Analysis }\end{array}$ & - & - & $\begin{array}{l}\text { Vascular-neural interaction and specific } \\
\text { gene activation enhances neuronal } \\
\text { function and enables } \\
\text { in vivo-like signatures }\end{array}$ & [186] \\
\hline $\begin{array}{c}\text { Neuronal } \\
\text { development-High } \\
\text { throughput generation of } \\
\text { human brain organoids }\end{array}$ & $\begin{array}{c}\text { 3D } \\
\text { ECM: } \\
\text { Matrigel }\end{array}$ & PDMS & - & $\begin{array}{c}\text { Immunocytochemistry } \\
\text { PCR }\end{array}$ & - & - & $\begin{array}{l}\text { Controlled formation of human brain } \\
\text { organoids on chip }\end{array}$ & [192] \\
\hline $\begin{array}{l}\text { Neuronal } \\
\text { development-Neuronal } \\
\text { differentiation and } \\
\text { chemotaxis }\end{array}$ & $3 \mathrm{D}$ & PDMS & $\begin{array}{c}\text { hNT-2 } \\
\text { hNPCs } \\
\text { Immortalized } \\
\text { hBMECs }\end{array}$ & $\begin{array}{l}\text { Immunocytochemistry } \\
\text { Chemotaxis assay }\end{array}$ & - & $\begin{array}{l}\text { CXCL12 } \\
\text { SLIT2-N }\end{array}$ & $\begin{array}{l}\text { hNPCs respond to shallow gradients of } \\
\text { CXCL12 only in the presence of a } \\
\text { micro-environment mimicking the brain } \\
\text { parenchyma milieu } \\
\text { hNPCs are more polarized in the presence } \\
\text { of a neuronal-glial cell population, which } \\
\text { leads to more directed movement }\end{array}$ & [239] \\
\hline $\begin{array}{c}\text { Neuronal } \\
\text { development-Physics of } \\
\text { brain folding }\end{array}$ & $\begin{array}{c}\text { 3D } \\
\text { ECM: } \\
\text { Matrigel }\end{array}$ & PDMS & hESC & $\begin{array}{c}\text { Immunocytochemistry } \\
\text { RNA sequencing } \\
\text { AFM }\end{array}$ & - & Blebbistatin & $\begin{array}{l}\text { On-chip organoid approach successfully } \\
\text { mimics the early developing cortex } \\
\text { Lissencephalic organoids display reduced } \\
\text { convolutions, modified scaling, and a } \\
\text { reduced elastic modulus }\end{array}$ & [191] \\
\hline
\end{tabular}


Table 9. Cont.

\begin{tabular}{|c|c|c|c|c|c|c|c|c|}
\hline \multicolumn{4}{|c|}{ Device Specifics } & \multirow{2}{*}{$\begin{array}{l}\text { Assays } \\
\text { Assays }\end{array}$} & \multicolumn{4}{|c|}{ Additional Information } \\
\hline Application & 2D/3D & Device Material & Cell Type & & Flow & $\begin{array}{l}\text { External } \\
\text { Stimuli }\end{array}$ & Outcome & Ref. \\
\hline $\begin{array}{l}\text { Neuronal networks } \\
- \\
\begin{array}{c}\text { Multi-regional brain on } \\
\text { chip }\end{array}\end{array}$ & $2 \mathrm{D}$ & PDMS & $\begin{array}{l}\text { Hippocampal } \\
\text { neurons (rat) } \\
\text { Amygdala neurons } \\
\text { (rat) } \\
\text { Prefrontal cortex } \\
\text { neurons } \\
\text { (rat) } \\
\end{array}$ & $\begin{array}{l}\text { Immunocytochemistry } \\
\text { Proteomics } \\
\text { MS } \\
\text { Oxygen Measurement } \\
\text { MEA }\end{array}$ & & $\begin{array}{l}\text { Phencyclidine } \\
\text { hydro } \\
\text { chloride }\end{array}$ & $\begin{array}{l}\text { Distinct differences in metabolism in } \\
\text { different brain regions in vitro } \\
\text { Changed electrical activity profile upon } \\
\text { connecting individual regions } \\
\text { PCP treatment alters electrical activity in } \\
\text { a region-dependent manner }\end{array}$ & [184] \\
\hline $\begin{array}{c}\text { Neuronal networks } \\
- \\
\text { 3D neural circuit }\end{array}$ & $\begin{array}{c}\text { 3D } \\
\text { ECM: } \\
\text { Matrigel }\end{array}$ & PDMS & $\begin{array}{l}\text { Cortical neurons } \\
\quad \text { (rat) }\end{array}$ & $\begin{array}{l}\text { Immunocytochemistry } \\
\text { Calcium imaging }\end{array}$ & - & - & $\begin{array}{l}\text { Axons formed in vivo like neural bundles } \\
\text { with fasciculation and defasciculation. } \\
\text { Aligned neural circuits with visualizable } \\
\text { synapses. }\end{array}$ & [185] \\
\hline $\begin{array}{c}\text { Neuronal networks } \\
- \\
\text { Neuronal network for } \\
\text { active compound testing }\end{array}$ & $2 \mathrm{D}$ & PDMS & $\begin{array}{l}\text { Hippocampal } \\
\text { neurons (rat) }\end{array}$ & $\begin{array}{c}\text { Immunocytochemistry } \\
\text { Viability assay } \\
\text { Calcium imaging }\end{array}$ & $0.4-10 \mu \mathrm{L} \mathrm{min}-1$ & Glutamate & $\begin{array}{l}\text { Integration of microfluidic perfusion with } \\
\mathrm{Ca}^{2+} \text { imaging techniques }\end{array}$ & [187] \\
\hline $\begin{array}{c}\begin{array}{c}\text { Neuro-degenerative } \\
\text { diseases } \\
-\end{array} \\
\text { Alzheimer's disease } \\
\end{array}$ & $\begin{array}{c}\text { 3D } \\
\text { neurospheroid }\end{array}$ & PDMS & $\begin{array}{l}\text { Primary cortical } \\
\text { neurons (rat) }\end{array}$ & $\begin{array}{c}\text { Immunocytochemistry } \\
\text { CCK-8 } \\
\text { SEM }\end{array}$ & $\begin{array}{l}\text { Interstitial } \\
\text { fluid flow }\end{array}$ & Amyloid $\beta$ & $\begin{array}{c}\text { Interstitial fluid flow positively affects the } \\
\text { maturation of neurospheroids } \\
\text { Amyloid } \beta \text { treatment induced neural } \\
\text { network induction }\end{array}$ & [198] \\
\hline $\begin{array}{l}\text { Neuro-degenerative } \\
\text { diseases-ALS }\end{array}$ & $\begin{array}{l}\text { 3D } \\
\text { ECM: Col I }\end{array}$ & PDMS & $\begin{array}{l}\text { iPSCs derived motor } \\
\text { neurons } \\
\text { iPSCs derived } \\
\text { skeletal muscle cells } \\
\text { iPSCs derived } \\
\text { endothelial cells }\end{array}$ & $\begin{array}{c}\text { Immunocytochemistry } \\
\text { PCR } \\
\mathrm{Ca}^{2+} \text { oscillation imaging } \\
\text { SNP genotyping } \\
\text { Whole exome sequencing } \\
\text { Western blot }\end{array}$ & - & $\begin{array}{l}\text { Rapamycin } \\
\text { Bosutinib }\end{array}$ & $\begin{array}{l}\text { Muscle contraction could be induced by } \\
\text { MN activity once NMJ is formed } \\
\text { ALS motor unit displayed higher levels of } \\
\text { apoptosis and reduced muscle } \\
\text { contraction force } \\
\text { Combinatorial treatments improved } \\
\text { neuronal survival and an increased } \\
\text { muscle contraction force }\end{array}$ & [199] \\
\hline
\end{tabular}


Table 9. Cont.

\begin{tabular}{|c|c|c|c|c|c|c|c|c|}
\hline \multicolumn{4}{|c|}{ Device Specifics } & \multirow{2}{*}{$\begin{array}{l}\text { Assays } \\
\text { Assays }\end{array}$} & \multicolumn{4}{|c|}{ Additional Information } \\
\hline Application & $2 \mathrm{D} / 3 \mathrm{D}$ & Device Material & Cell Type & & Flow & $\begin{array}{l}\text { External } \\
\text { Stimuli }\end{array}$ & Outcome & Ref. \\
\hline $\begin{array}{l}\text { Brain cancer chip for } \\
\text { HTS }\end{array}$ & $3 \mathrm{D}$ & PEGDa & $\begin{array}{c}\text { U87 } \\
\text { Primary } \\
\text { glioblastoma tumors }\end{array}$ & $\begin{array}{l}\text { Immunocytochemistry } \\
\text { Diffusion test } \\
\text { Viability }\end{array}$ & - & $\begin{array}{l}\text { Pitavastatin } \\
\text { Irinotecan } \\
\text { Temozo-lomide } \\
\text { Bevacizumab }\end{array}$ & $\begin{array}{l}\text { HTS platform for spheroid formation } \\
\text { and drug screening } \\
\text { Combinatorial treatment with TMZ } \\
\text { and BEV were more effective on } \\
\text { glioblastoma spheroids }\end{array}$ & {$[195,241]$} \\
\hline Cancer migration study & - & PDMS & $\begin{array}{l}\text { Hippocampal } \\
\text { neurons (rat) } \\
\text { Cortical neurons (rat) } \\
\text { DRG neurons (rat) } \\
\text { PC-3 (human) } \\
\text { Panc-1 (human) } \\
\text { MCF-1 (human) }\end{array}$ & Immunocytochemistry & - & $\begin{array}{l}\beta \text {-blockers } \\
\text { muscarinic } \\
\text { antagonists } \\
\text { Neuron injury } \\
\text { (6-hydroxy- } \\
\text { dopamine) }\end{array}$ & $\begin{array}{l}\text { Neurites guide the directional } \\
\text { movement of cancer cells. } \\
\text { Cancer cells with high levels of } \\
\text { perineural invasion display greater } \\
\text { migration along neurites. } \\
\text { Neuron injury reduces migration of } \\
\text { cancer cells. } \\
\text { Muscarinic antagonists } \\
\text { reduced migration. }\end{array}$ & [236] \\
\hline Effects of GDNF on NMJ & $2 \mathrm{D}$ & PDMS & $\begin{array}{l}\text { Skeletal myocytes } \\
\text { (murine) } \\
\text { Neurons } \\
\text { (murine) }\end{array}$ & $\begin{array}{l}\text { Immunocytochemistry } \\
\text { Calcium live imaging }\end{array}$ & - & $\begin{array}{c}\text { GDNF } \\
\text { Oxidative stress } \\
\text { BTX }\end{array}$ & $\begin{array}{l}\text { Spatially distinct effects of GDNF } \\
\text { on MN. }\end{array}$ & [242] \\
\hline $\begin{array}{c}\text { Combinatorial } \\
\text { systems } \\
- \\
\text { Co-culture of liver and } \\
\text { neurospheres }\end{array}$ & $3 \mathrm{D}$ & PDMS & $\begin{array}{c}\text { HepaRG } \\
\text { (human) } \\
\text { Hepatic stellate cells } \\
\text { (human) } \\
\text { hNT-2 }\end{array}$ & $\begin{array}{c}\text { Immunocytochemistry } \\
\text { qPCR } \\
\text { LDH activity } \\
\text { Metabolic activity } \\
\text { TUNEL assay }\end{array}$ & NA & 2,5-hexanedione & $\begin{array}{l}\text { Successful co-culture of } \\
\text { neuro-spheres and liver spheroids for } \\
\quad 14 \text { days. } \\
\text { Co-culture was more susceptible to } \\
2,5 \text {-hexanedione } \\
\text { treatment compared to monocultures. }\end{array}$ & [194] \\
\hline
\end{tabular}


Author Contributions: M.R., B.E.M.B., C.E., S.R.A.K., and S.S. contributed equally as shared first authors. Conceptualization, M.R. Literature research, M.R., B.E.M.B., C.E., S.R.A.K., S.S., and G.H. Writing-original draft preparation, M.R., B.E.M.B., C.E., S.R.A.K., S.S., and P.E. Writing-review and editing, M.R., B.E.M.B., C.E., S.R.A.K., S.S., and P.E. Supervision, M.R. and P.E. All authors have read and agreed to the published version of the manuscript.

Funding: The APC was funded by TU Wien University Library for financial support through its Open Access Funding Program.

Data Availability Statement: Data is available under reasonable email request.

Acknowledgments: The authors acknowledge that the Open Access Funding by TU Wien.

Conflicts of Interest: The authors declare no conflict of interest.

\section{References}

1. Whitesides, G.M. The origins and the future of microfluidics. Nature 2006, 442, 368-373. [CrossRef]

2. Cann, O. These are the top 10 emerging technologies of 2016. World Econ. Forum. 2016. Available online: https://www.weforum. org/agenda/2016/06/top-10-emerging-technologies-2016/ (accessed on 31 March 2021).

3. Ertl, P.; Sticker, D.; Charwat, V.; Kasper, C.; Lepperdinger, G. Lab-on-a-chip technologies for stem cell analysis. Trends Biotechnol. 2014, 32, 245-253. [CrossRef] [PubMed]

4. $\quad$ Benam, K.H.; Novak, R.; Nawroth, J.; Hirano-Kobayashi, M.; Ferrante, T.C.; Choe, Y.; Prantil-Baun, R.; Weaver, J.C.; Bahinski, A.; Parker, K.K.; et al. Matched-Comparative Modeling of Normal and Diseased Human Airway Responses Using a Microengineered Breathing Lung Chip. Cell Syst. 2016, 3, 456-466.e4. [CrossRef]

5. Ergir, E.; Bachmann, B.; Redl, H.; Forte, G.; Ertl, P. Small Force, Big Impact: Next Generation Organ-on-a-Chip Systems Incorporating Biomechanical Cues. Front. Physiol. 2018, 9, 1417. [CrossRef]

6. Zirath, H.; Rothbauer, M.; Spitz, S.; Bachmann, B.; Jordan, C.; Müller, B.; Ehgartner, J.; Priglinger, E.; Mühleder, S.; Redl, H.; et al. Every Breath You Take: Non-invasive Real-Time Oxygen Biosensing in Two- and Three-Dimensional Microfluidic Cell Models. Front. Physiol. 2018, 9, 815. [CrossRef]

7. Eilenberger, C.; Rothbauer, M.; Ehmoser, E.-K.; Ertl, P.; Küpcü, S. Effect of Spheroidal Age on Sorafenib Diffusivity and Toxicity in a 3D HepG2 Spheroid Model. Sci. Rep. 2019, 9, 4863. [CrossRef] [PubMed]

8. Bachmann, B.; Spitz, S.; Rothbauer, M.; Jordan, C.; Purtscher, M.; Zirath, H.; Schuller, P.; Eilenberger, C.; Ali, S.F.; Mühleder, S.; et al. Engineering of three-dimensional pre-vascular networks within fibrin hydrogel constructs by microfluidic control over reciprocal cell signaling. Biomicrofluidics 2018, 12. [CrossRef]

9. Sticker, D.; Rothbauer, M.; Ehgartner, J.; Steininger, C.; Liske, O.; Liska, R.; Neuhaus, W.; Mayr, T.; Haraldsson, T.; Kutter, J.P.; et al. Oxygen Management at the Microscale: A Functional Biochip Material with Long-Lasting and Tunable Oxygen Scavenging Properties for Cell Culture Applications. ACS Appl. Mater. Interfaces 2019, 11, 9730-9739. [CrossRef] [PubMed]

10. Li, A.P.; Bode, C.; Sakai, Y. A novel in vitro system, the integrated discrete multiple organ cell culture (IdMOC) system, for the evaluation of human drug toxicity: Comparative cytotoxicity of tamoxifen towards normal human cells from five major organs and MCF-7 adenocarcinoma breast cancer cells. Chem. Biol. Interact. 2004, 150, 129-136. [CrossRef] [PubMed]

11. Sin, A.; Chin, K.C.; Jamil, M.F.; Kostov, Y.; Rao, G.; Shuler, M.L. The Design and Fabrication of Three-Chamber Microscale Cell Culture Analog Devices with Integrated Dissolved Oxygen Sensors. Biotechnol. Prog. 2004, 20, 338-345. [CrossRef] [PubMed]

12. Hosokawa, K.; Maeda, R. Pneumatically-actuated three-way microvalve fabricated with polydimethylsiloxane using the membrane transfer technique. J. Micromech. Microeng. 2000, 10, 415-420. [CrossRef]

13. Kim, J.; Kang, M.; Jensen, E.C.; Mathies, R.A. Lifting gate polydimethylsiloxane microvalves and pumps for microfluidic control. Anal. Chem. 2012, 84, 2067-2071. [CrossRef] [PubMed]

14. Unger, M.A.; Chou, H.P.; Thorsen, T.; Scherer, A.; Quake, S.R. Monolithic microfabricated valves and pumps by multilayer soft lithography. Science 2000, 288, 113-116. [CrossRef]

15. Rothbauer, M.; Zirath, H.; Ertl, P. Recent advances in microfluidic technologies for cell-to-cell interaction studies. Lab Chip 2018, 18, 249-270. [CrossRef] [PubMed]

16. Rothbauer, M.; Rosser, J.M.; Zirath, H.; Ertl, P. Tomorrow today: Organ-on-a-chip advances towards clinically relevant pharmaceutical and medical in vitro models. Curr. Opin. Biotechnol. 2019, 55, 81-86. [CrossRef]

17. Shafiee, A.; Ghadiri, E.; Kassis, J.; Pourhabibi Zarandi, N.; Atala, A. Biosensing Technologies for Medical Applications, Manufacturing, and Regenerative Medicine. Curr. Stem Cell Rep. 2018, 4, 105-115. [CrossRef]

18. Kratz, S.R.A.; Höll, G.; Schuller, P.; Ertl, P.; Rothbauer, M. Latest trends in biosensing for microphysiological organs-on-a-chip and body-on-a-chip systems. Biosensors 2019, 9, 110. [CrossRef]

19. Cho, S.; Yoon, J.Y. Organ-on-a-chip for assessing environmental toxicants. Curr. Opin. Biotechnol. 2017, 45, 34-42. [CrossRef]

20. Günther, A.; Yasotharan, S.; Vagaon, A.; Lochovsky, C.; Pinto, S.; Yang, J.; Lau, C.; Voigtlaender-Bolz, J.; Bolz, S.S. A microfluidic platform for probing small artery structure and function. Lab Chip 2010, 10, 2341-2349. [CrossRef]

21. Blundell, C.; Tess, E.R.; Schanzer, A.S.; Coutifaris, C.; Su, E.J.; Parry, S.; Huh, D. A microphysiological model of the human placental barrier. Lab Chip 2016, 16, 3065-3073. [CrossRef] 
22. Mandt, D.; Gruber, P.; Markovic, M.; Tromayer, M.; Rothbauer, M.; Adam Kratz, S.R.; Ali, S.F.; van Hoorick, J.; Holnthoner, W.; Mühleder, S.; et al. Fabrication of biomimetic placental barrier structures within a microfluidic device utilizing two-photon polymerization. Int. J. Biopr. 2018, 4. [CrossRef]

23. Griep, L.M.; Wolbers, F.; de Wagenaar, B.; ter Braak, P.M.; Weksler, B.B.; Romero, I.A.; Couraud, P.O.; Vermes, I.; van der Meer, A.D.; van den Berg, A. BBB on CHIP: Microfluidic platform to mechanically and biochemically modulate blood-brain barrier function. Biomed. Microdevices 2013, 15, 145-150. [CrossRef]

24. Uzel, S.G.; Pavesi, A.; Kamm, R.D. Microfabrication and microfluidics for muscle tissue models. Prog. Biophys. Mol. Biol. 2014, 115, 279-293. [CrossRef]

25. Chan, V.; Neal, D.M.; Uzel, S.G.; Kim, H.; Bashir, R.; Asada, H.H. Fabrication and characterization of optogenetic, multi-strip cardiac muscles. Lab Chip 2015, 15, 2258-2268. [CrossRef] [PubMed]

26. Grosberg, A.; Nesmith, A.P.; Goss, J.A.; Brigham, M.D.; McCain, M.L.; Parker, K.K. Muscle on a chip: In vitro contractility assays for smooth and striated muscle. J. Pharmacol. Toxicol. Methods 2012, 65, 126-135. [CrossRef]

27. Grosberg, A.; Alford, P.W.; McCain, M.L.; Parker, K.K. Ensembles of engineered cardiac tissues for physiological and pharmacological study: Heart on a chip. Lab Chip 2011, 11, 4165-4173. [CrossRef] [PubMed]

28. Huh, D.; Matthews, B.D.; Mammoto, A.; Montoya-Zavala, M.; Yuan Hsin, H.; Ingber, D.E. Reconstituting organ-level lung functions on a chip. Science 2010, 328, 1662-1668. [CrossRef] [PubMed]

29. Park, S.H.; Sim, W.Y.; Min, B.H.; Yang, S.S.; Khademhosseini, A.; Kaplan, D.L. Chip-Based Comparison of the Osteogenesis of Human Bone Marrow- and Adipose Tissue-Derived Mesenchymal Stem Cells under Mechanical Stimulation. PLoS ONE 2012, 7. [CrossRef] [PubMed]

30. Benam, K.H.; Dauth, S.; Hassell, B.; Herland, A.; Jain, A.; Jang, K.J.; Karalis, K.; Kim, H.J.; MacQueen, L.; Mahmoodian, R.; et al. Engineered in vitro disease models. Annu. Rev. Pathol. Mech. Dis. 2015, 10, 195-262. [CrossRef]

31. Zheng, F.; Fu, F.; Cheng, Y.; Wang, C.; Zhao, Y.; Gu, Z. Organ-on-a-Chip Systems: Microengineering to Biomimic Living Systems. Small 2016, 12, 2253-2282. [CrossRef] [PubMed]

32. Mittal, R.; Woo, F.W.; Castro, C.S.; Cohen, M.A.; Karanxha, J.; Mittal, J.; Chhibber, T.; Jhaveri, V.M. Organ-on-chip models: Implications in drug discovery and clinical applications. J. Cell. Physiol. 2019, 234, 8352-8380. [CrossRef]

33. Polini, A.; Prodanov, L.; Bhise, N.S.; Manoharan, V.; Dokmeci, M.R.; Khademhosseini, A. Organs-on-a-chip: A new tool for drug discovery. Expert Opin. Drug Discov. 2014, 9, 335-352. [CrossRef] [PubMed]

34. Allwardt, V.; Ainscough, A.J.; Viswanathan, P.; Sherrod, S.D.; McLean, J.A.; Haddrick, M.; Pensabene, V. Translational Roadmap for the Organs-on-a-Chip Industry toward Broad Adoption. Bioengineering 2020, 7, 112. [CrossRef] [PubMed]

35. Rodrigues, R.O.; Sousa, P.C.; Gaspar, J.; Bañobre-López, M.; Lima, R.; Minas, G. Organ-on-a-Chip: A Preclinical Microfluidic Platform for the Progress of Nanomedicine. Small 2020, 16. [CrossRef]

36. Zhang, Y.S.; Zhang, Y.N.; Zhang, W. Cancer-on-a-chip systems at the frontier of nanomedicine. Drug Discov. Today 2017, 22, 1392-1399. [CrossRef] [PubMed]

37. Zhang, R.X.; Wong, H.L.; Xue, H.Y.; Eoh, J.Y.; Wu, X.Y. Nanomedicine of synergistic drug combinations for cancer therapyStrategies and perspectives. J. Control. Release 2016, 240, 489-503. [CrossRef]

38. Di Wu, M.S.; Xue, H.Y.; Wong, H.L. Nanomedicine applications in the treatment of breast cancer: Current state of the art. Int. J. Nanomed. 2017, 12, 5879-5892. [CrossRef]

39. Patwa, A.; Shah, A. Anatomy and physiology of respiratory system relevant to anaesthesia. Indian J. Anaesth. 2015, 59, 533. [CrossRef] [PubMed]

40. Leslie, K.O.; Wick, M.R. Lung Anatomy. Practical Pulmonary Pathology: A Diagnostic Approach; Elsevier: Amsterdam, The Netherlands, 2018; pp. 1-14.e2. ISBN 9780323442848.

41. Cowan, M.L. Diseases of the Respiratory System. In Reptile Medicine and Surgery in Clinical Practice; John Wiley \& Sons Ltd.: Hoboken, NJ, USA, 2017.

42. Matute-Bello, G.; Frevert, C.W.; Martin, T.R. Animal models of acute lung injury. Am. J. Physiol. Lung Cell. Mol. Physiol. 2008, 295, L379-L399. [CrossRef] [PubMed]

43. Moore, B.B.; Lawson, W.E.; Oury, T.D.; Sisson, T.H.; Raghavendran, K.; Hogaboam, C.M. Animal models of fibrotic lung disease. Am. J. Respir. Cell Mol. Biol. 2013, 49, 167-179. [CrossRef] [PubMed]

44. Sanderson, M.J. Exploring lung physiology in health and disease with lung slices. Pulm. Pharmacol. Ther. 2011, 24, 452-465. [CrossRef]

45. Dvornikov, D.; Zimmermann, N.; Khan, M.; Halavatyi, A.; Hessel, E.; Pöckel, D.; Beinke, S.; Pepperkok, R. An ex vivo model to study response of human COPD and non-COPD small airways to infections and therapeutic interventions. ERJ Open Res. 2019, 5, PP226. [CrossRef]

46. Coraux, C.; Nawrocki-Raby, B.; Hinnrasky, J.; Kileztky, C.; Gaillard, D.; Dani, C.; Puchelle, E. Embryonic stem cells generate airway epithelial tissue. Am. J. Respir. Cell Mol. Biol. 2005, 32, 87-92. [CrossRef]

47. Anthony, P. The Liver. Biology and Pathobiology, 5th ed.; Raven Press: Ely, MN, USA, 1988.

48. Hannan, N.R.; Sampaziotis, F.; Segeritz, C.P.; Hanley, N.A.; Vallier, L. Generation of Distal Airway Epithelium from Multipotent Human Foregut Stem Cells. Stem Cells Dev. 2015, 24, 1680-1690. [CrossRef]

49. Rock, J.R.; Randell, S.H.; Hogan, B.L. Airway basal stem cells: A perspective on their roles in epithelial homeostasis and remodeling. Dis. Models Mech. 2010, 3, 545-556. [CrossRef] 
50. Miller, A.J.; Dye, B.R.; Ferrer-Torres, D.; Hill, D.R.; Overeem, A.W.; Shea, L.D.; Spence, J.R. Generation of lung organoids from human pluripotent stem cells in vitro. Nat. Protoc. 2019, 14, 518-540. [CrossRef]

51. Huh, D.; Leslie, D.C.; Matthews, B.D.; Fraser, J.P.; Jurek, S.; Hamilton, G.A.; Thorneloe, K.S.; McAlexander, M.A.; Ingber, D.E. A human disease model of drug toxicity-induced pulmonary edema in a lung-on-a-chip microdevice. Sci. Transl. Med. 2012, 4. [CrossRef]

52. Thorneloe, K.S.; Cheung, M.; Bao, W.; Alsaid, H.; Lenhard, S.; Jian, M.-Y.; Costell, M.; Maniscalco-Hauk, K.; Krawiec, J.A.; Olzinski, A.; et al. An orally active TRPV4 channel blocker prevents and resolves pulmonary edema induced by heart failure. Sci. Transl. Med. 2012, 4, 159ra148. [CrossRef]

53. Benam, K.; Villenave, R.; Lucchesi, C. Small airway-on-a-chip enables analysis of human lung inflammation and drug responses in vitro. Nat. Methods 2016, 13, 151-157. [CrossRef]

54. Nawroth, J.C.; Lucchesi, C.; Cheng, D.; Shukla, A.; Ngyuen, J.; Shroff, T.; Varone, A.; Karalis, K.; Lee, H.-H.; Alves, S.; et al. A Microengineered Airway Lung Chip Models Key Features of Viral-induced Exacerbation of Asthma. Am. J. Respir. Cell Mol. Biol. 2020, 63, 591-600. [CrossRef]

55. Athari, S.S. Targeting cell signaling in allergic asthma. Signal Transduct. Target. Ther. 2019, 4, 45. [CrossRef]

56. Stucki, A.O.; Stucki, J.D.; Hall, S.R.; Felder, M.; Mermoud, Y.; Schmid, R.A.; Geiser, T.; Guenat, O.T. A lung-on-a-chip array with an integrated bio-inspired respiration mechanism. Lab Chip 2015, 15, 1302-1310. [CrossRef]

57. Mermoud, Y.; Felder, M.; Stucki, J.D.; Stucki, A.O.; Guenat, O.T. Microimpedance tomography system to monitor cell activity and membrane movements in a breathing lung-on-chip. Sens. Actuators B Chem. 2018, 255, 3647-3653. [CrossRef]

58. Nalayanda, D.D.; Puleo, C.; Fulton, W.B.; Sharpe, L.M.; Wang, T.H.; Abdullah, F. An open-access microfluidic model for lung-specific functional studies at an air-liquid interface. Biomed. Microdevices 2009, 11, 1081-1089. [CrossRef]

59. Bol, L.; Galas, J.C.; Hillaireau, H.; Le Potier, I.; Nicolas, V.; Haghiri-Gosnet, A.M.; Fattal, E.; Taverna, M. A microdevice for parallelized pulmonary permeability studies. Biomed. Microdevices 2014, 16, 277-285. [CrossRef]

60. Henry, O.Y.; Villenave, R.; Cronce, M.J.; Leineweber, W.D.; Benz, M.A.; Ingber, D.E. Organs-on-chips with integrated electrodes for trans-epithelial electrical resistance (TEER) measurements of human epithelial barrier function. Lab Chip 2017, 17, $2264-2271$. [CrossRef]

61. Mahto, S.K.; Tenenbaum-Katan, J.; Greenblum, A.; Rothen-Rutishauser, B.; Sznitman, J. Microfluidic shear stress-regulated surfactant secretion in alveolar epithelial type II cells in vitro. Am. J. Physiol. Lung Cell. Mol. Physiol. 2014, 306, 672-683. [CrossRef]

62. Jain, A.; Barrile, R.; van der Meer, A.D.; Mammoto, A.; Mammoto, T.; de Ceunynck, K.; Aisiku, O.; Otieno, M.A.; Louden, C.S.; Hamilton, G.A.; et al. Primary Human Lung Alveolus-on-a-chip Model of Intravascular Thrombosis for Assessment of Therapeutics. Clin. Pharmacol. Ther. 2018, 103, 332-340. [CrossRef]

63. Punde, T.H.; Wu, W.H.; Lien, P.C.; Chang, Y.L.; Kuo, P.H.; Chang, M.D.T.; Lee, K.Y.; Da Huang, C.; Kuo, H.P.; Chan, Y.F.; et al. A biologically inspired lung-on-a-chip device for the study of protein-induced lung inflammation. Integr. Biol. 2015, 7, 162-169. [CrossRef]

64. Yang, X.; Li, K.; Zhang, X.; Liu, C.; Guo, B.; Wen, W.; Gao, X. Nanofiber membrane supported lung-on-a-chip microdevice for anti-cancer drug testing. Lab Chip 2018, 18, 486-495. [CrossRef]

65. Humayun, M.; Chow, C.W.; Young, E.W. Microfluidic lung airway-on-a-chip with arrayable suspended gels for studying epithelial and smooth muscle cell interactions. Lab Chip 2018, 18, 1298-1309. [CrossRef] [PubMed]

66. Zuchowska, A.; Jastrzebska, E.; Chudy, M.; Dybko, A.; Brzozka, Z. 3D lung spheroid cultures for evaluation of photodynamic therapy (PDT) procedures in microfluidic Lab-on-a-Chip system. Anal. Chim. Acta 2017, 990, 110-120. [CrossRef]

67. Alexander, F.A.; Eggert, S.; Wiest, J. Skin-on-a-chip: Transepithelial electrical resistance and extracellular acidification measurements through an automated air-liquid interface. Genes 2018, 9, 114. [CrossRef]

68. Sriram, G.; Alberti, M.; Dancik, Y.; Wu, B.; Wu, R.; Feng, Z.; Ramasamy, S.; Bigliardi, P.L.; Bigliardi-Qi, M.; Wang, Z. Full-thickness human skin-on-chip with enhanced epidermal morphogenesis and barrier function. Mater. Today 2018, 21, 326-340. [CrossRef]

69. Mori, N.; Morimoto, Y.; Takeuchi, S. Skin integrated with perfusable vascular channels on a chip. Biomaterials 2017, 116, 48-56. [CrossRef]

70. Lee, S.; Jin, S.P.; Kim, Y.K.; Sung, G.Y.; Chung, J.H.; Sung, J.H. Construction of 3D multicellular microfluidic chip for an in vitro skin model. Biomed. Microdevices 2017, 19, 22. [CrossRef]

71. Alberti, M.; Dancik, Y.; Sriram, G.; Wu, B.; Teo, Y.L.; Feng, Z.; Bigliardi-Qi, M.; Wu, R.G.; Wang, Z.P.; Bigliardi, P.L. Multi-chamber microfluidic platform for high-precision skin permeation testing. Lab Chip 2017, 17, 1625-1634. [CrossRef] [PubMed]

72. Song, H.J.; Lim, H.Y.; Chun, W.; Choi, K.C.; Sung, J.H.; Sung, G.Y. Fabrication of a pumpless, microfluidic skin chip from different collagen sources. J. Ind. Eng. Chem. 2017, 56, 375-381. [CrossRef]

73. Abaci, H.E.; Gledhill, K.; Guo, Z.; Christiano, A.M.; Shuler, M.L. Pumpless microfluidic platform for drug testing on human skin equivalents. Lab Chip 2015, 15, 882-888. [CrossRef]

74. Wufuer, M.; Lee, G.H.; Hur, W.; Jeon, B.; Kim, B.J.; Choi, T.H.; Lee, S.H. Skin-on-a-chip model simulating inflammation, edema and drug-based treatment. Sci. Rep. 2016, 6. [CrossRef]

75. Ramadan, Q.; Ting, F.C.W. In vitro micro-physiological immune-competent model of the human skin. Lab Chip 2016, 16, 1899-1908. [CrossRef] 
76. Yuki, T.; Hachiya, A.; Kusaka, A.; Sriwiriyanont, P.; Visscher, M.O.; Morita, K.; Muto, M.; Miyachi, Y.; Sugiyama, Y.; Inoue, S. Characterization of tight junctions and their disruption by UVB in human epidermis and cultured keratinocytes. J. Investig. Dermatol. 2011, 131, 744-752. [CrossRef] [PubMed]

77. Jackson, E.; Shoemaker, R.; Larian, N.; Cassis, L. Adipose tissue as a site of toxin accumulation. Compr. Physiol. 2017, 7, 1085-1135. [CrossRef]

78. Loskill, P.; Sezhian, T.; Tharp, K.M.; Lee-Montiel, F.T.; Jeeawoody, S.; Reese, W.M.; Zushin, P.J.H.; Stahl, A.; Healy, K.E. WATon-a-chip: A physiologically relevant microfluidic system incorporating white adipose tissue. Lab Chip 2017, 17, 1645-1654. [CrossRef]

79. Vidal, S.E.; Tamamoto, K.A.; Nguyen, H.; Abbott, R.D.; Cairns, D.M.; Kaplan, D.L. 3D biomaterial matrix to support long term, full thickness, immuno-competent human skin equivalents with nervous system components. Biomaterials 2019, 198, 194-203. [CrossRef]

80. Lee, J.; Rabbani, C.C.; Gao, H.; Steinhart, M.R.; Woodruff, B.M.; Pflum, Z.E.; Kim, A.; Heller, S.; Liu, Y.; Shipchandler, T.Z.; et al. Hair-bearing human skin generated entirely from pluripotent stem cells. Nature 2020, 582, 399-404. [CrossRef] [PubMed]

81. Kuehlmann, B.; Bonham, C.A.; Zucal, I.; Prantl, L.; Gurtner, G.C. Mechanotransduction in Wound Healing and Fibrosis. J. Clin. Med. 2020, 9, 1423. [CrossRef] [PubMed]

82. Peters, A.S.; Brunner, G.; Krieg, T.; Eckes, B. Cyclic mechanical strain induces TGF $\beta 1$-signalling in dermal fibroblasts embedded in a 3D collagen lattice. Arch. Dermatol. Res. 2015, 307, 191-197. [CrossRef]

83. Du, Y.; Li, N.; Long, M. Liver sinusoid on a chip. Methods Cell Biol. 2018, 146, 105-134. [CrossRef]

84. Almazroo, O.A.; Miah, M.K.; Venkataramanan, R. Drug Metabolism in the Liver. Clin. Liver Dis. 2017, 21, 1-20. [CrossRef]

85. Michalopoulos, G.K. Liver regeneration. J. Cell. Physiol. 2007, 213, 286-300. [CrossRef]

86. Taub, R. Liver regeneration: From myth to mechanism. Nat. Rev. Mol. Cell Biol. 2004, 5, 836-847. [CrossRef]

87. Cole, B.K.; Feaver, R.E.; Wamhoff, B.R.; Dash, A. Non-alcoholic fatty liver disease (NAFLD) models in drug discovery. Expert Opin. Drug Discov. 2018, 13, 193-205. [CrossRef] [PubMed]

88. Palma, E.; Doornebal, E.J.; Chokshi, S. Precision-cut liver slices: A versatile tool to advance liver research. Hepatol. Int. 2019, 13, 51-57. [CrossRef] [PubMed]

89. Lau, J.K.C.; Zhang, X.; Yu, J. Animal models of non-alcoholic fatty liver disease: Current perspectives and recent advances. J. Pathol. 2017, 241, 36-44. [CrossRef] [PubMed]

90. Anstee, Q.M.; Goldin, R.D. Mouse models in non-alcoholic fatty liver disease and steatohepatitis research. Int. J. Exp. Pathol. 2006, 87, 1-16. [CrossRef]

91. Novik, E.I.; Dwyer, J.; Morelli, J.K.; Parekh, A.; Cho, C.; Pludwinski, E.; Shrirao, A.; Freedman, R.M.; MacDonald, J.S.; Jayyosi, Z. Long-enduring primary hepatocyte-based co-cultures improve prediction of hepatotoxicity. Toxicol. Appl. Pharmacol. 2017, 336, 20-30. [CrossRef]

92. Vaja, R.; Ghuman, N. Drugs and the liver. Anaesth. Intensiv. Care Med. 2018, 19, 30-34. [CrossRef]

93. Lee, J.; Kim, S.H.; Kim, Y.C.; Choi, I.; Sung, J.H. Fabrication and characterization of microfluidic liver-on-a-chip using microsomal enzymes. Enzym. Microb. Technol. 2013, 53, 159-164. [CrossRef] [PubMed]

94. Lee, K.H.; Lee, J.; Lee, S.H. 3D liver models on a microplatform: Well-defined culture, engineering of liver tissue and liver-on-achip. Lab Chip 2015, 15, 3822-3837. [CrossRef]

95. Christoffersson, J.; Aronsson, C.; Jury, M.; Selegård, R.; Aili, D.; Mandenius, C.F. Fabrication of modular hyaluronan-PEG hydrogels to support 3D cultures of hepatocytes in a perfused liver-on-a-chip device. Biofabrication 2019, 11. [CrossRef]

96. Chang, S.Y.; Voellinger, J.L.; van Ness, K.P.; Chapron, B.; Shaffer, R.M.; Neumann, T.; White, C.C.; Kavanagh, T.J.; Kelly, E.J.; Eaton, D.L. Characterization of rat or human hepatocytes cultured in microphysiological systems (MPS) to identify hepatotoxicity. Toxicol. Vitr. 2017, 40, 170-183. [CrossRef] [PubMed]

97. Lee, S.A.; Da No, Y.; Kang, E.; Ju, J.; Kim, D.S.; Lee, S.H. Spheroid-based three-dimensional liver-on-a-chip to investigate hepatocyte-hepatic stellate cell interactions and flow effects. Lab Chip 2013, 13, 3529-3537. [CrossRef] [PubMed]

98. Kamei, K.i.; Yoshioka, M.; Terada, S.; Tokunaga, Y.; Chen, Y. Three-dimensional cultured liver-on-a-Chip with mature hepatocytelike cells derived from human pluripotent stem cells. Biomed. Microdevices 2019, 21, 73. [CrossRef] [PubMed]

99. Deng, J.; Chen, Z.; Zhang, X.; Luo, Y.; Wu, Z.; Lu, Y.; Liu, T.; Zhao, W.; Lin, B. A liver-chip-based alcoholic liver disease model featuring multi-non-parenchymal cells. Biomed. Microdevices 2019, 21, 57. [CrossRef] [PubMed]

100. Prodanov, L.; Jindal, R.; Bale, S.S.; Hegde, M.; Mccarty, W.J.; Golberg, I.; Bhushan, A.; Yarmush, M.L.; Usta, O.B. Long-term maintenance of a microfluidic 3D human liver sinusoid. Biotechnol. Bioeng. 2016, 113, 241-246. [CrossRef]

101. Li, X.; George, S.M.; Vernetti, L.; Gough, A.H.; Taylor, D.L. A glass-based, continuously zonated and vascularized human liver acinus microphysiological system (vLAMPS) designed for experimental modeling of diseases and ADME/TOX. Lab Chip 2018, 18, 2614-2631. [CrossRef]

102. Kang, Y.B.A.; Sodunke, T.R.; Lamontagne, J.; Cirillo, J.; Rajiv, C.; Bouchard, M.J.; Noh, M. Liver sinusoid on a chip: Long-term layered co-culture of primary rat hepatocytes and endothelial cells in microfluidic platforms. Biotechnol. Bioeng. 2015, 112, 2571-2582. [CrossRef]

103. Ortega-Ribera, M.; Fernández-Iglesias, A.; Illa, X.; Moya, A.; Molina, V.; Maeso-Díaz, R.; Fondevila, C.; Peralta, C.; Bosch, J.; Villa, R.; et al. Resemblance of the human liver sinusoid in a fluidic device with biomedical and pharmaceutical applications. Biotechnol Bioeng. 2018, 115, 2585-2594. [CrossRef] 
104. Liu, J.; Li, R.; Xue, R.; Li, T.; Leng, L.; Wang, Y.; Wang, J.; Ma, J.; Yan, J.; Yan, F.; et al. Liver Extracellular Matrices Bioactivated Hepatic Spheroids as a Model System for Drug Hepatotoxicity Evaluations. Adv. Biosys. 2018, 2, 1800110. [CrossRef]

105. Albrecht, W.; Kappenberg, F.; Brecklinghaus, T.; Stoeber, R.; Marchan, R.; Zhang, M.; Ebbert, K.; Kirschner, H.; Grinberg, M.; Leist, M.; et al. Prediction of human drug-induced liver injury (DILI) in relation to oral doses and blood concentrations. Arch. Toxicol. 2019, 93, 1609-1637. [CrossRef] [PubMed]

106. Jang, K.-J.; Otieno, M.A.; Ronxhi, J.; Lim, H.-K.; Ewart, L.; Kodella, K.R.; Petropolis, D.B.; Kulkarni, G.; Rubins, J.E.; Conegliano, D.; et al. Reproducing human and cross-species drug toxicities using a Liver-Chip. Sci. Transl. Med. 2019, 11. [CrossRef] [PubMed]

107. Uchino, S.; Kellum, J.A.; Bellomo, R.; Doig, G.S.; Morimatsu, H.; Morgera, S.; Schetz, M.; Tan, I.; Bouman, C.; Macedo, E.; et al. Acute renal failure in critically ill patients: A multinational, multicenter study. J. Am. Med Assoc. 2005, 294, 813-818. [CrossRef] [PubMed]

108. Nieskens, T.T.; Sjögren, A.K. Emerging In Vitro Systems to Screen and Predict Drug-Induced Kidney Toxicity. Semin. Nephrol. 2019, 39, 215-226. [CrossRef]

109. Lee, J.; Kim, S. Kidney-on-a-Chip: A New Technology for Predicting Drug Efficacy, Interactions, and Drug-induced Nephrotoxicity. Curr. Drug Metab. 2018, 19, 577-583. [CrossRef] [PubMed]

110. Weber, E.J.; Chapron, A.; Chapron, B.D.; Voellinger, J.L.; Lidberg, K.A.; Yeung, C.K.; Wang, Z.; Yamaura, Y.; Hailey, D.W.; Neumann, T; et al. Development of a microphysiological model of human kidney proximal tubule function. Kidney Int. 2016, 90, 627-637. [CrossRef] [PubMed]

111. Wilmer, M.J.; Ng, C.P.; Lanz, H.L.; Vulto, P.; Suter-Dick, L.; Masereeuw, R. Kidney-on-a-Chip Technology for Drug-Induced Nephrotoxicity Screening. Trends Biotechnol. 2016, 34, 156-170. [CrossRef] [PubMed]

112. Rayner, S.G.; Phong, K.T.; Xue, J.; Lih, D.; Shankland, S.J.; Kelly, E.J.; Himmelfarb, J.; Zheng, Y. Reconstructing the Human Renal Vascular-Tubular Unit In Vitro. Adv. Healthc. Mater. 2018, 7, e1801120. [CrossRef]

113. Homan, K.A.; Gupta, N.; Kroll, K.T.; Kolesky, D.B.; Skylar-Scott, M.; Miyoshi, T.; Mau, D.; Valerius, M.T.; Ferrante, T.; Bonventre, J.V.; et al. Flow-enhanced vascularization and maturation of kidney organoids in vitro. Nat. Methods 2019, 16, 255-262. [CrossRef]

114. Kim, S.; LesherPerez, S.C.; Kim, B.C.C.; Yamanishi, C.; Labuz, J.M.; Leung, B.; Takayama, S. Pharmacokinetic profile that reduces nephrotoxicity of gentamicin in a perfused kidney-on-a-chip. Biofabrication 2016, 8, 15021. [CrossRef]

115. Vormann, M.K.; Gijzen, L.; Hutter, S.; Boot, L.; Nicolas, A.; van den Heuvel, A.; Vriend, J.; Ng, C.P.; Nieskens, T.T.; van Duinen, V.; et al. Nephrotoxicity and Kidney Transport Assessment on 3D Perfused Proximal Tubules. AAPS J. 2018, 20, 90. [CrossRef]

116. Li, Z.; Jiang, L.; Tao, T.; Su, W.; Guo, Y.; Yu, H.; Qin, J. Assessment of cadmium-induced nephrotoxicity using a kidney-on-a-chip device. Toxicol. Res. 2017, 6, 372-380. [CrossRef] [PubMed]

117. Huang, H.C.; Chang, Y.J.; Chen, W.C.; Harn, H.I.; Tang, M.J.; Wu, C.C. Enhancement of renal epithelial cell functions through microfluidic-based coculture with adipose-derived stem cells. Tissue Eng. Part A 2013, 19, 2024-2034. [CrossRef] [PubMed]

118. Savoji, H.; Mohammadi, M.H.; Rafatian, N.; Toroghi, M.K.; Wang, E.Y.; Zhao, Y.; Korolj, A.; Ahadian, S.; Radisic, M. Cardiovascular disease models: A game changing paradigm in drug discovery and screening. Biomaterials 2019, 198, 3-26. [CrossRef] [PubMed]

119. de Hert, M.; Detraux, J.; van Winkel, R.; Yu, W.; Correll, C.U. Metabolic and cardiovascular adverse effects associated with antipsychotic drugs. Nat. Rev. Endocrinol. 2012, 8, 114-126. [CrossRef] [PubMed]

120. Brown, S.A.; Sandhu, N.; Herrmann, J. Systems biology approaches to adverse drug effects: The example of cardio-oncology. Nat. Rev. Clin. Oncol. 2015, 12, 718-731. [CrossRef] [PubMed]

121. Ellis, B.W.; Acun, A.; Isik Can, U.; Zorlutuna, P. Human IPSC-derived myocardium-on-chip with capillary-like flow for personalized medicine. Biomicrofluidics 2017, 11, 24105. [CrossRef] [PubMed]

122. Tomecka, E.; Zukowski, K.; Jastrzebska, E.; Chudy, M.; Brzozka, Z. Microsystem with micropillar array for three- (gel-embaded) and two-dimensional cardiac cell culture. Sens. Actuators B Chem. 2018, 254, 973-983. [CrossRef]

123. Zhang, X.; Wang, T.; Wang, P.; Hu, N. High-throughput assessment of drug cardiac safety using a high-speed impedance detection technology-based heart-on-a-chip. Micromachines 2016, 7, 122. [CrossRef]

124. Tandon, N.; Cannizzaro, C.; Chao, P.H.G.; Maidhof, R.; Marsano, A.; Au, H.T.H.; Radisic, M.; Vunjak-Novakovic, G. Electrical stimulation systems for cardiac tissue engineering. Nat. Protoc. 2009, 4, 155-173. [CrossRef]

125. Stoppel, W.L.; Kaplan, D.L.; Black, L.D. Electrical and mechanical stimulation of cardiac cells and tissue constructs. Adv. Drug Deliv. Rev. 2016, 96, 135-155. [CrossRef] [PubMed]

126. Marsano, A.; Conficconi, C.; Lemme, M.; Occhetta, P.; Gaudiello, E.; Votta, E.; Cerino, G.; Redaelli, A.; Rasponi, M. Beating heart on a chip: A novel microfluidic platform to generate functional 3D cardiac microtissues. Lab Chip 2016, 16, 599-610. [CrossRef]

127. Hansen, A.; Eder, A.; Bönstrup, M.; Flato, M.; Mewe, M.; Schaaf, S.; Aksehirlioglu, B.; Schwoerer, A.; Uebeler, J.; Eschenhagen, T. Erratum: Development of a drug screening platform based on engineered heart tissue. Circ. Res. 2011, 109, 35. [CrossRef]

128. Ahn, S.; Ardoña, H.A.M.; Lind, J.U.; Eweje, F.; Kim, S.L.; Gonzalez, G.M.; Liu, Q.; Zimmerman, J.F.; Pyrgiotakis, G.; Zhang, Z.; et al. Mussel-inspired 3D fiber scaffolds for heart-on-a-chip toxicity studies of engineered nanomaterials. Anal. Bioanal. Chem. 2018, 410, 6141-6154. [CrossRef]

129. Agarwal, A.; Goss, J.A.; Cho, A.; McCain, M.L.; Parker, K.K. Microfluidic heart on a chip for higher throughput pharmacological studies. Lab Chip 2013, 13, 3599-3608. [CrossRef] [PubMed] 
130. Lind, J.U.; Busbee, T.A.; Valentine, A.D.; Pasqualini, F.S.; Yuan, H.; Yadid, M.; Park, S.J.; Kotikian, A.; Nesmith, A.P.; Campbell, P.H.; et al. Instrumented cardiac microphysiological devices via multimaterial three-dimensional printing. Nat. Mater. 2017, 16, 303-308. [CrossRef]

131. Stancescu, M.; Molnar, P.; McAleer, C.W.; McLamb, W.; Long, C.J.; Oleaga, C.; Prot, J.M.; Hickman, J.J. A phenotypic invitro model for the main determinants of human whole heart function. Biomaterials 2015, 60, 20-30. [CrossRef]

132. Zhang, Y.S.; Arneri, A.; Bersini, S.; Shin, S.R.; Zhu, K.; Goli-Malekabadi, Z.; Aleman, J.; Colosi, C.; Busignani, F.; Dell’Erba, V.; et al. Bioprinting 3D microfibrous scaffolds for engineering endothelialized myocardium and heart-on-a-chip. Biomaterials 2016, 110, 45-59. [CrossRef] [PubMed]

133. Swartz, M.A. The physiology of the lymphatic system. Adv. Drug Deliv. Rev. 2001, 50, 3-20. [CrossRef]

134. Cochrane, A.; Albers, H.J.; Passier, R.; Mummery, C.L.; van den Berg, A.; Orlova, V.V.; van der Meer, A.D. Advanced in vitro models of vascular biology: Human induced pluripotent stem cells and organ-on-chip technology. Adv. Drug Deliv. Rev. 2019, 140, 68-77. [CrossRef]

135. Haase, K.; Kamm, R.D. Advances in on-chip vascularization. Regen. Med. 2017, 12, 285-302. [CrossRef]

136. Chen, M.B.; Whisler, J.A.; Fröse, J.; Yu, C.; Shin, Y.; Kamm, R.D. On-chip human microvasculature assay for visualization and quantification of tumor cell extravasation dynamics. Nat. Protoc. 2017, 12, 865-880. [CrossRef] [PubMed]

137. Pisano, M.; Triacca, V.; Barbee, K.A.; Swartz, M.A. An in vitro model of the tumor-lymphatic microenvironment with simultaneous transendothelial and luminal flows reveals mechanisms of flow enhanced invasion. Integr. Biol. 2015, 7, 525-533. [CrossRef] [PubMed]

138. Kim, S.; Kim, W.; Lim, S.; Jeon, J.S. Vasculature-on-a-chip for in vitro disease models. Bioengineering 2017, 4, 8. [CrossRef] [PubMed]

139. Costa, P.F.; Albers, H.J.; Linssen, J.E.; Middelkamp, H.H.; van der Hout, L.; Passier, R.; van den Berg, A.; Malda, J.; van der Meer, A.D. Mimicking arterial thrombosis in a 3D-printed microfluidic: In vitro vascular model based on computed tomography angiography data. Lab Chip 2017, 17, 2785-2792. [CrossRef]

140. Choi, J.S.; Seo, T.S. Orthogonal co-cultivation of smooth muscle cell and endothelial cell layers to construct in vivo-like vasculature. Biomicrofluidics 2019, 13. [CrossRef] [PubMed]

141. Rathod, M.L.; Ahn, J.; Jeon, N.L.; Lee, J. Hybrid polymer microfluidic platform to mimic varying vascular compliance and topology. Lab Chip 2017, 17, 2508-2516. [CrossRef] [PubMed]

142. Fenech, M.; Girod, V.; Claveria, V.; Meance, S.; Abkarian, M.; Charlot, B. Microfluidic blood vasculature replicas using backside lithography. Lab Chip 2019, 19, 2096-2106. [CrossRef] [PubMed]

143. Nie, J.; Gao, Q.; Wang, Y.; Zeng, J.; Zhao, H.; Sun, Y.; Shen, J.; Ramezani, H.; Fu, Z.; Liu, Z.; et al. Vessel-on-a-chip with Hydrogel-based Microfluidics. Small 2018, 14. [CrossRef]

144. He, J.; Chen, R.; Lu, Y.; Zhan, L.; Liu, Y.; Li, D.; Jin, Z. Fabrication of circular microfluidic network in enzymatically-crosslinked gelatin hydrogel. Mater. Sci. Eng. C 2016, 59, 53-60. [CrossRef]

145. Cueni, L.N.; Detmar, M. New insights into the molecular control of the lymphatic vascular system and its role in disease. J. Invest. Dermatol. 2006, 126, 2167-2177. [CrossRef] [PubMed]

146. Menon, N.V.; Tay, H.M.; Wee, S.N.; Li, K.H.H.; Hou, H.W. Micro-engineered perfusable 3D vasculatures for cardiovascular diseases. Lab Chip 2017, 17, 2960-2968. [CrossRef] [PubMed]

147. Zhang, B.; Montgomery, M.; Chamberlain, M.D.; Ogawa, S.; Korolj, A.; Pahnke, A.; Wells, L.A.; Masse, S.; Kim, J.; Reis, L.; et al. Biodegradable scaffold with built-in vasculature for organ-on-a-chip engineering and direct surgical anastomosis. Nat. Mater. 2016, 15, 669-678. [CrossRef] [PubMed]

148. Chrobak, K.M.; Potter, D.R.; Tien, J. Formation of perfused, functional microvascular tubes in vitro. Microvasc. Res. 2006, 71, 185-196. [CrossRef]

149. DeOre, B.J.; Galie, P.A.; Sehgal, C.M. Fluid flow rate dictates the efficacy of low-intensity anti-vascular ultrasound therapy in a microfluidic model. Microcirculation 2019, 26. [CrossRef]

150. Kinoshita, K.; Iwase, M.; Yamada, M.; Yajima, Y.; Seki, M. Fabrication of multilayered vascular tissues using microfluidic agarose hydrogel platforms. Biotechnol. J. 2016, 11, 1415-1423. [CrossRef]

151. Tan, A.; Fujisawa, K.; Yukawa, Y.; Matsunaga, Y.T. Bottom-up fabrication of artery-mimicking tubular co-cultures in collagen-based microchannel scaffolds. Biomater. Sci. 2016, 4, 1503-1514. [CrossRef]

152. Polacheck, W.J.; Kutys, M.L.; Tefft, J.B.; Chen, C.S. Microfabricated blood vessels for modeling the vascular transport barrier. Nat. Protoc. 2019, 14, 1425-1454. [CrossRef]

153. Alimperti, S.; Mirabella, T.; Bajaj, V.; Polacheck, W.; Pirone, D.M.; Duffield, J.; Eyckmans, J.; Assoian, R.K.; Chen, C.S. Threedimensional biomimetic vascular model reveals a RhoA, Rac1, and N-cadherin balance in mural cell-endothelial cell-regulated barrier function. Proc. Natl. Acad. Sci. USA 2017, 114, 8758-8763. [CrossRef]

154. Gong, M.M.; Lugo-Cintron, K.M.; White, B.R.; Kerr, S.C.; Harari, P.M.; Beebe, D.J. Human organotypic lymphatic vessel model elucidates microenvironment-dependent signaling and barrier function. Biomaterials 2019, 214. [CrossRef]

155. Bischel, L.L.; Lee, S.-H.; Beebe, D.J. A practical method for patterning lumens through ECM hydrogels via viscous finger patterning. J. Lab. Autom. 2012, 17, 96-103. [CrossRef]

156. de Graaf, M.N.S.; Cochrane, A.; van den Hil, F.E.; Buijsman, W.; van der Meer, A.D.; van den Berg, A.; Mummery, C.L.; Orlova, V.V. Scalable microphysiological system to model three-dimensional blood vessels. APL Bioeng. 2019, 3, 26105. [CrossRef] 
157. Whisler, J.A.; Chen, M.B.; Kamm, R.D. Control of perfusable microvascular network morphology using a multiculture microfluidic system. Tissue Eng. Part C Methods 2014, 20, 543-552. [CrossRef] [PubMed]

158. Kim, S.; Chung, M.; Ahn, J.; Lee, S.; Jeon, N.L. Interstitial flow regulates the angiogenic response and phenotype of endothelial cells in a 3D culture model. Lab Chip 2016, 16, 4189-4199. [CrossRef] [PubMed]

159. Abe, Y.; Watanabe, M.; Chung, S.; Kamm, R.D.; Tanishita, K.; Sudo, R. Balance of interstitial flow magnitude and vascular endothelial growth factor concentration modulates three-dimensional microvascular network formation. APL Bioeng. $2019,3$. [CrossRef]

160. Kim, S.; Chung, M.; Jeon, N.L. Three-dimensional biomimetic model to reconstitute sprouting lymphangiogenesis in vitro. Biomaterials 2016, 78, 115-128. [CrossRef] [PubMed]

161. Offeddu, G.S.; Haase, K.; Gillrie, M.R.; Li, R.; Morozova, O.; Hickman, D.; Knutson, C.G.; Kamm, R.D. An on-chip model of protein paracellular and transcellular permeability in the microcirculation. Biomaterials 2019, 212, 115-125. [CrossRef] [PubMed]

162. Zeinali, S.; Bichsel, C.A.; Hobi, N.; Funke, M.; Marti, T.M.; Schmid, R.A.; Guenat, O.T.; Geiser, T. Human microvasculature-on-a chip: Anti-neovasculogenic effect of nintedanib in vitro. Angiogenesis 2018, 21, 861-871. [CrossRef]

163. Ahn, J.; Cho, C.S.; Cho, S.W.; Kang, J.H.; Kim, S.Y.; Min, D.H.; Song, J.M.; Park, T.E.; Jeon, N.L. Investigation on vascular cytotoxicity and extravascular transport of cationic polymer nanoparticles using perfusable 3D microvessel model. Acta Biomater. 2018, 76, 154-163. [CrossRef] [PubMed]

164. Li, Y.; Wu, Y.; Liu, Y.; Deng, Q.H.; Mak, M.; Yang, X. Atmospheric nanoparticles affect vascular function using a 3D human vascularized organotypic chip. Nanoscale 2019, 11, 15537-15549. [CrossRef]

165. Phan, D.T.T.; Wang, X.; Craver, B.M.; Sobrino, A.; Zhao, D.; Chen, J.C.; Lee, L.Y.N.; George, S.C.; Lee, A.P.; Hughes, C.C.W. A vascularized and perfused organ-on-a-chip platform for large-scale drug screening applications. Lab Chip 2017, 17, 511-520. [CrossRef] [PubMed]

166. Sobrino, A.; Phan, D.T.T.; Datta, R.; Wang, X.; Hachey, S.J.; Romero-López, M.; Gratton, E.; Lee, A.P.; George, S.C.; Hughes, C.C.W. 3D microtumors in vitro supported by perfused vascular networks. Sci. Rep. 2016, 6, 31589. [CrossRef] [PubMed]

167. Abbott, N.J.; Patabendige, A.A.; Dolman, D.E.; Yusof, S.R.; Begley, D.J. Structure and function of the blood-brain barrier. Neurobiol. Dis. 2010, 37, 13-25. [CrossRef] [PubMed]

168. Pardridge, W.M. The blood-brain barrier: Bottleneck in brain drug development. NeuroRx 2005, 2, 3-14. [CrossRef] [PubMed]

169. Sellgren, K.L.; Hawkins, B.T.; Grego, S. An optically transparent membrane supports shear stress studies in a three-dimensional microfluidic neurovascular unit model. Biomicrofluidics 2015, 9. [CrossRef] [PubMed]

170. Falanga, A.P.; Melone, P.; Cagliani, R.; Borbone, N.; D’Errico, S.; Piccialli, G.; Netti, P.A.; Guarnieri, D. Design, synthesis and characterization of novel co-polymers decorated with peptides for the selective nanoparticle transport across the cerebral endothelium. Molecules 2018, 23, 1655. [CrossRef] [PubMed]

171. Brown, J.A.; Pensabene, V.; Markov, D.A.; Allwardt, V.; Diana Neely, M.; Shi, M.; Britt, C.M.; Hoilett, O.S.; Yang, Q.; Brewer, B.M.; et al. Recreating blood-brain barrier physiology and structure on chip: A novel neurovascular microfluidic bioreactor. Biomicrofluidics 2015, 9, 54124. [CrossRef]

172. Maoz, B.M.; Herland, A.; FitzGerald, E.A.; Grevesse, T.; Vidoudez, C.; Pacheco, A.R.; Sheehy, S.P.; Park, T.E.; Dauth, S.; Mannix, R.; et al. A linked organ-on-chip model of the human neurovascular unit reveals the metabolic coupling of endothelial and neuronal cells. Nat. Biotechnol. 2018, 36, 865-877. [CrossRef]

173. Park, T.E.; Mustafaoglu, N.; Herland, A.; Hasselkus, R.; Mannix, R.; FitzGerald, E.A.; Prantil-Baun, R.; Watters, A.; Henry, O.; Benz, M.; et al. Hypoxia-enhanced Blood-Brain Barrier Chip recapitulates human barrier function and shuttling of drugs and antibodies. Nat. Commun. 2019, 10. [CrossRef]

174. Deosarkar, S.P.; Prabhakarpandian, B.; Wang, B.; Sheffield, J.B.; Krynska, B.; Kiani, M.F. A novel dynamic neonatal blood-brain barrier on a chip. PLoS ONE 2015, 10, e0142725. [CrossRef]

175. Terrell-Hall, T.B.; Ammer, A.G.; Griffith, J.I.; Lockman, P.R. Permeability across a novel microfluidic blood-tumor barrier model. Fluids Barriers CNS 2017, 14, 3. [CrossRef]

176. Adriani, G.; Ma, D.; Pavesi, A.; Kamm, R.D.; Goh, E.L. A 3D neurovascular microfluidic model consisting of neurons, astrocytes and cerebral endothelial cells as a blood-brain barrier. Lab Chip 2017, 17, 448-459. [CrossRef]

177. Wevers, N.R.; Kasi, D.G.; Gray, T.; Wilschut, K.J.; Smith, B.; Vught, R.; Shimizu, F.; Sano, Y.; Kanda, T.; Marsh, G.; et al. A perfused human blood-brain barrier on-a-chip for high-throughput assessment of barrier function and antibody transport. Fluids Barriers CNS 2018, 15, 23. [CrossRef]

178. Kim, J.A.; Kim, H.N.; Im, S.K.; Chung, S.; Kang, J.Y.; Choi, N. Collagen-based brain microvasculature model in vitro using three-dimensional printed template. Biomicrofluidics 2015, 9. [CrossRef] [PubMed]

179. Cho, H.; Seo, J.H.; Wong, K.H.; Terasaki, Y.; Park, J.; Bong, K.; Arai, K.; Lo, E.H.; Irimia, D. Three-dimensional blood-brain barrier model for in vitro studies of neurovascular pathology. Sci. Rep. 2015, 5. [CrossRef] [PubMed]

180. Herland, A.; van der Meer, A.D.; FitzGerald, E.A.; Park, T.E.; Sleeboom, J.J.; Ingber, D.E. Distinct contributions of astrocytes and pericytes to neuroinflammation identified in a 3D human blood-brain barrier on a chip. PLoS ONE 2016, 11, e0150360. [CrossRef] [PubMed]

181. Bang, S.; Lee, S.R.; Ko, J.; Son, K.; Tahk, D.; Ahn, J.; Im, C.; Jeon, N.L. A Low Permeability Microfluidic Blood-Brain Barrier Platform with Direct Contact between Perfusable Vascular Network and Astrocytes. Sci. Rep. 2017, 7, 1-10. [CrossRef] [PubMed] 
182. Campisi, M.; Shin, Y.; Osaki, T.; Hajal, C.; Chiono, V.; Kamm, R.D. 3D self-organized microvascular model of the human blood-brain barrier with endothelial cells, pericytes and astrocytes. Biomaterials 2018, 180, 117-129. [CrossRef] [PubMed]

183. Mastorakos, P.; McGavern, D. The anatomy and immunology of vasculature in the central nervous system. Sci. Immunol. 2019, 4. [CrossRef] [PubMed]

184. Dauth, S.; Maoz, B.M.; Sheehy, S.P.; Hemphill, M.A.; Murty, T.; Macedonia, M.K.; Greer, A.M.; Budnik, B.; Parker, K.K. Neurons derived from different brain regions are inherently different in vitro: A novel multiregional brain-on-a-chip. J. Neurophysiol. 2017, 117, 1320-1341. [CrossRef] [PubMed]

185. Bang, S.; Na, S.; Jang, J.M.; Kim, J.; Jeon, N.L. Engineering-Aligned 3D Neural Circuit in Microfluidic Device. Adv. Healthc. Mater. 2016, 5, 159-166. [CrossRef]

186. Sances, S.; Ho, R.; Vatine, G.; West, D.; Laperle, A.; Meyer, A.; Godoy, M.; Kay, P.S.; Mandefro, B.; Hatata, S.; et al. Human iPSC-Derived Endothelial Cells and Microengineered Organ-Chip Enhance Neuronal Development. Stem Cell Rep. 2018, 10, 1222-1236. [CrossRef]

187. MacKerron, C.; Robertson, G.; Zagnoni, M.; Bushell, T.J. A Microfluidic Platform for the Characterisation of CNS Active Compounds. Sci. Rep. 2017, 7. [CrossRef]

188. Takahashi, K.; Yamanaka, S. Induction of Pluripotent Stem Cells from Mouse Embryonic and Adult Fibroblast Cultures by Defined Factors. Cell 2006, 126, 663-676. [CrossRef]

189. Wang, Y.; Wang, L.; Guo, Y.; Zhu, Y.; Qin, J. Engineering stem cell-derived 3D brain organoids in a perfusable organ-on-a-chip system. RSC Adv. 2018, 8, 1677-1685. [CrossRef]

190. Wang, Y.; Wang, L.; Zhu, Y.; Qin, J. Human brain organoid-on-a-chip to model prenatal nicotine exposure. Lab Chip 2018, 18, 851-860. [CrossRef]

191. Karzbrun, E.; Kshirsagar, A.; Cohen, S.R.; Hanna, J.H.; Reiner, O. Human brain organoids on a chip reveal the physics of folding. Nat. Phys. 2018, 14, 515-522. [CrossRef]

192. Zhu, Y.; Wang, L.; Yu, H.; Yin, F.; Wang, Y.; Liu, H.; Jiang, L.; Qin, J. In situ generation of human brain organoids on a micropillar array. Lab Chip 2017, 17, 2941-2950. [CrossRef] [PubMed]

193. Koo, Y.; Hawkins, B.T.; Yun, Y. Three-dimensional (3D) tetra-culture brain on chip platform for organophosphate toxicity screening. Sci. Rep. 2018, 8. [CrossRef] [PubMed]

194. Materne, E.M.; Ramme, A.P.; Terrasso, A.P.; Serra, M.; Alves, P.M.; Brito, C.; Sakharov, D.A.; Tonevitsky, A.G.; Lauster, R.; Marx, U. A multi-organ chip co-culture of neurospheres and liver equivalents for long-term substance testing. J. Biotechnol. 2015, 205, 36-46. [CrossRef] [PubMed]

195. Lei, Y.; Li, J.; Wang, N.; Yang, X.; Hamada, Y.; Li, Q.; Zheng, W.; Jiang, X. An on-chip model for investigating the interaction between neurons and cancer cells. Integr. Biol. 2016, 8, 359-367. [CrossRef]

196. Fan, Y.; Nguyen, D.T.; Akay, Y.; Xu, F.; Akay, M. Engineering a Brain Cancer Chip for High-throughput Drug Screening. Sci. Rep. 2016, 6, 25062. [CrossRef] [PubMed]

197. Osaki, T.; Shin, Y.; Sivathanu, V.; Campisi, M.; Kamm, R.D. In Vitro Microfluidic Models for Neurodegenerative Disorders. Adv. Healthc. Mater. 2018, 7, 1700489. [CrossRef] [PubMed]

198. Park, J.; Lee, B.K.; Jeong, G.S.; Hyun, J.K.; Lee, C.J.; Lee, S.H. Three-dimensional brain-on-a-chip with an interstitial level of flow and its application as an in vitro model of Alzheimer's disease. Lab Chip 2015, 15, 141-150. [CrossRef] [PubMed]

199. Osaki, T.; Uzel, S.G.; Kamm, R.D. Microphysiological 3D model of amyotrophic lateral sclerosis (ALS) from human iPS-derived muscle cells and optogenetic motor neurons. Sci. Adv. 2018, 4, eaat5847. [CrossRef]

200. Wilke, R.A.; Lin, D.W.; Roden, D.M.; Watkins, P.B.; Flockhart, D.; Zineh, I.; Giacomini, K.M.; Krauss, R.M. Identifying genetic risk factors for serious adverse drug reactions: Current progress and challenges. Nat. Rev. Drug Discov. 2007, 6, 904-916. [CrossRef]

201. Shinha, K.; Nihei, W.; Ono, T.; Nakazato, R.; Kimura, H. A pharmacokinetic-pharmacodynamic model based on multi-organ-on-achip for drug-drug interaction studies. Biomicrofluidics 2020, 14, 44108. [CrossRef]

202. Satoh, T.; Sugiura, S.; Shin, K.; Onuki-Nagasaki, R.; Ishida, S.; Kikuchi, K.; Kakiki, M.; Kanamori, T. A multi-throughput multi-organ-on-a-chip system on a plate formatted pneumatic pressure-driven medium circulation platform. Lab Chip 2018, 18, 115-125. [CrossRef]

203. Maschmeyer, I.; Lorenz, A.K.; Schimek, K.; Hasenberg, T.; Ramme, A.P.; Hübner, J.; Lindner, M.; Drewell, C.; Bauer, S.; Thomas, A.; et al. A four-organ-chip for interconnected long-term co-culture of human intestine, liver, skin and kidney equivalents. Lab Chip 2015, 15, 2688-2699. [CrossRef] [PubMed]

204. Zhao, Y.; Rafatian, N.; Wang, E.Y.; Wu, Q.; Lai, B.F.; Lu, R.X.; Savoji, H.; Radisic, M. Towards chamber specific heart-on-a-chip for drug testing applications. Adv. Drug Deliv. Rev. 2020, 165-166, 60-76. [CrossRef]

205. Oleaga, C.; Riu, A.; Rothemund, S.; Lavado, A.; McAleer, C.W.; Long, C.J.; Persaud, K.; Narasimhan, N.S.; Tran, M.; Roles, J.; et al. Investigation of the effect of hepatic metabolism on off-target cardiotoxicity in a multi-organ human-on-a-chip system. Biomaterials 2018, 182, 176-190. [CrossRef]

206. Lee, J.; Mehrotra, S.; Zare-Eelanjegh, E.; Rodrigues, R.O.; Akbarinejad, A.; Ge, D.; Amato, L.; Kiaee, K.; Fang, Y.C.; Rosenkranz, A.; et al. A Heart-Breast Cancer-on-a-Chip Platform for Disease Modeling and Monitoring of Cardiotoxicity Induced by Cancer Chemotherapy. Small 2020, 2004258. [CrossRef] [PubMed] 
207. Zhang, Y.S.; Aleman, J.; Shin, S.R.; Kilic, T.; Kim, D.; Shaegh, S.A.M.; Massa, S.; Riahi, R.; Chae, S.; Hu, N.; et al. Multisensorintegrated organs-on-chips platform for automated and continual in situ monitoring of organoid behaviors. Proc. Natl. Acad. Sci. USA 2017, 114, E2293-E2302. [CrossRef] [PubMed]

208. Maoz, B.M.; Herland, A.; Henry, O.Y.; Leineweber, W.D.; Yadid, M.; Doyle, J.; Mannix, R.; Kujala, V.J.; FitzGerald, E.A.; Parker, K.K.; et al. Organs-on-Chips with combined multi-electrode array and transepithelial electrical resistance measurement capabilities. Lab Chip 2017, 17, 2294-2302. [CrossRef] [PubMed]

209. Skardal, A.; Murphy, S.V.; Devarasetty, M.; Mead, I.; Kang, H.W.; Seol, Y.J.; Zhang, Y.S.; Shin, S.R.; Zhao, L.; Aleman, J.; et al. Multi-tissue interactions in an integrated three-tissue organ-on-a-chip platform. Sci. Rep. 2017, 7, 8837. [CrossRef]

210. Novak, R.; Ingram, M.; Marquez, S.; Das, D.; Delahanty, A.; Herland, A.; Maoz, B.M.; Jeanty, S.S.F.; Somayaji, M.R.; Burt, M.; et al. Robotic fluidic coupling and interrogation of multiple vascularized organ chips. Nat. Biomed. Eng. 2020, 4, 407-420. [CrossRef]

211. Petrosyan, A.; Cravedi, P.; Villani, V.; Angeletti, A.; Manrique, J.; Renieri, A.; de Filippo, R.E.; Perin, L.; Da Sacco, S. A glomerulus-on-a-chip to recapitulate the human glomerular filtration barrier. Nat. Commun. 2019, 10. [CrossRef]

212. Walter, F.R.; Valkai, S.; Kincses, A.; Petneházi, A.; Czeller, T.; Veszelka, S.; Ormos, P.; Deli, M.A.; Dér, A. A versatile lab-on-a-chip tool for modeling biological barriers. Sens. Actuators B Chem. 2016, 222, 1209-1219. [CrossRef]

213. Bhise, N.S.; Manoharan, V.; Massa, S.; Tamayol, A.; Ghaderi, M.; Miscuglio, M.; Lang, Q.; Zhang, Y.S.; Shin, S.R.; Calzone, G.; et al. A liver-on-a-chip platform with bioprinted hepatic spheroids. Biofabrication 2016, 8. [CrossRef]

214. Bauer, S.; Wennberg Huldt, C.; Kanebratt, K.P.; Durieux, I.; Gunne, D.; Andersson, S.; Ewart, L.; Haynes, W.G.; Maschmeyer, I.; Winter, A.; et al. Functional coupling of human pancreatic islets and liver spheroids on-a-chip: Towards a novel human ex vivo type 2 diabetes model. Sci. Rep. 2017, 7, 14620. [CrossRef]

215. Yu, F.; Deng, R.; Hao Tong, W.; Huan, L.; Chan Way, N.; Islambadhan, A.; Iliescu, C.; Yu, H. A perfusion incubator liver chip for 3D cell culture with application on chronic hepatotoxicity testing. Sci. Rep. 2017, 7, 14528. [CrossRef]

216. Lee, H.; Chae, S.; Kim, J.Y.; Han, W.; Kim, J.; Choi, Y.; Cho, D.W. Cell-printed 3D liver-on-a-chip possessing a liver microenvironment and biliary system. Biofabrication 2019, 11, 25001. [CrossRef]

217. Ma, L.D.; Wang, Y.T.; Wang, J.R.; Wu, J.L.; Meng, X.S.; Hu, P.; Mu, X.; Liang, Q.L.; Luo, G.A. Design and fabrication of a liver-on-a-chip platform for convenient, highly efficient, and safe: In situ perfusion culture of 3D hepatic spheroids. Lab Chip 2018, 18, 2547-2562. [CrossRef] [PubMed]

218. Schutgens, F.; Rookmaaker, M.B.; Margaritis, T.; Rios, A.; Ammerlaan, C.; Jansen, J.; Gijzen, L.; Vormann, M.; Vonk, A.; Viveen, M.; et al. Tubuloids derived from human adult kidney and urine for personalized disease modeling. Nat. Biotechnol. 2019, 37, 303-313. [CrossRef]

219. Chen, T.H.; Chen, J.S.; Ko, Y.C.; Chen, J.W.; Chu, H.Y.; Lu, C.S.; Chu, C.W.; Hsu, H.H.; Tseng, F.G. A microfluidic platform for investigating transmembrane pressure-induced glomerular leakage. Micromachines 2018, 9, 228. [CrossRef]

220. Vriend, J.; Nieskens, T.T.; Vormann, M.K.; van den Berge, B.T.; van den Heuvel, A.; Russel, F.G.; Suter-Dick, L.; Lanz, H.L.; Vulto, P.; Masereeuw, R.; et al. Screening of Drug-Transporter Interactions in a 3D Microfluidic Renal Proximal Tubule on a Chip. AAPS J. 2018, 20, 87. [CrossRef] [PubMed]

221. Kimura, H.; Nishikawa, M.; Yanagawa, N.; Nakamura, H.; Miyamoto, S.; Hamon, M.; Hauser, P.; Zhao, L.; Jo, O.D.; Komeya, M.; et al. Effect of fluid shear stress on in vitro cultured ureteric bud cells. Biomicrofluidics 2018, 12. [CrossRef] [PubMed]

222. Musah, S.; Dimitrakakis, N.; Camacho, D.M.; Church, G.M.; Ingber, D.E. Directed differentiation of human induced pluripotent stem cells into mature kidney podocytes and establishment of a Glomerulus Chip. Nat. Protoc. 2018, 13, 1662-1685. [CrossRef]

223. Yeste, J.; Martinez-Gimeno, L.; Illa, X.; Laborda, P.; Guimera, A.; Sanchez-Marin, J.P.; Villa, R.; Gimenez, I. A perfusion chamber for monitoring transepithelial $\mathrm{NaCl}$ transport in an in vitro model of the renal tubule. Biotechnol. Bioeng. 2018, 115, 1604-1613. [CrossRef]

224. Oleaga, C.; Lavado, A.; Riu, A.; Rothemund, S.; Carmona-Moran, C.A.; Persaud, K.; Yurko, A.; Lear, J.; Narasimhan, N.S.; Long, C.J.; et al. Long-Term Electrical and Mechanical Function Monitoring of a Human-on-a-Chip System. Adv. Funct. Mater. 2019, 29. [CrossRef]

225. Shin, S.R.; Zhang, Y.S.; Kim, D.J.; Manbohi, A.; Avci, H.; Silvestri, A.; Aleman, J.; Hu, N.; Kilic, T.; Keung, W.; et al. Aptamer-Based Microfluidic Electrochemical Biosensor for Monitoring Cell-Secreted Trace Cardiac Biomarkers. Anal. Chem. 2016, 88, 10019-10027. [CrossRef] [PubMed]

226. Lai, B.F.L.; Huyer, L.D.; Lu, R.X.Z.; Drecun, S.; Radisic, M.; Zhang, B. InVADE: Integrated Vasculature for Assessing Dynamic Events. Adv. Funct. Mater. 2017, 27, 1703524. [CrossRef]

227. Boudou, T.; Legant, W.R.; Mu, A.; Borochin, M.A.; Thavandiran, N.; Radisic, M.; Zandstra, P.W.; Epstein, J.A.; Margulies, K.B.; Chen, C.S. A microfabricated platform to measure and manipulate the mechanics of engineered cardiac microtissues. In Proceedings of the ASME 2012 Summer Bioengineering Conference, Fajardo, PR, USA, 20-23 July 2012; Volume 18, pp. 243-244. [CrossRef]

228. Kujala, V.J.; Pasqualini, F.S.; Goss, J.A.; Nawroth, J.C.; Parker, K.K. Laminar ventricular myocardium on a microelectrode array-based chip. J. Mater. Chem. B 2016, 4, 3534-3543. [CrossRef] [PubMed]

229. Oleaga, C.; Bernabini, C.; Smith, A.S.; Srinivasan, B.; Jackson, M.; McLamb, W.; Platt, V.; Bridges, R.; Cai, Y.; Santhanam, N.; et al. Multi-Organ toxicity demonstration in a functional human in vitro system composed of four organs. Sci. Rep. 2016, 6, 20030. [CrossRef] [PubMed] 
230. Inácio, P.M. Bioelectrical signal detection using conducting polymer electrodes and the displacement current method. IEEE Sens. J. 2017, 17, 3961-3966. [CrossRef]

231. Polacheck, W.J.; Kutys, M.L.; Yang, J.; Eyckmans, J.; Wu, Y.; Vasavada, H.; Hirschi, K.K.; Chen, C.S. A non-canonical Notch complex regulates adherens junctions and vascular barrier function. Nature 2017, 552, 258-262. [CrossRef]

232. Hasan, A.; Paul, A.; Memic, A.; Khademhosseini, A. A multilayered microfluidic blood vessel-like structure. Biomed. Microdevices 2015, 17. [CrossRef]

233. Wang, Y.I.; Abaci, H.E.; Shuler, M.L. Microfluidic blood-brain barrier model provides in vivo-like barrier properties for drug permeability screening. Biotechnol. Bioeng. 2017, 114, 184-194. [CrossRef]

234. Jeong, S.; Kim, S.; Buonocore, J.; Park, J.; Welsh, C.J.; Li, J.; Han, A. A three-dimensional arrayed microfluidic blood-brain barrier model with integrated electrical sensor array. IEEE Trans. Biomed. Eng. 2018, 65, 431-439. [CrossRef]

235. Papademetriou, I.; Vedula, E.; Charest, J.; Porter, T. Effect of flow on targeting and penetration of angiopep-decorated nanoparticles in a microfluidic model blood-brain barrier. PLOS ONE 2018, 13, e0205158. [CrossRef]

236. Xu, H.; Li, Z.; Yu, Y.; Sizdahkhani, S.; Ho, W.S.; Yin, F.; Wang, L.; Zhu, G.; Zhang, M.; Jiang, L. A dynamic in vivo-like organotypic blood-brain barrier model to probe metastatic brain tumors. Sci. Rep. 2016, 6, 1-12. [CrossRef]

237. Partyka, P.P.; Godsey, G.A.; Galie, J.R.; Kosciuk, M.C.; Acharya, N.K.; Nagele, R.G.; Galie, P.A. Mechanical stress regulates transport in a compliant 3D model of the blood-brain barrier. Biomaterials 2017, 115, 30-39. [CrossRef]

238. Marino, A.; Tricinci, O.; Battaglini, M.; Filippeschi, C.; Mattoli, V.; Sinibaldi, E.; Ciofani, G. A 3D Real-Scale, Biomimetic, and Biohybrid Model of the Blood-Brain Barrier Fabricated through Two-Photon Lithography. Small 2018, 14, 1702959. [CrossRef]

239. Kilic, O.; Pamies, D.; Lavell, E.; Schiapparelli, P.; Feng, Y.; Hartung, T.; Bal-Price, A.; Hogberg, H.T.; Quinones-Hinojosa, A.; Guerrero-Cazares, H. Brain-on-a-chip model enables analysis of human neuronal differentiation and chemotaxis. Lab. Chip 2016, 16, 4152-4162. [CrossRef] [PubMed]

240. Johnson, B.N.; Lancaster, K.Z.; Hogue, I.B.; Meng, F.; Kong, Y.L.; Enquist, L.W.; McAlpine, M.C. Correction: 3D printed nervous system on a chip. Lab. Chip 2016, 16, 1946. [CrossRef] [PubMed]

241. Akay, M.; Hite, J.; Avci, N.G.; Fan, Y.; Akay, Y.; Lu, G.; Zhu, J.J. Drug Screening of Human GBM Spheroids in Brain Cancer Chip. Sci. Rep. 2018, 8, 1-9. [CrossRef] [PubMed]

242. Zahavi, E.E.; Ionescu, A.; Gluska, S.; Gradus, T.; Ben-Yaakov, K.; Perlson, E. A compartmentalized microfluidic neuromuscular co-culture system reveals spatial aspects of GDNF functions. J. Cell. Sci. 2015, 15, 1241-1252. [CrossRef] 